\title{
A Hafted Halberd Excavated at Trecastell, Powys: from Undercurrent to Uptake - the Emergence and Contextualisation of Halberds in Wales and North-west Europe
}

\author{
By STUART NEEDHAM ${ }^{1}$
}

With contributions by MARY DAVIS ${ }^{2}$, ADAM GWILT ${ }^{2}$, MARK LODWICK ${ }^{2}$, PHIL PARKES ${ }^{3}$ and PETER REAVILL $^{4}$

Excavations at Trecastell, Powys, south Wales, in 2007 yielded a copper halberd complete with its haft-grip. This has major implications for the mode of hafting halberds, but the discovery has also prompted a reconsideration of insular halberds in their north-west European context. Understanding the relationships between different types of halberd and different regional groups continues to be hampered by the dearth of good dating evidence, but the creation of better classifications for British and Irish weapons and new radiocarbon dates on two examples, one being Trecastell, have allowed a new developmental scheme to be advanced.

The emergence of metal-headed halberds is considered more generally. While it is acknowledged that halberd-like implements pre-existed in other materials in some parts of Europe, it is argued that the appearance of metal-headed halberds depended on the transmission of a particular set of metallurgical and related skills. A new model for the vigorous uptake of halberds on a regional basis helps explain the patchiness and anachronism of halberd hotspots.

The Trecastell halberd adds to one of the significant concentrations of the weapon type in Britain and prompts a more general review of the earliest metalwork from Wales and the Marches. For the Chalcolithic, halberds are instrumental in identifying a major contrast in depositional behaviour; this contrast dissolves at the beginning of the Early Bronze Age when a 'new deposition ground' is established. The former is attributed to the existence of a regional group across much of the region for whom the halberd served as a cultural icon, while the latter may relate to the demise of this enshrined value for the halberd.

Keywords: halberd, Chalcolithic, Early Bronze Age, chronology, typology, hafted weapon, metalwork

Halberds have always fascinated archaeologists. Ó Ríordáin's classic paper of 1937 showed just how widely these axe-hafted dagger blades occurred in

${ }^{1}$ Langton Fold, North Lane, South Harting, GU21 5NW

Email: sbowman1@waitrose.com

${ }^{2}$ Amgueddfa Cymru - National Museum of Wales, Cathays

Park, Cardiff CF10 3NP

${ }^{3}$ Cardiff School of History, Archaeology \& Religion, Cardiff university, John Percival Building, Colum Drive, Cardiff CF10 3EU

${ }^{4}$ Finds Liaison Officer, Ludlow Library and Museum

Resource Centre, 7-9 Parkway Ludlow Shropshire SY8 2PG prehistoric Europe and served as a platform for subsequent pan-European studies aimed at understanding their dissemination and evolution (Lenerz-de Wilde 1991; Schuhmacher 2002; Brandherm 2004; Horn 2014) as well as significant regional studies (Butler 1963; Coles 1968-9; Harbison 1969; Schubart 1973; Gedl 1980; Savory 1980; Gallay 1981; Bianco Peroni 1994; Wüstemann 1995; Vandkilde 1996; O'Flaherty 2002; Brandherm 2003). O'Flaherty (1998) has published a thorough historical review of halberd studies Europewide. For many regions, however, contexts remain few and dating consequently problematic. As Lenerz-de 
Wilde observed (1991, 25), these problems have impeded any objective understanding of the continental-scale evolution of halberds.

The chronologies of regional sequences are however coming to be better understood. While Britain, Ireland, and the near continent lack any tradition of placing halberds in graves, the few documented or suspected hoards do offer valuable information. A further boost comes from two radiocarbon determinations from the hafts of halberds. Using this evidence in conjunction with a revised classification for Irish halberds and the first ever classification specific to the British corpus, it is possible to look afresh at this old, thorny issue.

The stimulus for the current research was the discovery of a halberd during the excavation by Cotswold Archaeology of a modest size ring-ditch found on the Brecon to Felindre gas pipe-line in southern Wales in 2007. While this find has been reported on in depth elsewhere (Needham forthcoming), its exceptional nature justifies a summary prior to embarking on wider discussions on halberd hafting, halberd evolution in north-west Europe and the social significance of halberds in Wales.

\section{PART I: AN EXCAVATED HALBERD FROM TRECASTELL, POWYS}

The site lies towards the head of the Usk Valley close to Trecastell (or Trecastle), a village some $15 \mathrm{~km}$ west of Brecon (Fig. 1; Cotswold Archaeology 2014). The upper Usk valley is hemmed in by mountain blocks - Black Mountain, the Brecon Beacons, Mynydd Eppynt, and the Black Mountains - and it is therefore an important east-west route through southern Wales, an alternative to the coastal plain of the Vale of Glamorgan. The ringditch lay on top of a ridge at a height of about $350 \mathrm{~m}$ OD (SN 85876 29166); the ridge forms a promontory between the River Usk to the south and, to the north, the headwaters of the River Gwydderig which flows north-westwards into the River Towi. The site therefore overlooks the lowest-lying crossing point between these two major valleys - Usk and Towi.

The halberd blade was lying horizontal a little beneath the ploughsoil approximately $1 \mathrm{~m}$ north-north-east of the centre of the ring-ditch of c. $9.2 \times 8.3 \mathrm{~m}$ internal diameter (Figs $2 \& 3$ ). The ditch was less than a metre wide and $0.3 \mathrm{~m}$ deep, its fill containing blocks of stone. It is possible it supported a light palisade enclosure, although no post-pipes were detected. There was no surviving evidence for a mound. The blade proved to overlie or sit within the top of the fill (context 38.17.057) of a pit (38.17.60) surviving about $1.3 \mathrm{~m}$ long, $0.9 \mathrm{~m}$ wide and $0.5 \mathrm{~m}$ deep (Fig. 3). The object lay fairly close to the northern edge of the pit, its tip pointing approximately east; if the halberd had been deposited with its handle intact (no stain was noted), this would have extended in a northerly direction which would have taken it beyond the pit's limits. Although the pit beneath would have been large enough to accommodate a sincedecayed crouched burial, the halberd was far too high to be considered a conventional grave accompaniment (Fig. 3). The halberd was lifted by one of the authors (MD) on a block of soil and was then transferred to Phil Parkes, conservator at the Department of Archaeology, Cardiff University, for cleaning and stabilisation.

The Trecastell halberd is a find of considerable importance for three main reasons. First, it is only the second from Britain to have been recovered during archaeological excavation (the other being from Eweford, East Lothian; Lelong \& MacGregor 2007, 235-6); this inevitably adds far more contextual information than exists for the many casual finds. Secondly, part of its wooden haft has survived and in surprisingly good condition given that this was not a waterlogged site; no such remains have been recorded before from Britain and only one haft is reported from Ireland (Carn, Co. Mayo; Raftery 1942). Thirdly, the presence of organic material offered the first opportunity to obtain a radiocarbon date in direct association with a halberd in northwestern Europe since the unhelpful result obtained from the Carn haft remains; a second halberd has since been dated (Bell 2014) and these have important implications for the still debated issue of the absolute chronology of halberds, as discussed further below.

\section{DESCRIPTION AND RECONSTRUCTION}

(Stuart Needham, Mary Davis, \& Phil Parkes)

The complete metal head of the halberd is present; however, the hafting-plate is concealed by the remains of a wooden haft (hereafter the haft-grip) attached by three thick rivets (Fig. 4; see Fig. 5 for terminology). The haft-grip has suffered in various ways and only extends a short distance beyond the limits of the metal haftingplate. Both the alignment of the wood grain and the morphology of blade and rivets make it clear that this object belongs to the halberd series, rather than to that of daggers. The faces of the halberd head and its upper and lower edges are defined in Figure 5; 'face 2' was 
S. Needham. EMERGENCE AND CONTEXTUALISATION OF HALBERDS IN WALES \& NW EUROPE
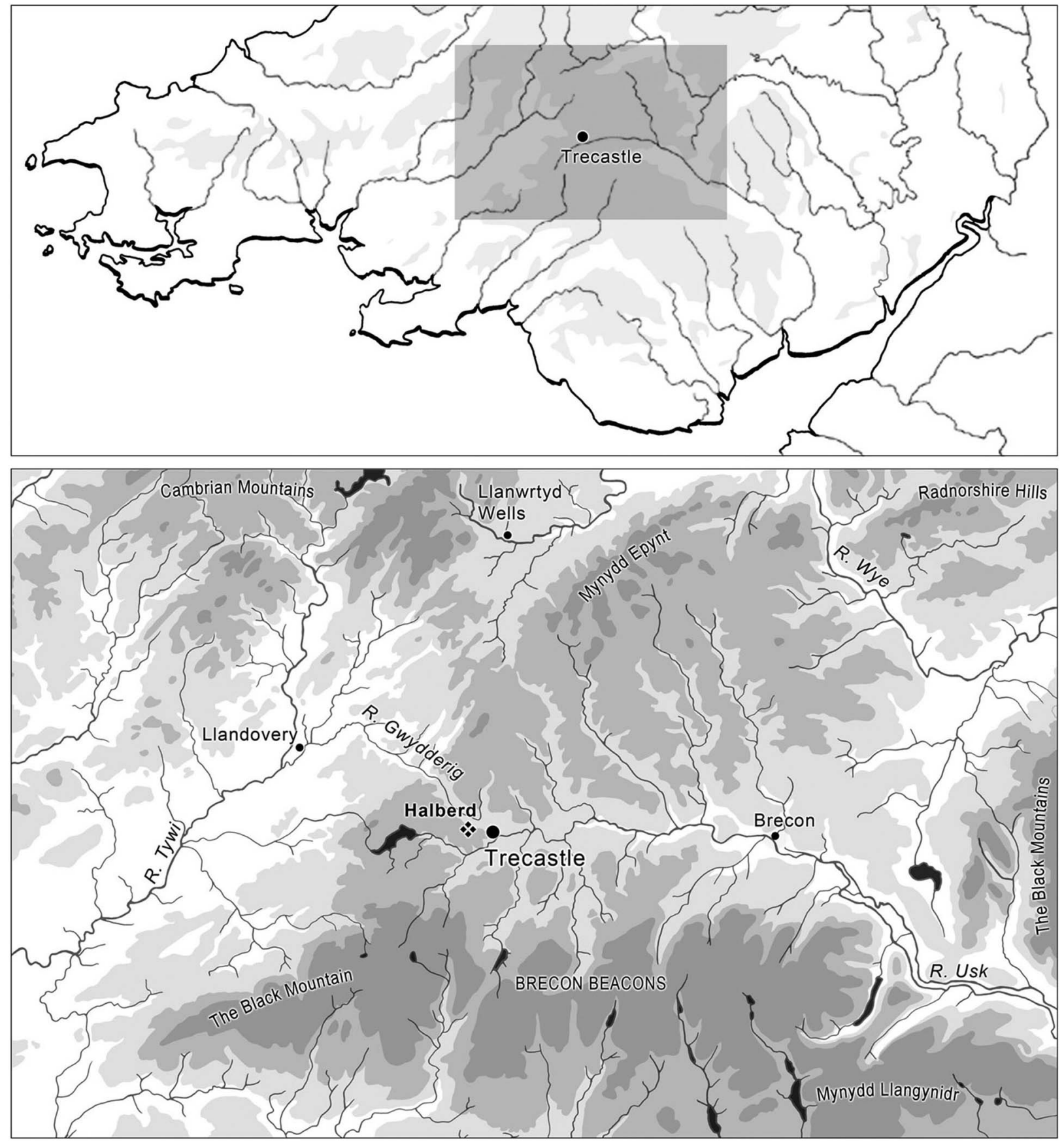

Fig. 1.

Location map for Trecastell, Powys, south Wales; drawing: Tony Daly, Amgueddfa Cymru-National Museum Wales (AC-NMW)

uppermost in the ground. A more complete description can be found in Needham et al. forthcoming.

The composite length of the object is $187 \mathrm{~mm}$ and its total weight $262.5 \mathrm{~g}$. The length of the metal head is
$185 \mathrm{~mm}$ (established from radiographs) of which $144 \mathrm{~mm}$ is the exposed blade. The maximum surviving width of the head is $76 \mathrm{~mm}$ and maximum thickness, $9.2 \mathrm{~mm}$. The midrib thins to $3.8 \mathrm{~mm}$ close to the tip. 


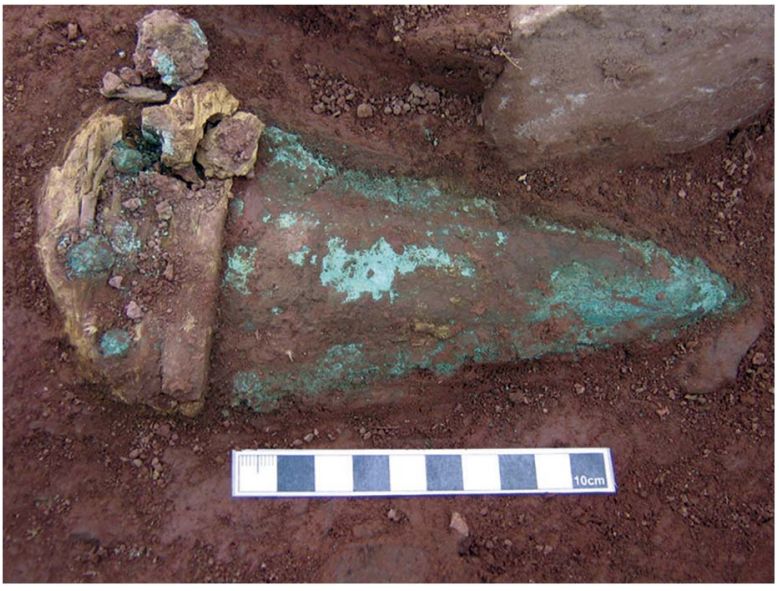

Fig. 2 .

The Trecastell halberd in situ; photo: Cotswold Archaeology

The extant lengths of the rivets range between $23.2 \mathrm{~mm}$ and $25.3 \mathrm{~mm}$. The haft-grip has a maximum length (with the grain) of $85.3 \mathrm{~mm}$, a maximum breadth of $44.0 \mathrm{~mm}$ (face 2) and maximum thickness of $21 \mathrm{~mm}$.

The object was buried in an adverse environment for copper and its alloys (no $\mathrm{pH}$ measurement was undertaken). The penetration of surface corrosion had (as is usually the case) a disproportionate effect on the thin parts - cutting edges and the butt - because it penetrates from both sides and meets in the middle leaving no solid metal (supplementary material Fig. S1: note that, hereafter, figure, table and appendix numbers prefixed by ' $S$ ' refer to the supplementary online material). Consequently, virtually none of the original cutting edges is intact.

The haft-grip and upward facing rivet heads had evidently been scraped by an excavation tool, possibly during machine stripping. The haft-grip is now badly split and, although this may be due to earlier decay, photographs of the object in situ make it clear that the wood alongside the butt has drifted away from the blade since recovery skewing the lower rivet in the process (Figs $2 \& 4$ ). Another aspect of damage is seen in the rotation of the butt part of the haft-grip as seen in profile; the detailed profile radiograph (Fig. 6) shows the acutely tapering butt end of the socket in the wood turned by approximately $14^{\circ}$ to the axis through the blade. The direction of rotation was downwards in the ground. The rivets were also pushed downwards so that they now project much further on face 1 than on face 2. It may have been this trauma which also caused the upper rivet to shear mid-shank, again visible in Figure 6 . The butt side of the haftingplate, which would have been thin metal, is consequently badly fragmented.

\section{The state of the object on deposition}

While the butt-end rotation described might have occurred during excavation, there are grounds for thinking it happened much earlier in the object's burial history. The radiographs show a marked discontinuity in metal density from inside the rivet emplacements to outside (Fig. 7), whereas one might have expected a more gradual reduction in density, as is the case between the midrib and blade edges. It is possible therefore that this fracturing occurred early enough for there subsequently to have been significant differential decay - the thin and broken-up areas having been much more susceptible to accelerated decay than was the thicker, still-intact area between the rivets.

Another piece of evidence implies ancient damage. While very little of the edges survive on the halberd's blade, there is a near-intact stretch, $8 \mathrm{~mm}$ long and fairly close to the tip on the upper edge, yet this is bent down towards face 1 by about $30^{\circ}$. This must be precorrosion damage, otherwise it would undoubtedly have snapped off and crumbled. This is not just a notch formed by having been struck by another sharp edge and might imply more systematic decommissioning. It is noteworthy that an adjacent stretch of edge seems to have been bent in the opposite direction. Despite the poor condition of the Trecastell halberd, there are thus grounds for suspecting it had suffered some trauma prior to or during deposition.

\section{Metal head form (Fig. 8)}

The process of reconstructing the original form of the head is covered in full in Needham forthcoming. In situ photographs show a dull greenish-grey stain in some of the surrounding soil, especially along the lower blade edge; this may approximate to the original position (Fig. 2), but any small-scale asymmetries or curvature cannot be determined. The blade has a strong broad midrib, $37.5 \mathrm{~mm}$ wide at its head and gently convex in cross-section with sides sloping down to an angle where they meet the blade wings. The midrib stands proud of the wings by some $3 \mathrm{~mm}$ on either face. Viewed in long section, it is remarkably constant in thickness (8.5-9.2 mm) over a length of $90 \mathrm{~mm}$ (Fig. 9). Close to the hafting line it begins to taper steadily, ultimately coming to a very thin butt (Fig. 6). 


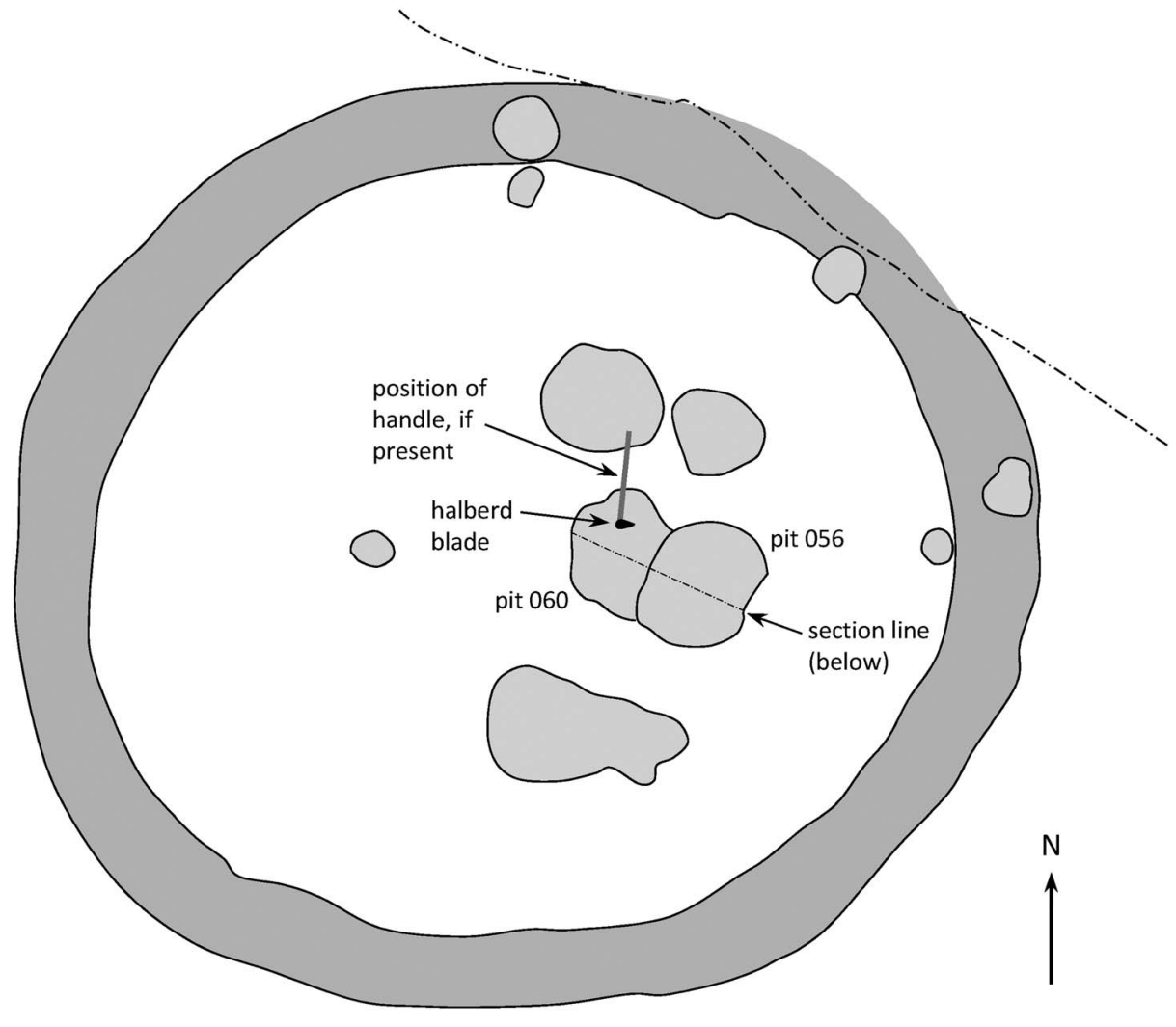

$5 m$

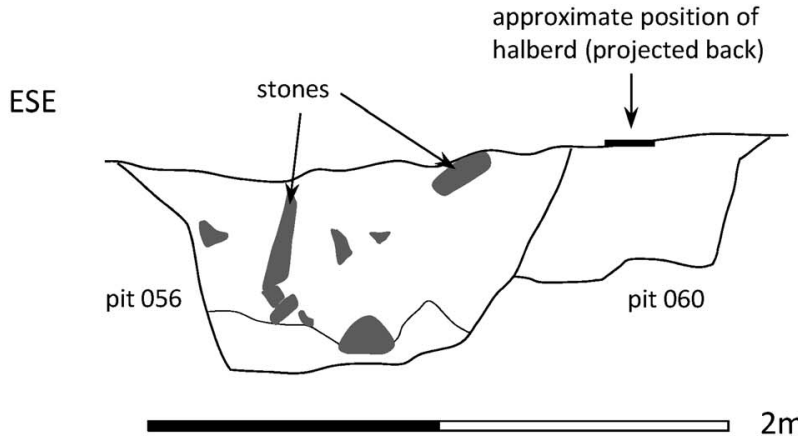

WNW

Fig. 3.

Simplified plan of the ring-ditch and associated features excavated at Trecastell, with section drawing through the pit or grave beneath the halberd; the position of the halberd has been projected onto the section; drawings: Stuart Needham after Daniel Bashford, Cotswold Archaeology

The intact but bent stretch of cutting edge described above has on the outer, stretched face hints of two facets running parallel to the edge (Fig. 10); these might be vestiges of former edge-backing bevels. The butt is concealed inside the haft-grip and its line has to be deduced from the face-view radiographs. Despite the sudden change in metal density at the line of the rivets, a number of thin platelets of metal are visible in the butt zone through a longitudinal crack in the back of the haft-grip (Fig. 11). Although very thin, highly corroded and often disoriented, these platelets approach to within a couple of millimetres of the 

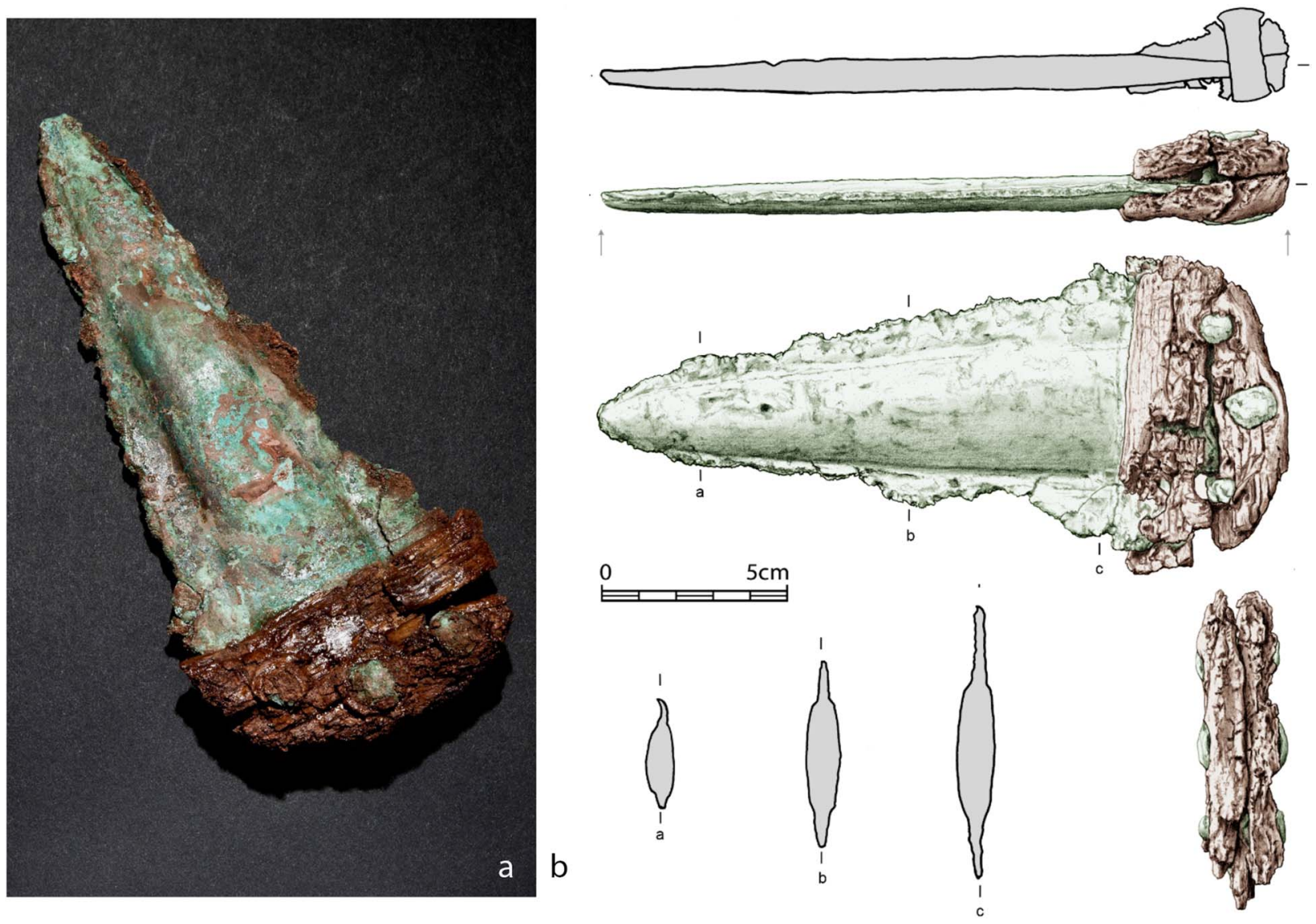

Fig. 4.

The Trecastell halberd after cleaning and conservation: copper head and wooden (Pomoideae) haft-grip; a) face 1; photo: Robin Maggs, AC-NMW; b) face 2, side views and cross-sections; scale 50\%; drawing: Tony Daly, AC-NMW

surviving haft back and seem to have been set within a slight but neatly cut recess in the wood. Enhancement of radiographs picks out a consistent and neat butt-line from these rather ephemeral traces (Fig. 7); it was moderately deeply arched with a tri-lobate tendency. The exact shape of the shoulders is trickier to establish, but careful evaluation suggests there was likely to have been a distinct step inwards from blade to hafting plate.

\section{Rivets}

The rivets are of thick 'plug' form but have been differentially eroded by corrosion; this is most acute in the lower rivet which is markedly atrophied towards face 2. Consequently surviving head diameters range widely up to a maximum of $14 \mathrm{~mm}$ (Needham forthcoming, table 1). Where the shanks are visible through cracks in the wood, hints of the longitudinal faceting can be seen. The diameter of one rivet shank can be estimated from the radiographs as around $9 \mathrm{~mm}$. Even the better preserved heads may have been reduced by corrosion to judge from annular impressions in the wood encircling two of the rivet heads on face 1 (Fig. 12). That around the central rivet has a diameter of $17.5 \mathrm{~mm}$, while one of about $14 \mathrm{~mm}$ diameter encircles the upper rivet. These light grooves may have been impressed by the rim of the rivet head during clenching or, alternatively, could have been incidentally formed by the edges of an abrading tool used in a rotary action to finish the rivet heads after clenching.

\section{Angle of mounting}

Because of the movement of the haft-grip relative to the metal head, the angle at which the latter was mounted has to be deduced from haft-lines visible in 


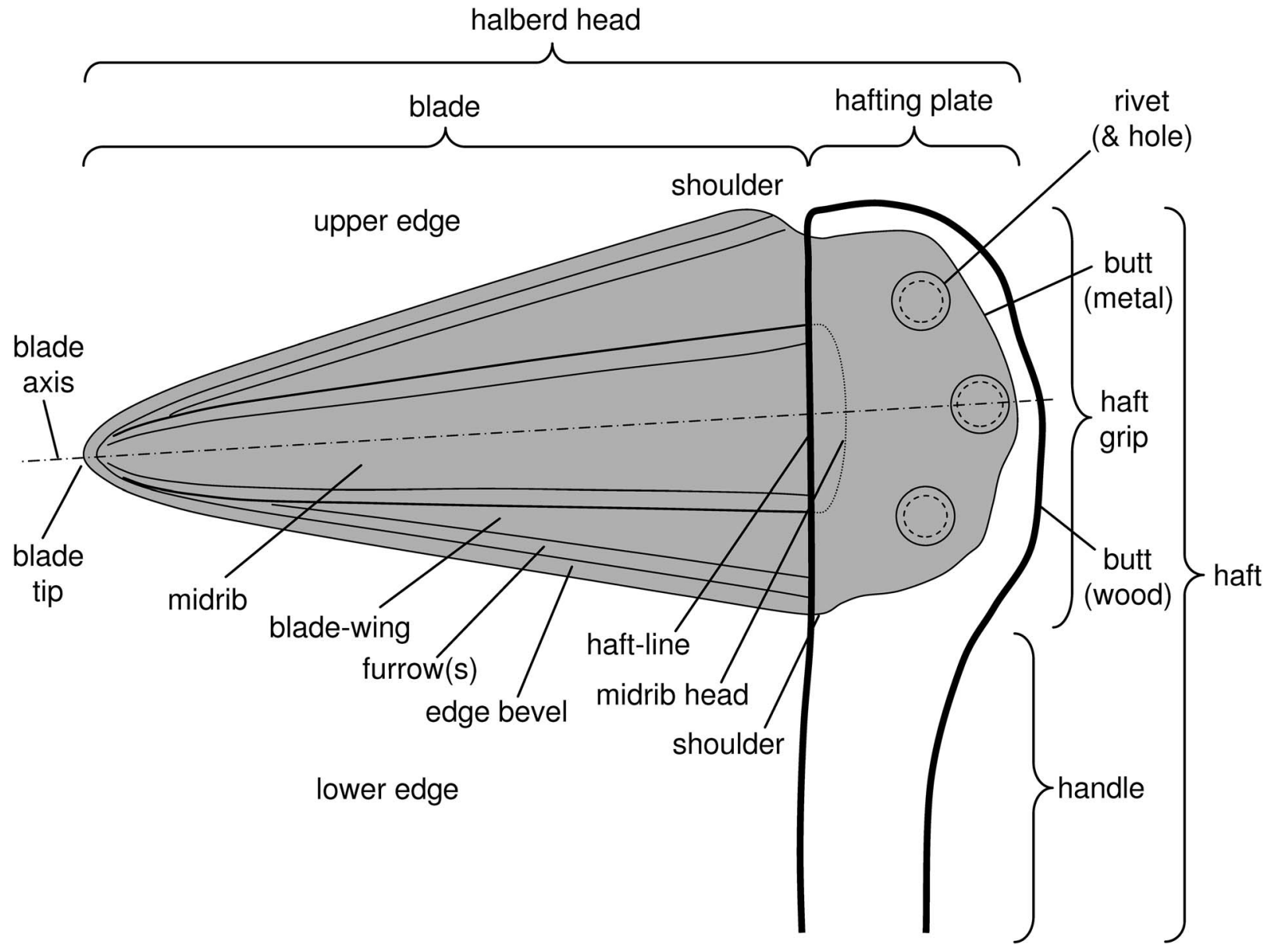

Fig. 5 .

The main features of the halberd and the terminology used; note that the edge features are uncertain on the Trecastell example and that the handle part of the haft is conjectural; drawing: Stuart Needham

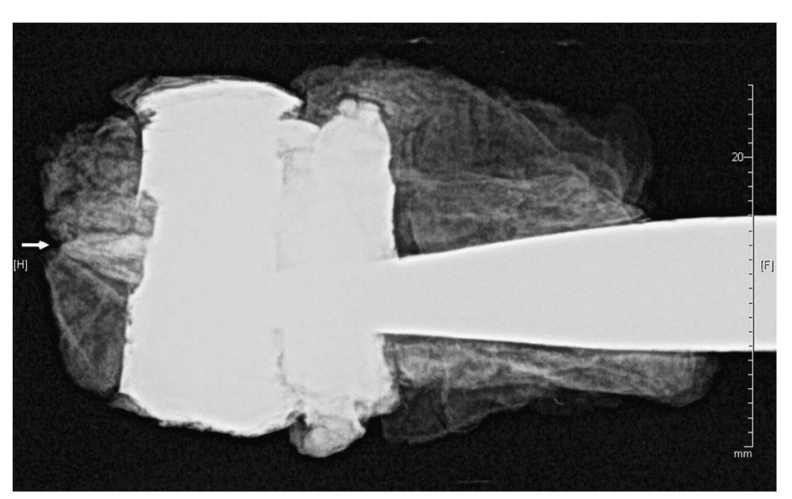

Fig. 6.

Radiograph of the haft-end of the halberd in profile view; image: Mary Davis the patinated surface in conjunction with a line drawn between the upper and lower rivet positions. Both are approximately $2^{\circ}$ off the perpendicular to the long axis through the midrib; this axis itself, however, passes through the central rivet hole (Fig. 5). The mounted blade would have tilted a little downwards and although the angle sounds small, it is actually very obvious to the casual observer in a hafted halberd (see Fig. 18).

\section{The wooden haft-grip}

Most of the haft-grip survives in a somewhat desiccated state. Nevertheless, Rowena Gale (in Needham forthcoming) was able to conclude that the wood 

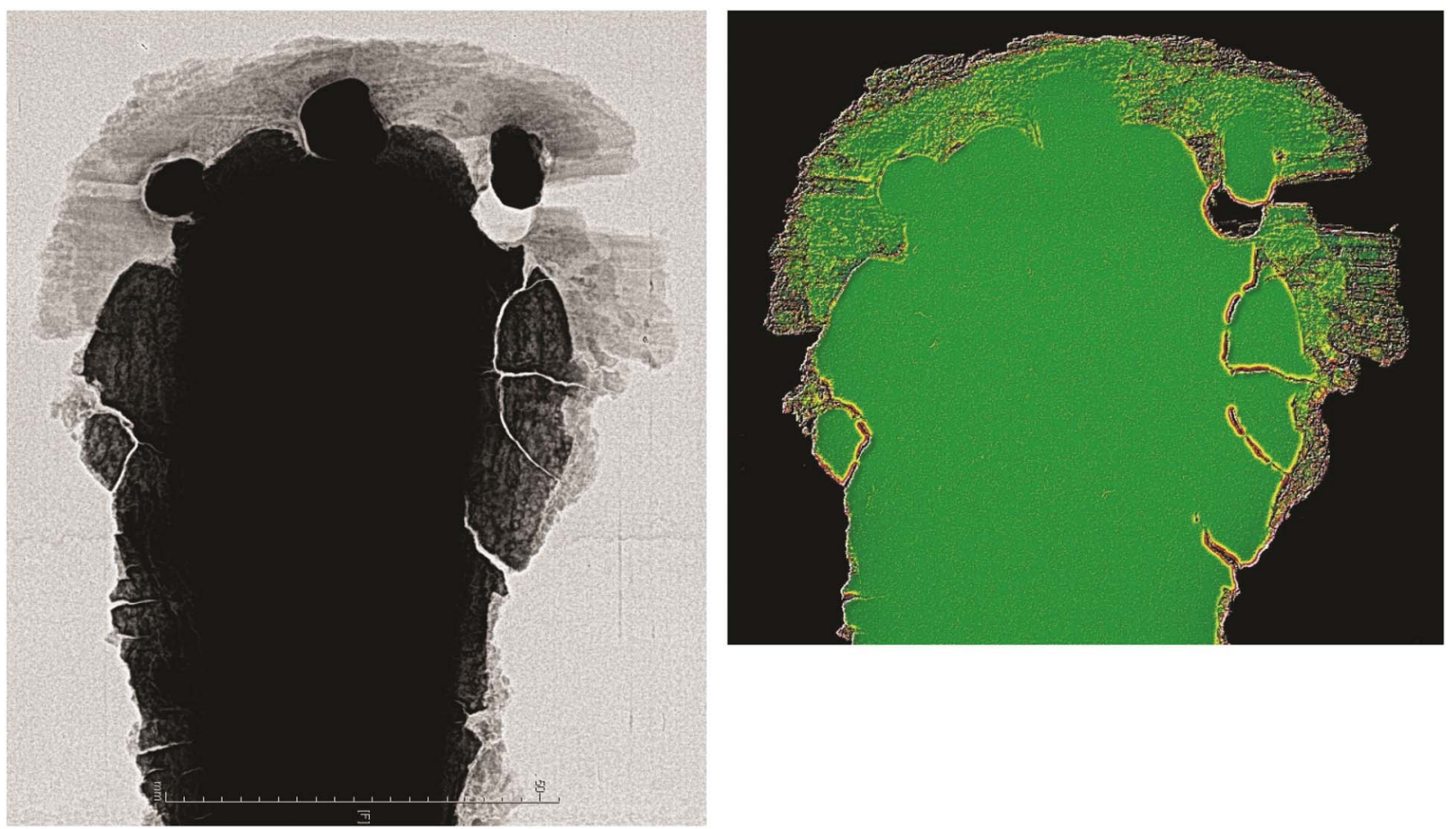

Fig. 7.

Radiograph of the haft-end of the halberd in face view; at first sight the marked change in metal density from inside to outside the rivet line (a) suggests, incorrectly, that this was the original butt; this is instead visible as a fainter density boundary further towards the butt showing more clearly in (b); images: Mary Davis
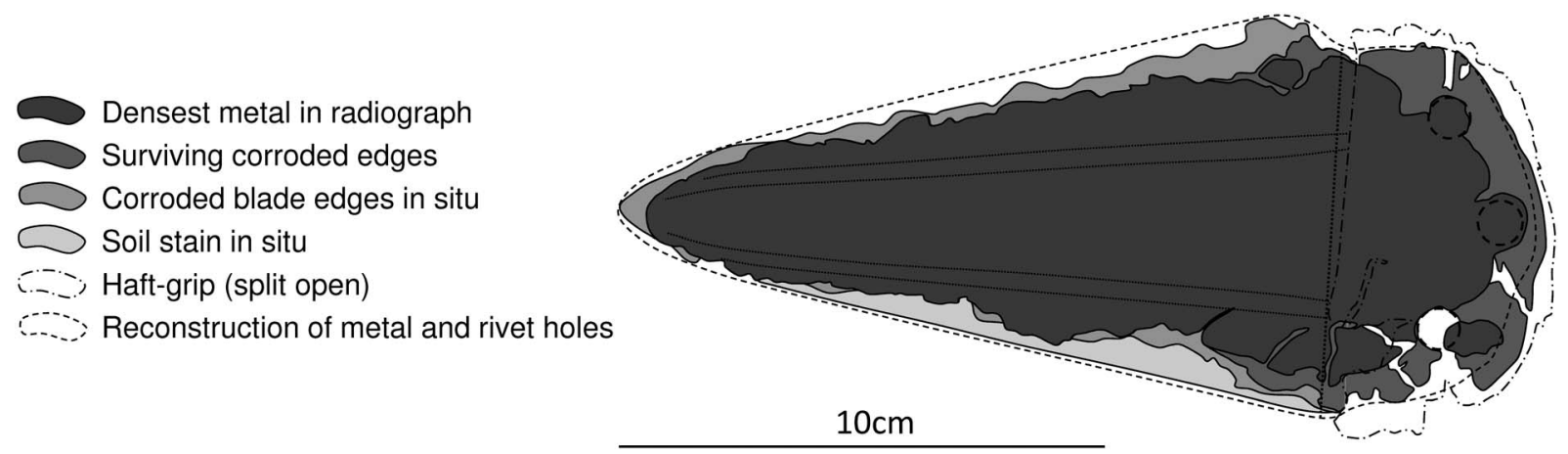

Fig. 8 .

Reconstruction of the metal head of the halberd using radiographs and in situ photographs; in the reconstruction outline (dashed) one side of the butt has been shifted to compensate for the split; scale 50\%; drawing: Stuart Needham

structure was consistent with that of the Pomoideae, a subfamily of the Rosaceae. Members of this group include Malus sp. (apple), Pyrus sp. (pear), Crataegus sp. (hawthorn) and Sorbus sp. (rowan, whitebeam, and service) ... The wood of these species is hard and closegrained and has, traditionally, been used for tool handles'. It has not been possible to ascertain the anatomy of the wood used.

The better preserved features are found on face 2, uppermost in the ground. The haft-line, except at one end which is missing, follows an almost straight line; minimal wavering is probably due to warping during 


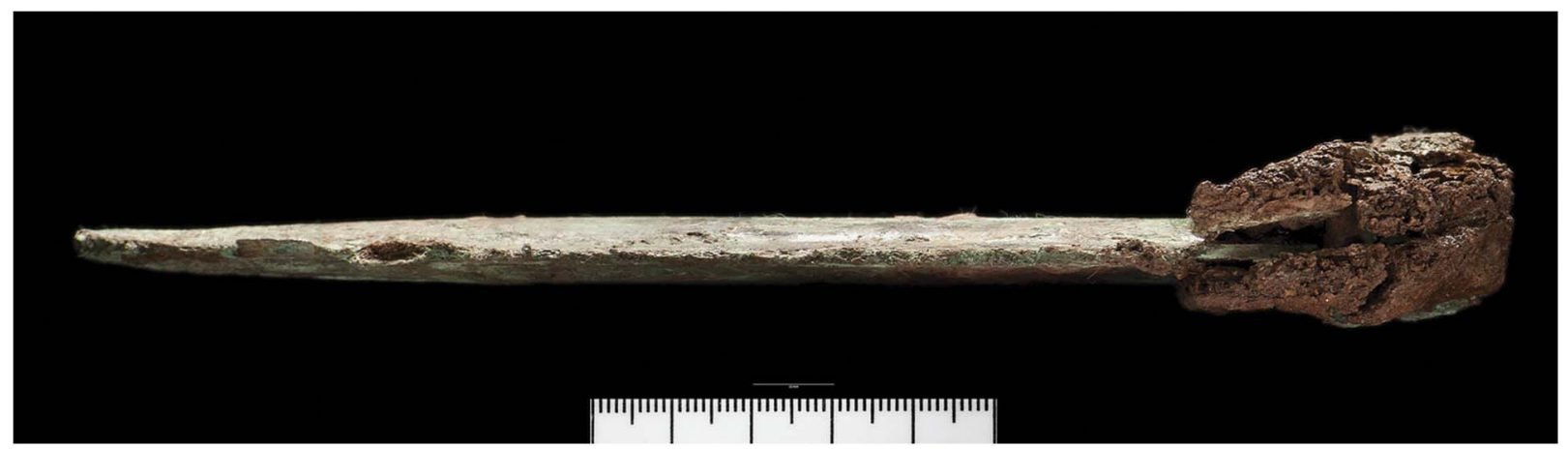

Fig. 9.

Full object in profile view from the top; photo: Robin Maggs, AC-NMW

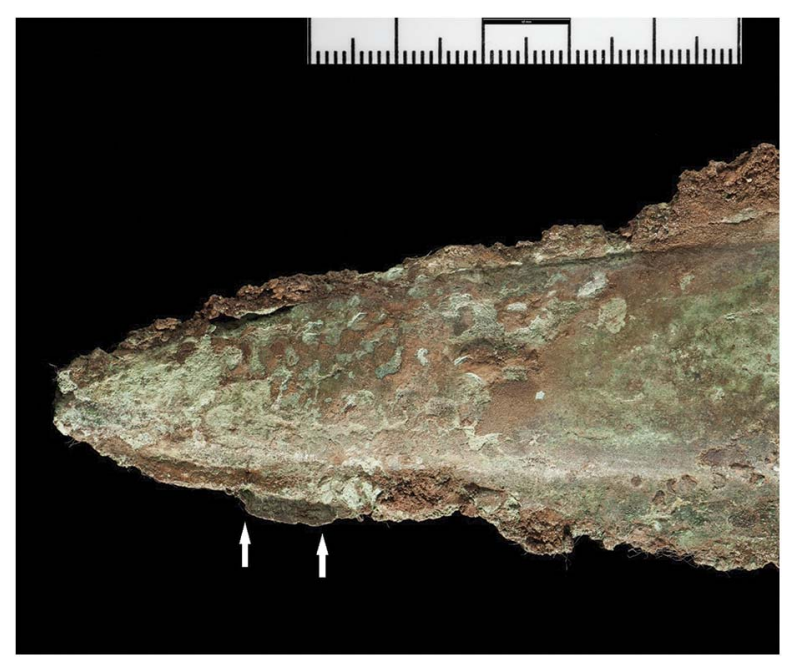

Fig. 10.

Detail of the most intact stretch of cutting edge (arrowed); this is only $8 \mathrm{~mm}$ long and had been bent by approximately $30^{\circ}$ in antiquity; photo: Robin Maggs, AC-NMW

burial. Currently this leading edge stands proud of the midrib by up to $4 \mathrm{~mm}$, its top edge being rounded, potentially the original form (Fig. 13). Between the strip defining the haft-line and the rivets the wood has a more fragmented surface including some major cracks. However, a more unbroken surface resumes towards the butt behind the upper and central rivets. The surface of the grip here is essentially flat, but then gives way to a neat butt chamfer which follows a sinuous line respecting the rivet heads; the line is clear behind the upper and central rivets and is still discernible in the cracked wood behind the lower one (Figs 4b \& 14).

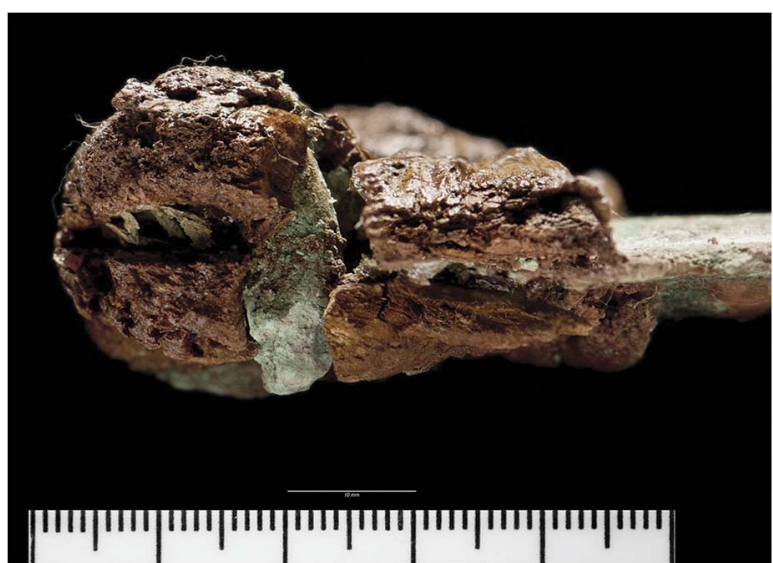

Fig. 11.

Lower side of the haft-grip showing corroded and fragmented butt of the metal head through a split; photo: Robin Maggs, AC-NMW

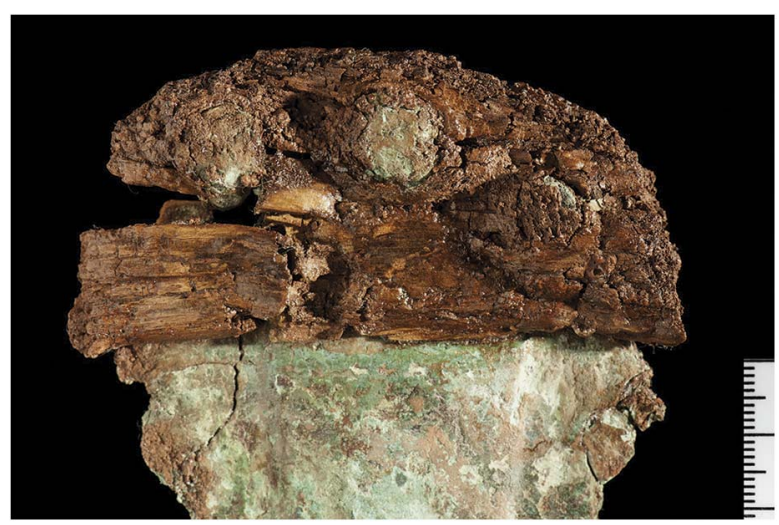

Fig. 12.

Haft-grip face 1 showing annular impressions in the wood encircling the rivet remains; photo: Robin Maggs, AC-NMW 


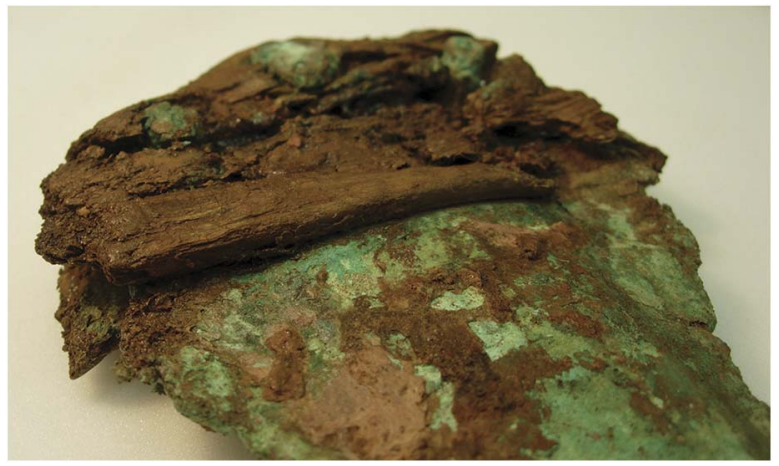

Fig. 13.

Oblique view of the haft-line on face 2; photo: Stuart Needham

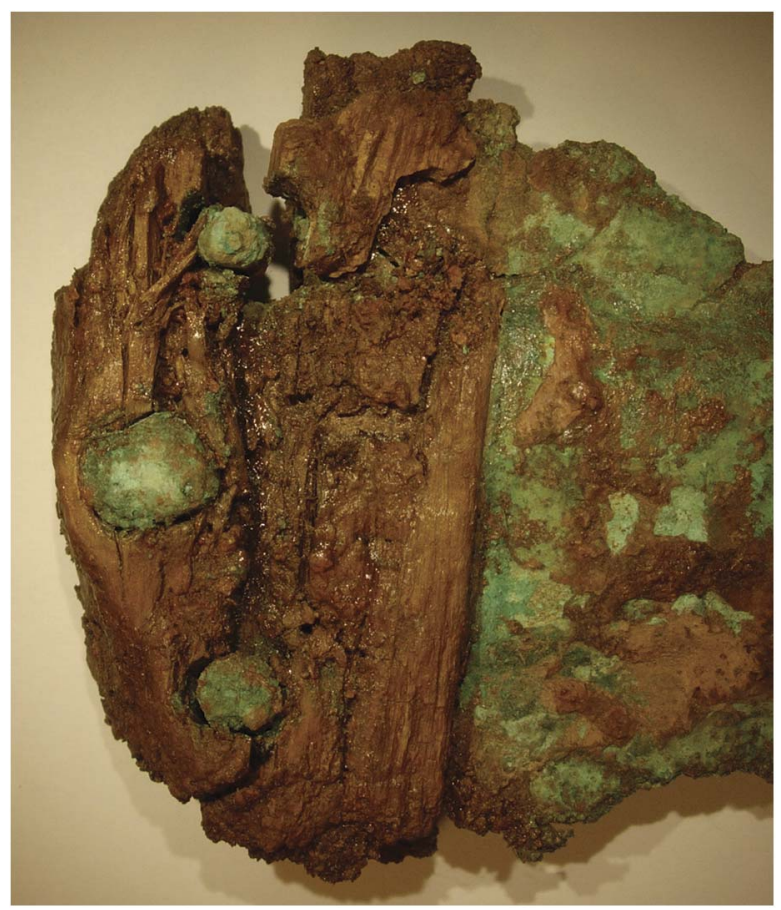

Fig. 14.

Haft-grip face 2, showing sinuous chamfer along the butt; photo: Stuart Needham

On face 1 the haft-line is interrupted by cracks and indents and the central part of the face, as far as the haft-line, is scalloped suggesting that a large chip of wood had been removed in antiquity or had decayed in the ground (Fig. 15). The haft-line edge rises to either side of the scalloped area and is, at a maximum, $8 \mathrm{~mm}$ proud of the blade in front of the lower rivet.

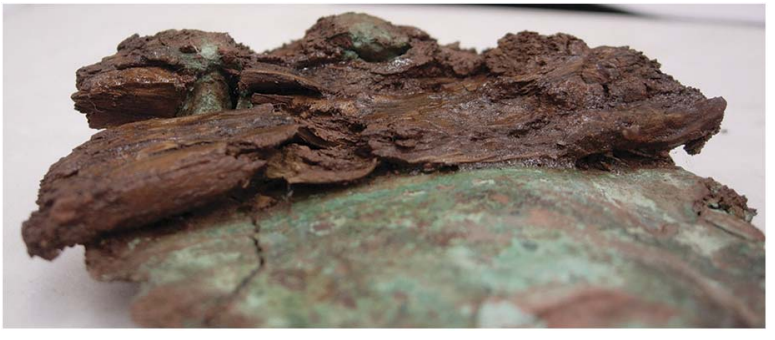

Fig. 15.

Oblique view of the haft-line on face 1; photo: Stuart Needham

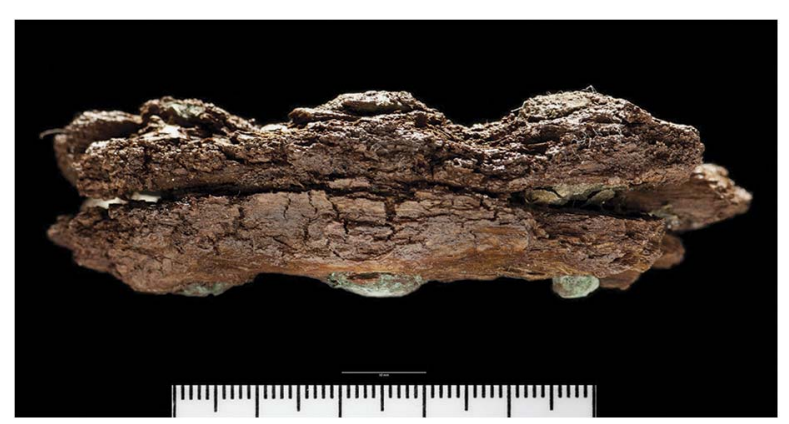

Fig. 16.

Butt view of the haft-grip showing the longitudinal split; photo: Robin Maggs, AC-NMW

Desiccation has caused rather cuboid fracturing towards the butt and this has obscured any original morphology. Curiously though, this face is the better for showing the annular impressions around the rivet heads noted above.

The side of the haft-grip deduced to be the top of the haft (Figs 4b \& 5) has a slightly saw-tooth outline relating to the transverse grain. Nevertheless, particularly when viewed vertically from face 1 , the general trend of the line suggests a continuous convex curve. The opposite side is much more irregular and is also where the major split enters; this is deduced to be the side from which the handle extended. The haft butt viewed end on shows a central fissure running its full length (Fig. 16); while theoretically this might be a subsequent split along the grain of the wood, its straight line and coincidence with the thin metal butt of the hafting-plate allows it to have been an original join between two plates of wood. This is actually an obvious solution to the problem of creating a socket for the very thin hafting-plate, as discussed further below. 


\section{S. Needham. EMERGENCE AND CONTEXTUALISATION OF HALbERDS IN WALES \& NW EUROPE}

\section{Radiocarbon determination}

At an early stage in the post-excavation process a sample of the haft-grip was submitted for radiocarbon assay. The result returned was: $3860 \pm 40 \mathrm{BP}$ (Beta-240338), calibrating to 2470-2200 cal вс (OxCal v4.2; end-points rounded outwards to nearest ten years)

Although it is possible that the rings in the haft were old wood, younger rings all having been trimmed off, the various species options are unlikely to have produced a large discrepancy between the date of the growth rings and the date of hafting the halberd. It had been hoped to obtain at least one additional radiocarbon determination, but unfortunately the wood had all been consolidated by the time the present study began and a small sample submitted to the Oxford Laboratory yielded insufficient carbon for dating.

The large pit or grave beneath the halberd remains undated, but two other contexts on the site have yielded very comparable radiocarbon ages: a second large pit close by to the north (38.17.064) and the enclosing ring-ditch (38.17.011) (Griffiths in Cotswold Archaeology 2014). Together these suggest an early phase dating to the Chalcolithic comprising an enclosure around at least two large pits or graves and the halberd deposit. Further activity on the site, including cremation burials, appears to follow a significant interlude of three or more centuries (ibid.).

\section{Metal composition}

Analysis was carried out using a CamScan Maxim 2040 scanning electron microscope (SEM) fitted with an Oxford Instruments wavelength dispersive spectrometer (WDS) and ISIS energy dispersive spectrometer (EDS). Operating conditions employed a $30^{\circ}$ take-off angle, and a $20 \mathrm{kV}$ accelerating voltage. Full details of the method are given by M. Davis in Needham forthcoming.

Three samples were taken from the halberd using a $0.9 \mathrm{~mm}$ drill bit: one from close to the haft-grip, one from near the tip and the third from one of the rivets. These were mounted in resin, polished flat and carbon coated. Each sample was analysed at least three times both by WDS and EDS, and the results were averaged for each sample (Table 1). Most readings were generally consistent; the exception was antimony, which appeared to be very unevenly dispersed within the metal (e.g. results from the same drilled sample varied between $0.05 \%$ and $0.294 \%$ ).

The analysis confirms that both blade and rivet are of unalloyed copper; no tin was detected. The principal minor elements present in both are arsenic (As), silver ( $\mathrm{Ag}$ ) and antimony ( $\mathrm{Sb}$ ), arsenic being by far the largest impurity, and it is significant that no nickel was detected. Although the antimony level in the blade is at the low end of the distribution, this impurity signature still conforms well to 'A-metal' (Needham 2002, fig. 4) and it can be taken with some confidence that the metal derives from the Ross Island copper mines, Co Kerry (O’Brien 2004).

\section{PART II: HAFTING, CLASSIFICATION \& DISSEMINATION OF HALBERDS}

\section{THE HAFTING OF HALBERDS}

Direct evidence for the form of halberd hafts in northwest Europe is very slight indeed and there are some important implications to be drawn from the haft-grip surviving at Trecastell. The only haft reported to have survived otherwise was that on the celebrated Carn find, Co. Mayo (Appendix S3, Cat. No. 44; Raftery 1942), while further evidence for the form of a haft comes from a depiction of a halberd at Ri Cruin, Argyll \& Bute (Needham \& Cowie 2012). Ri Cruin is unique in north-west Europe, but plenty of rock carvings further afield - in Scandinavia, the Alps, Iberia, and Morocco - show hafted halberds (eg, Chernorkian 1988; Brandherm 2003; O'Flaherty 2007; Horn 2014). Another type of evidence comes only from northern Europe, where metal-hafted halberds were produced. These are thought to be skeuomorphs of wooden-hafted examples from the same region (Wüstemann 1995; Gedl 1980); some of

TABLE 1: THE RESULTS OF ANALYSIS OF THE TRECASTELL HALBERD

\begin{tabular}{lcccccccccccc}
\hline & $\mathrm{Fe}$ & $\mathrm{Co}$ & $\mathrm{N} i$ & $\mathrm{Cu}$ & $\mathrm{Zn}$ & $\mathrm{As}$ & $\mathrm{Sb}$ & $\mathrm{Sn}$ & $\mathrm{Ag}$ & $\mathrm{Bi}$ & $\mathrm{Pb}$ & $\mathrm{Au}$ \\
\hline Blade near tip & 0.01 & 0.01 & 0 & 94.36 & 0.02 & 4.71 & 0.13 & 0 & 0.25 & 0 & 0.02 & 0 \\
Blade near haft & 0.02 & 0 & 0 & 95.19 & 0.07 & 4.23 & 0.08 & 0 & 0.27 & 0.02 & 0 & 0 \\
Rivet & 0.01 & 0.01 & 0 & 94.83 & 0.08 & 4.43 & 0.28 & 0 & 0.21 & 0 & 0.01 & 0 \\
\hline
\end{tabular}

All results are by WDS, except for copper, by EDS 
the latter had metal bindings around their wooden hafts. All this more remote evidence can be instructive on the principles of halberd hafting, but care needs to be exercised in transferring specific modes crossculturally.

The insular evidence is most likely to be relevant to Trecastell, and vice versa. Ostensibly the most intact haft was that from Carn, found 40 inches $(1.02 \mathrm{~m})$ below the already reduced surface of a bog (Raftery 1942). Its appearance is now well enshrined in the literature through Harbison's illustration (1969, fig. 4B) of a modern 'copy', apparently all that now survives (Fig. 17; Mary Cahill, pers. comm.). The copy has generally been taken to be a faithful representation of a mounted Irish halberd. However, archival material in the National Museum of Ireland suggests it should not be accepted as such (Needham forthcoming); the original handle reached archaeological attention only as 'shrivelled remains', whereas someone involved in the find at the time described the haft to be 'as thick as the handle of a pick-axe' (Timoney 1970, 5 fn 9).

While the handle of the Trecastell haft has not survived, it is nevertheless clear from the shaping of the butt and torn wood fibres at the bottom that it entered the grip in line with the front and thus the butt formed a significant backward projection (Fig. 18). This resembles the shape seen at Ri Cruin, as well as in some of the Continental halberd carvings (Fig. 19). Examples of butt-projecting halberds in the continental carvings are probably outnumbered by those without (eg, Chernorkian 1988; Brandherm 2003; Horn 2014) and some regions have depictions of both. Despite the potential problems of schematisation in these carvings, it is worth observing that butt projection would be less likely where hafting-plates and rivet lines are shallow, as is the case for many Mediterranean styles of halberd. A more consistent pattern is evident amongst the eastern German and Polish metalhafted halberds (Fig. 21; Wüstemann 1995, pls 12-21; Gedl 1980, pls 8-10); these universally have projecting butts, albeit of varied shapes and sizes.

The second point to draw from the Trecastell haft remains is that the grip effectively comprises two separate plates of wood which sandwich the metal hafting-plate. This should not be too surprising since the hafting-plates of halberd heads are not only fairly deep (along the longitudinal axis), but are also rather thin and it would be incredibly difficult to carve out a recess in a single piece of wood that fitted snugly
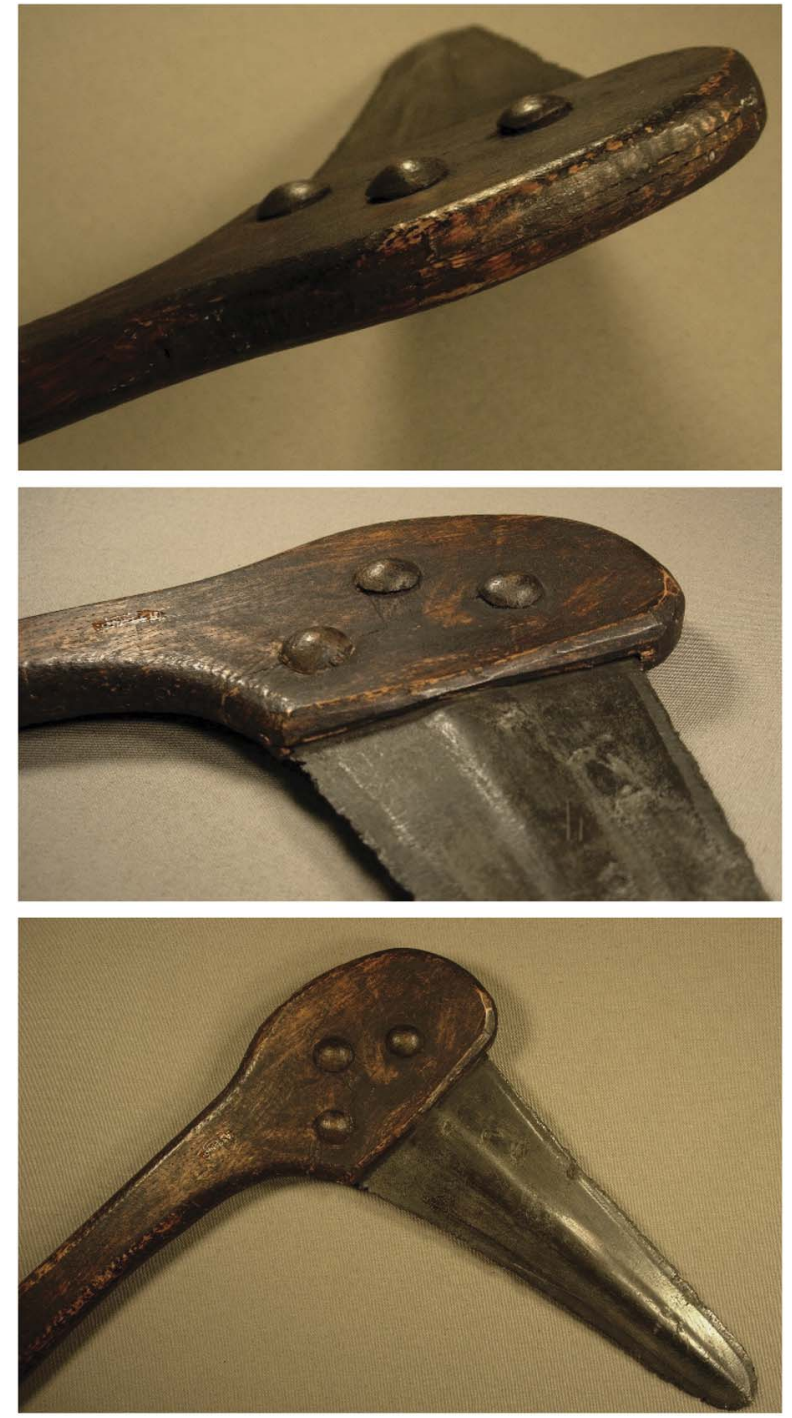

Fig. 17.

The modern 'copy' of halberd haft from Carn, Co. Mayo; object in the National Museum of Ireland; photos: Stuart Needham

round the hafting-plate. Wedging the blade into a larger recess might be one option, but a split grip instead allows two complementary half-recesses to be accurately carved in both inner faces before the two halves are brought back together and clamped by the rivets. The function of the rivets in this arrangement would thus be twofold; securing the blade against twisting and wrenching, but at the same time tightly clamping the 'sandwich'. This arrangement is actually not radically different from that used for butt-riveted 


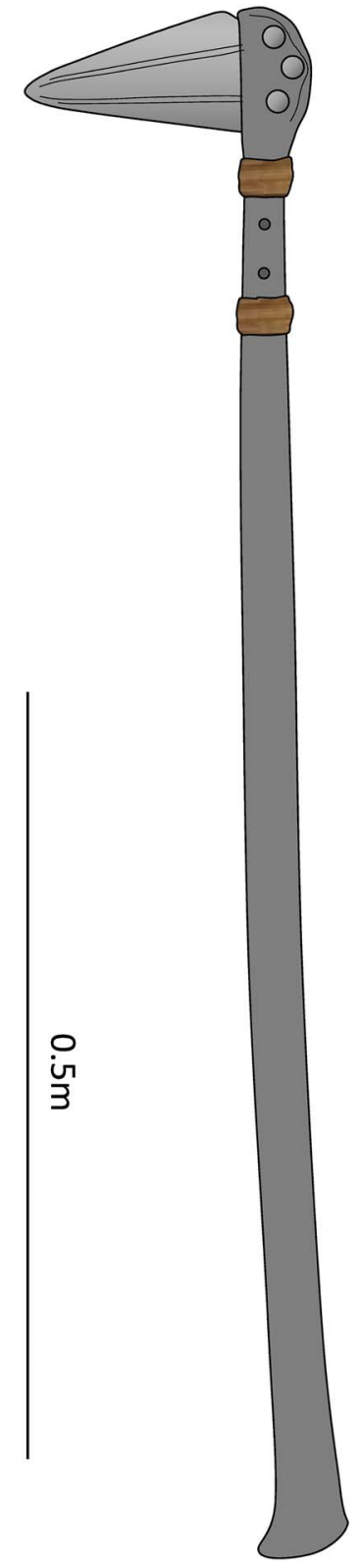

Fig. 18 .

Conjectural reconstruction of the Trecastell halberd in its full haft; the length of the handle is based on evidence from Carn and Ri Cruin; drawing: Stuart Needham

daggers, but these begin in Britain and Ireland only in the latter stages of halberd use.

There are three possible ways of constructing a split grip (Fig. 20): 1) two separate grip-plates joined to a third piece of wood constituting the handle; 2) one grip-plate being an extension of the handle, the other a separate cut-away which was clamped back to it by the rivets; 3 ) both grip-plates being continuations of a handle which was split at the top end. The first option would require some complicated arrangement to ensure a strong union at a point where the handle would need to absorb considerable stress during strikes (Fig. 20a). The second and third suggestions are preferred, but the third presupposes that the split end could be opened up enough to facilitate the carving of their inner faces; use of green wood would be an advantage.

Some support for the regular use of either partial splitting or the cut-away technique may be drawn from the north European metal-hafted halberds. Bands of cast-in ribbing almost invariably ornament the hafts, sometimes distributed down the whole handle, but frequently concentrated in the stretch immediately below the blade (Fig. 21; Wüstemann 1995; Gedl 1980). Intermittent ribbing is also seen in some of the rock carvings (eg, Fig. 19g; O'Flaherty 2007) and could have served to provide a better grip whilst wielding the weapon. However, where they are concentrated in the upper part, it suggests instead skeumorphs of organic bindings which prevented the split running further down the handle on the wooden-handled prototypes. Many of the metal imitations also show a band of 'binding' above the blade; in nearly every case this is associated with the presence of an expanded 'pommel' and it is possible that they represent the binding of a separate pommel-piece to the top of the haft. A few of the metal-hafted halberds do not have a pommel and the top of the haft-grip simply continues the curve of the butt around the top rivet (Wüstemann 1995, nos 97-100).

A final point concerns the neat chamfering of the back of the haft-grip (Figs $4 \& 14$ ). This has been shaped in a sinuous, lobate line emphasising the rivet formation and to some extent echoing the likely sinuosity of the concealed metal butt. This detail illustrates that the shaping of the haft can contribute to the style of the complete weapon and at the same time it might reveal the line of the concealed hafting-plate.

\section{THE CLASSIFICATION OF HALBERDS \& THE IMPORTANCE OF BLADE PROPORTIONS}

As it became clear that the particular combination of features on the Trecastell halberd could not readily be matched in the Welsh corpus, a wider consideration was 

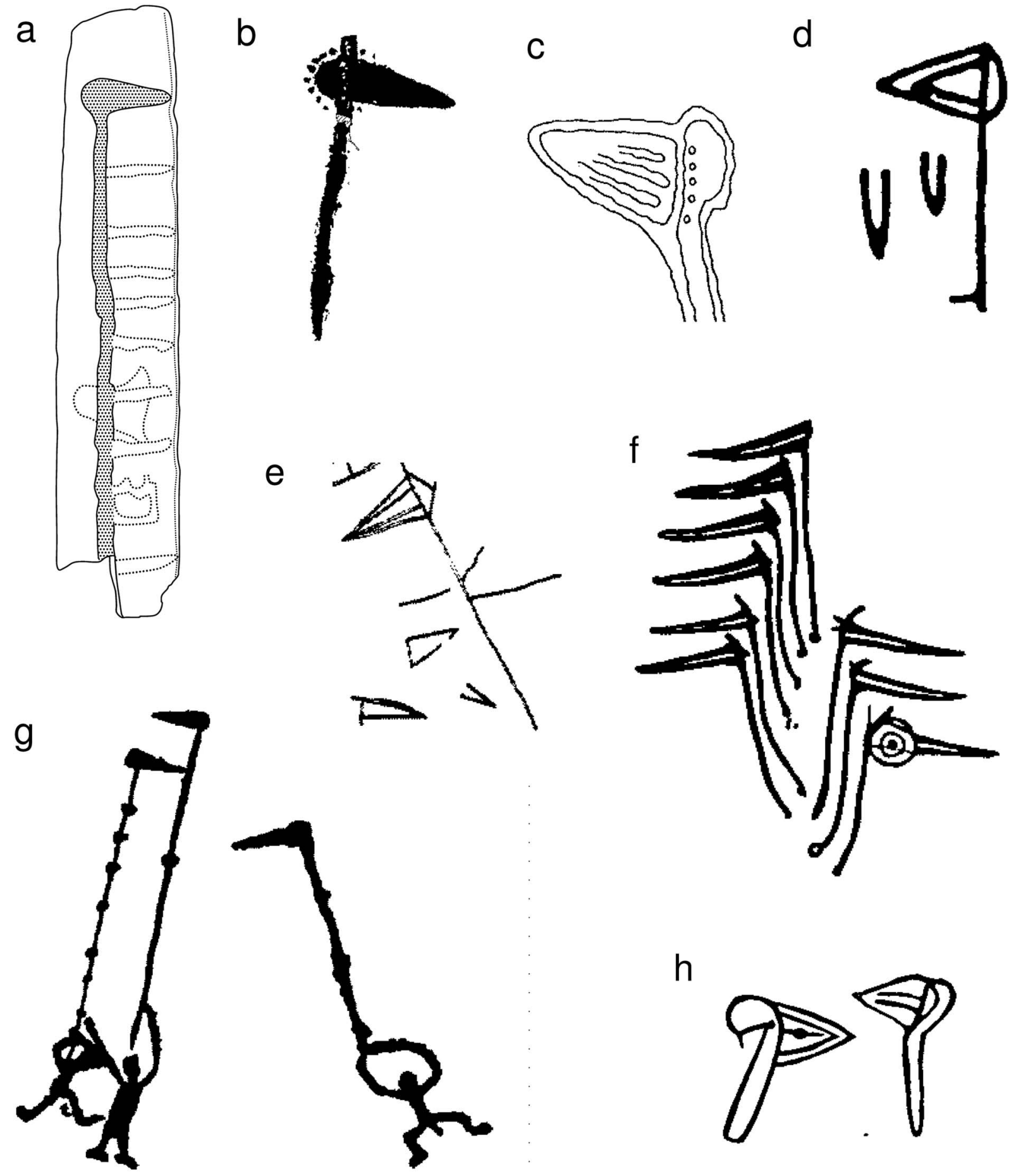

Fig. 19.

Carved depictions of hafted halberds with butt projections: a) Ri Cruin, Argyll \& Bute; b) \& c) Mont Bego, Alpes-Maritimes, France; d) Primadorna 1, Silleda, Spain; e) Termen, Ceto, Valcamonica, Italy; f) Montecchio, Valcamonica, Italy;

g) Fontanalba, Alpes-Maritimes, France; h) Atlas Mountains, Morocco; images: a) Needham \& Cowie 2012; b-e) Horn 2014; f-g) Abélanet 1986; h) Chernorkian 1988 


\section{S. Needham. EMERGENCE AND CONTEXTUALISATION OF HALbERDS IN WALES \& NW EUROPE}

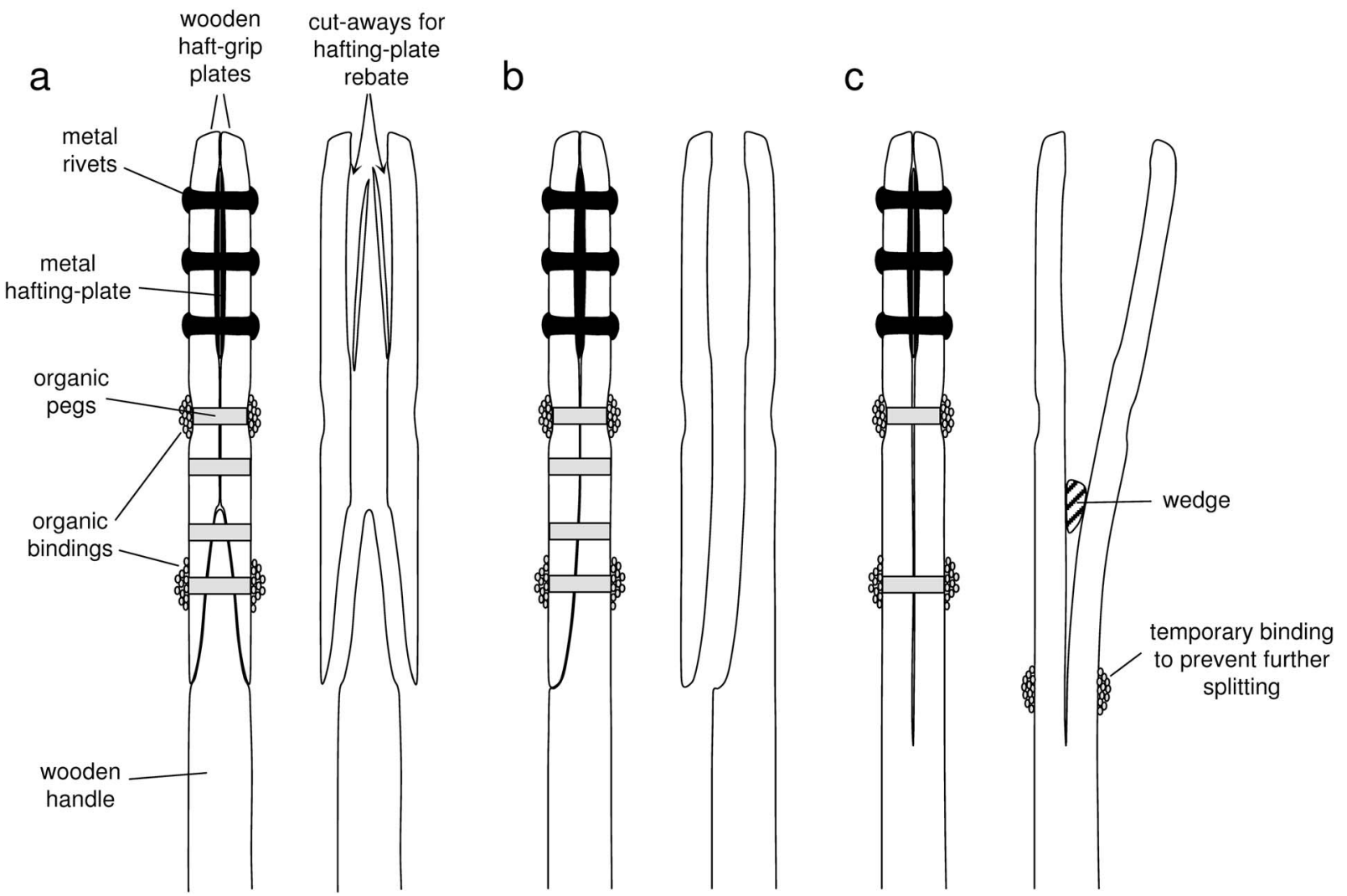

Fig. 20.

Options for split haft-grips on halberd hafts: a) two separate grip-plates; b) haft with one side cut-way; c) split upper haft; drawing: Stuart Needham

necessary. Continental material was reviewed from the literature while the majority of British and Irish halberds were studied at first hand. One feature of the Trecastell halberd that sets it apart from most other halberds is the relatively short blade; shoulder width is not however reduced and hence the overall proportions of the blade are squat. The importance of blade proportions for the classification of halberds has not been appreciated before, for example Ó Ríordáin made use of size in his scheme (1937), but appears not to have recognised the value of proportions (see further discussion in Appendix S1). Yet this is one of the most visible attributes of the mounted halberd and arguably one of the most significant in terms of everyday perception of style (Figs $5 \& 18$ ). Blade proportions (excluding hafting-plate) are therefore used as one of the primary attributes for the new classifications detailed in Appendix S1. In the width/length plots (eg, Fig. 30), they are represented by the gradient of the line to the graphs' origins. The best definition of types was found to involve a combination of proportions and actual size (e.g. Fig 30), also in conjunction with other distinctive features.

Other key attributes used to varying degrees for classification are: blade and midrib curvature; shoulder shape; hafting-plate shape and depth; haftline angle; and rivet number, formation and thickness. Important supplementary details are: midrib width; midrib cross-section, and blade wing features (such as furrows). The resulting classification schemes are illustrated in Figures $22 \& 23$ and summary catalogues of all known insular halberds are provided in Appendices S2 \& S3. Different classification structures arose for the Irish and British corpora and these are summarised in Tables $2 \& 3$.

The size of the Trecastell halberd and its early date raise interesting new possibilities for deducing halberd evolution in the region. While theoretically small 


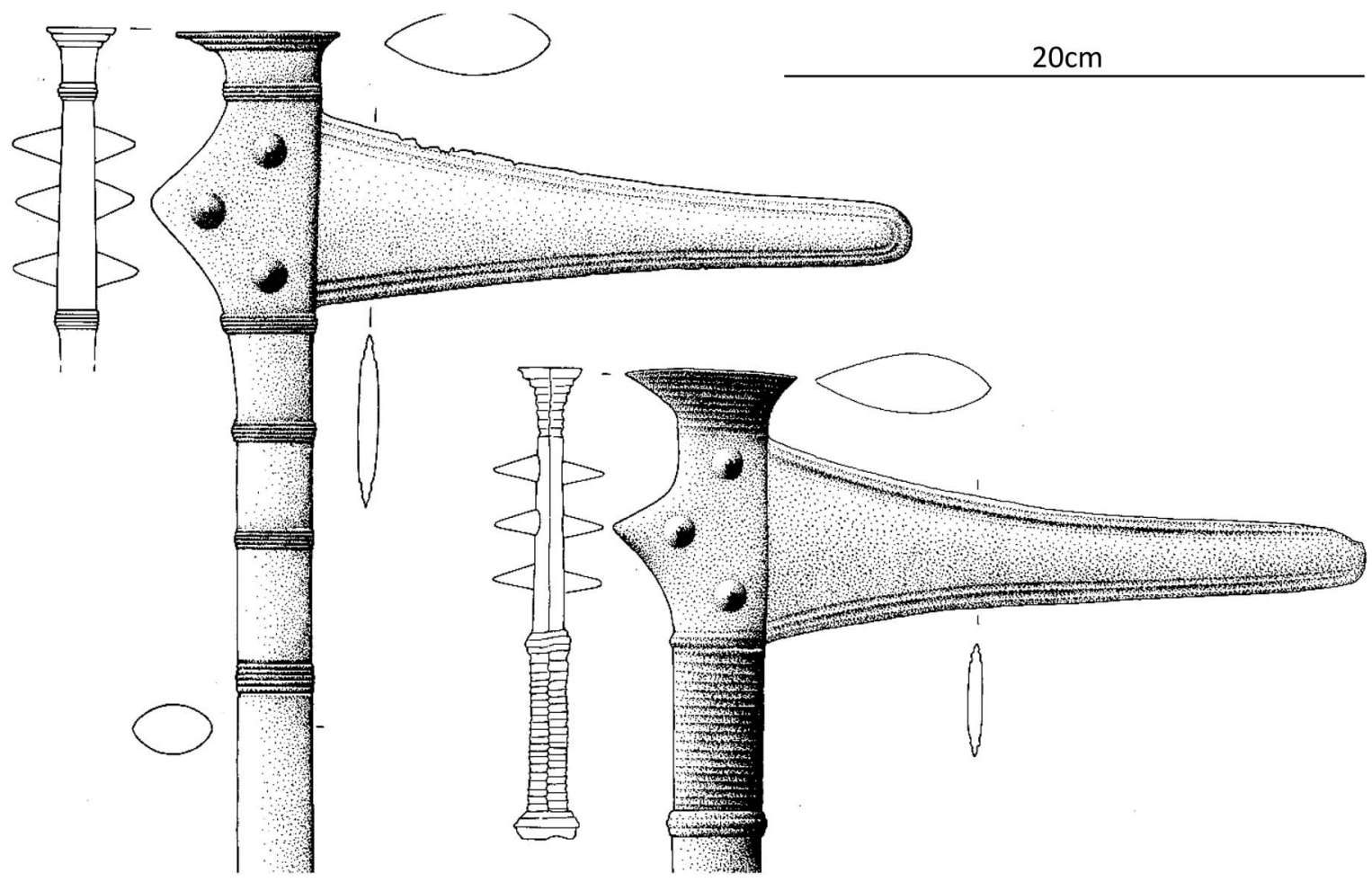

Fig. 21.

Examples of north European metal-hafted halberds with skeuomorphic binding around the hafts: left, Welbsleben; right, Melz (Wüstemann 1995, nos 124 \& 106); scale 33\%

halberds are not the same as squat halberds, in northwest Europe they comprise largely overlapping groups. Since squat halberds have been discussed in some detail elsewhere (Needham forthcoming), only a brief resumé will be given here. Squat or other small halberds are not very frequent finds on the nearContinent and are even rarer in Britain (Fig. 24). These halberds are actually rather variable in detailed form (Fig. 25), although most have just three rivets and several have rather broad midribs, a feature which is rare in more established, larger halberd types. It is only in Ireland that finds are a little more numerous and also rather more standardised, comprising two types defined as Type Roscrea with three rivets and Type Clonard with four (Appendix S1). There are also two unclassified squat halberds, including that in the Whitespots hoard, Co Down (Appendix S3, Cat. No. 167, Fig. S7a). Significantly, Irish squat halberds again include a number of examples with broad midribs and it can be seen from Figure 24 that there may be a geographical basis to the distinction between broad and narrow midribs, one that cuts across the type definitions.

The Trecastell halberd has been attributed to Type Roscrea and may therefore be an Irish import. This is consistent with its Irish type metal composition. However, it should be noted that the rivets form a wider triangle than is typical of the type (Appendix S1, Fig. S7a).

\section{PROBLEMS IN CONCEPTUALISING HALBERD DISSEMINATION \& REGIONAL UPTAKE}

The traditional problem for reconstructing halberd evolution both internally within regions and on a panEuropean scale has lain in the sparseness of independent dating or critical associated finds in many of the key regions. This situation is improving. For example, it is clear now from various strands of evidence that halberds were only in use in Britain and Ireland during the Chalcolithic (2450/2400-2200/2150 BC) and the earlier part of Period 2 (c. 2200/2150-2050 BC; Needham 2012). Faced with this relatively short currency of 
S. Needham. EMERGENCE AND CONTEXTUALISATION OF HALbERDS IN WALES \& NW EUROPE
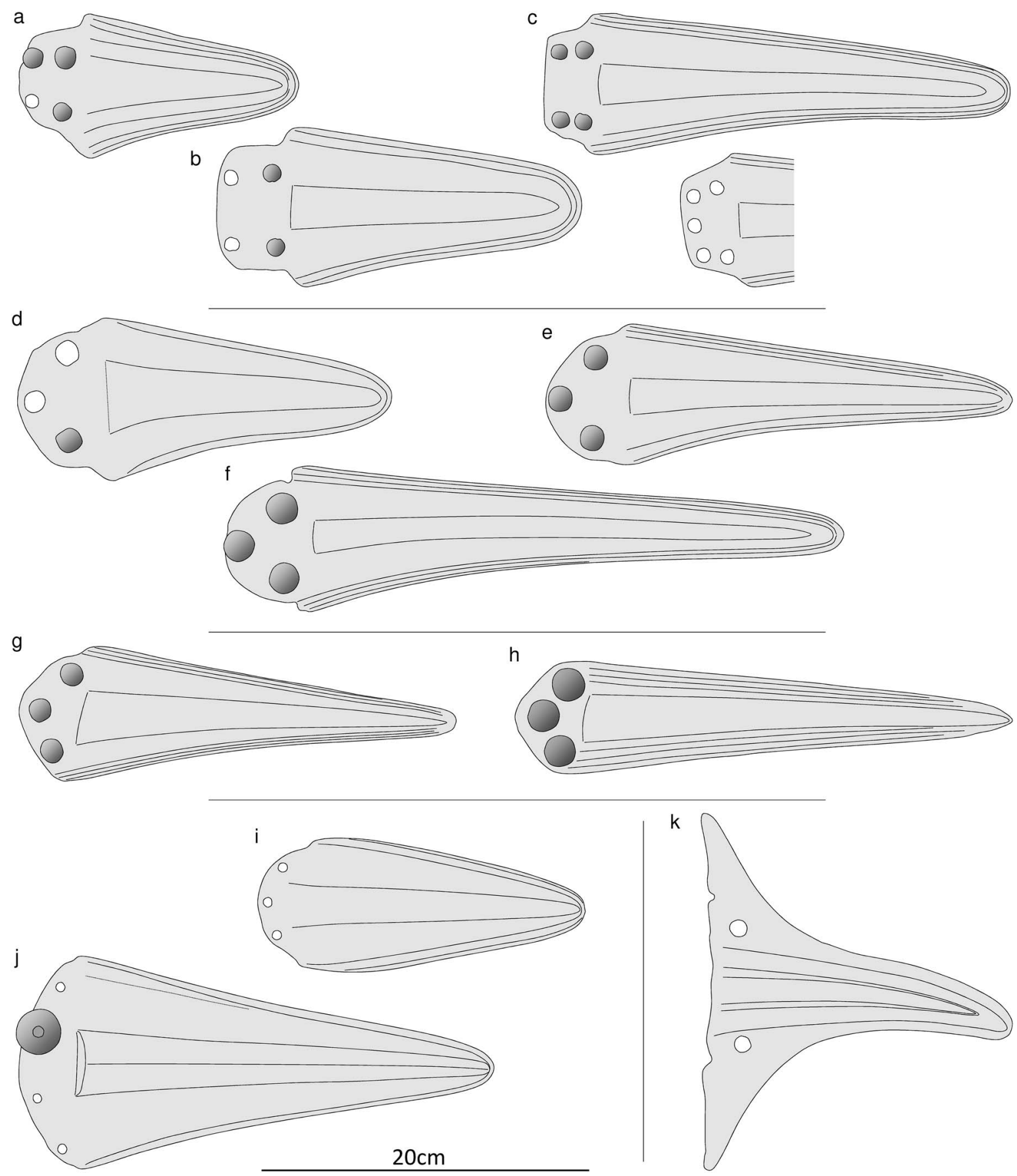

$\mathrm{k}$

Fig. 22.

Type series of Irish halberds: Clonard series - a) Type Clonard; b) Type Ballygawley; c) Type Derrinsallagh; Hillswood series - d) Type Roscrea; e) Type Lough Gur; f) Type Hill of Allen; Corlurgan series - g) Type Cloonymorris; h) Type Corlurgan; Breaghwy series - i) proto-Breaghwy (Type Kilcolagh); j) Type Breaghwy; No series - k) Type Corrib scale $25 \%$ (see Appendix S5 for objects on which type series is based); drawing: Stuart Needham 

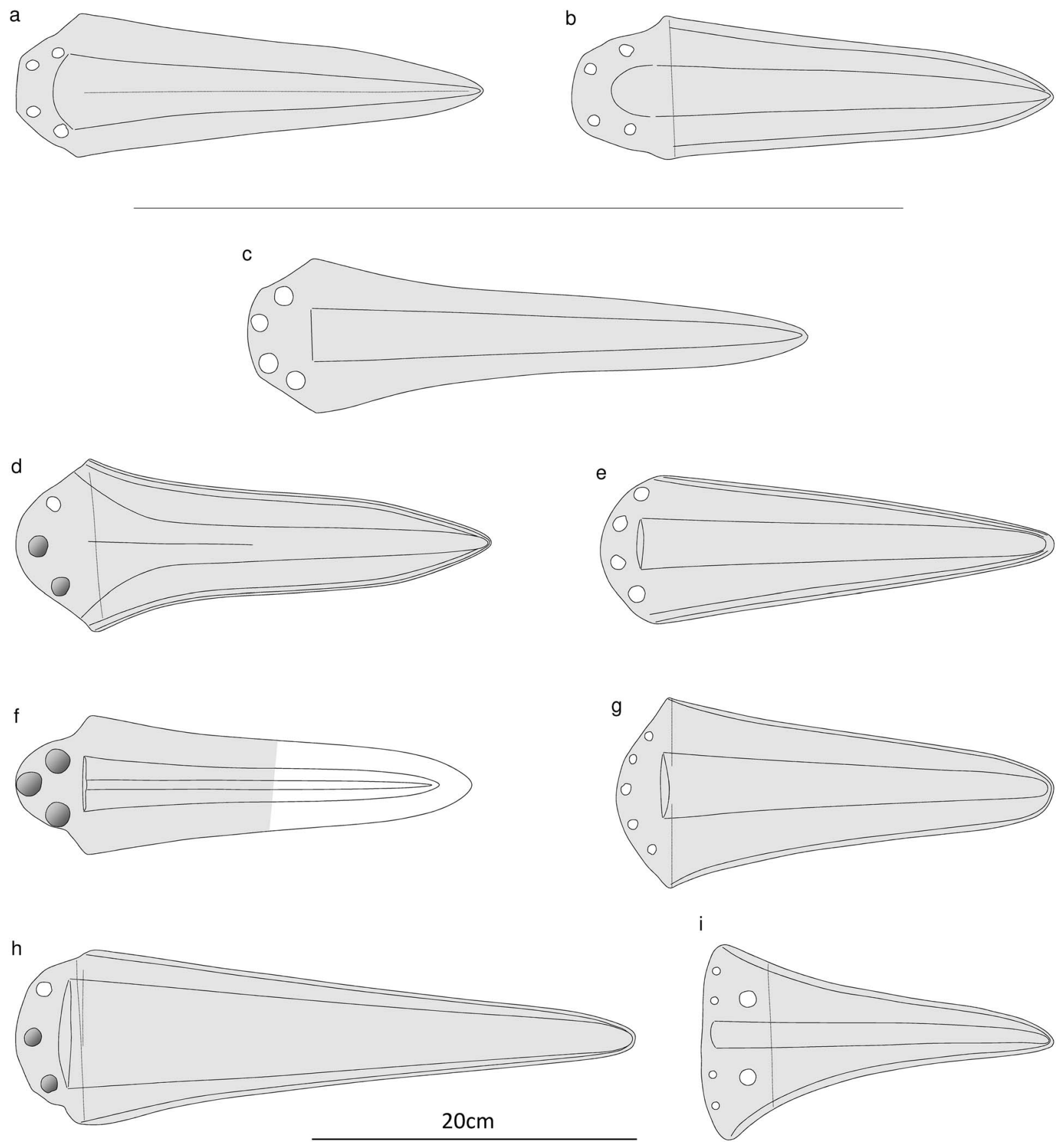

Fig. 23.

a-b) Examples of French Type Etigny halberds; c-i) Type-series of British halberds: c) Type Pistill Dewy; d) Type Pontrhydygroes; e) Type Sluie; f) Type Lambeth; g) Type Auchingoul; h) Type Crossraguel; i) Type Eweford; scale 25\% (see Appendix S5 for objects on which type series is based); drawing: Stuart Needham

perhaps only three or four centuries, any attempt to understand the evolution or succession of halberd styles requires rather refined chronological evidence.
There are several associations for Irish and British halberds (Appendix S4), not all secure and few offering any refined dating; either the halberds only occur 
S. Needham. EMERGENCE AND CONTEXTUALISATION OF HALBERDS IN WALES \& NW EUROPE

TABLE 2: SUMMARY OF THE CLASSIFICATION STRUCTURE FOR IRISH HALBERDS

\begin{tabular}{lll}
\hline Series (\& rivet no.) & Type or sub-division & Further sub-division \\
\hline Clonard (4; less frequently 5 or 6) & Type Clonard & $\begin{array}{l}\text { lenticular section } \\
\text { broad midrib } \\
\text { narrow midrib }\end{array}$ \\
& $\begin{array}{l}\text { Type Ballygawley } \\
\text { Type Derrinsallagh } \\
\text { Type Roscrea }\end{array}$ & $\begin{array}{l}\text { broad midrib } \\
\text { narrow midrib }\end{array}$ \\
Hillswood (3) & Type Lough Gur & \\
& Type Hill of Allen & \\
Ungrouped & Type Cloonymorris & \\
Corlurgan (3) & Type Corlurgan \\
proto-Breaghwy & Kilcolagh \\
Breaghwy (variable) & Type Breaghwy & Ungrouped \\
& Ungrouped & \\
No series (variable) & Type Corrib & \\
& Miscellaneous & \\
\hline
\end{tabular}

TABLE 3: SUMMARY OF THE CLASSIFICATION STRUCTURE FOR BRITISH HALBERDS (EXCLUDING THOSE OF IRISH STYLES)

\begin{tabular}{ll}
\hline Rivet no. & Type or sub-division \\
\hline three & Type Pontrhydygroes \\
& Type Lambeth \\
& Type Crossraguel \\
& Continental three-rivet \\
styles & Ungrouped \\
& Type Pistill Dewy \\
four & Type Sluie \\
five & Ungrouped \\
six (in two tiers: four plus two) & Type Eweford \\
variable & Type Auchingoul \\
\hline &
\end{tabular}

with other halberds or, where other types are present, they themselves are only datable to a broad period. The more closely dated hoards seem consistently to fall between the late Chalcolithic and the beginning of the Early Bronze Age, roughly between 2250 and 2050 BC. This may be a feature of changed deposition practices, early halberds having been deposited as single finds or only in association with their own class, and it should not be assumed that no halberds predated the late Chalcolithic. The associated finds do help show which types of halberd were in circulation at a late stage, even if an earlier start date for those types remains possible.

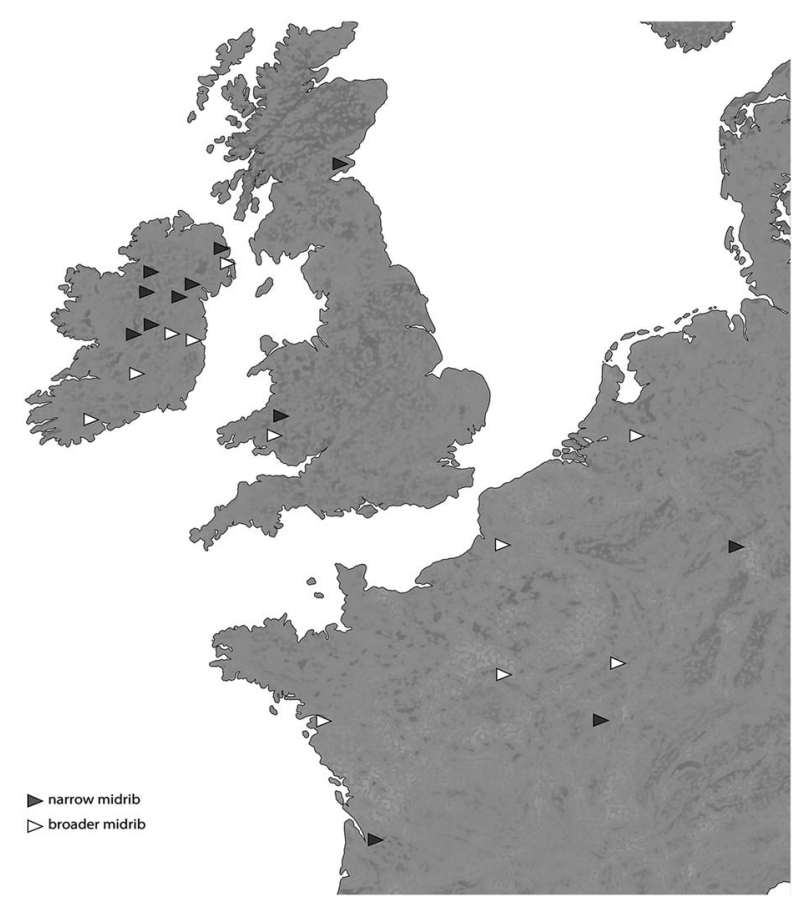

Fig. 24.

Map of recovery for squat and other small halberds in north-west Europe; drawing: Tony Daly, AC-NMW

Another valuable branch of evidence bearing on temporal development is alloy composition. Since the overall currency of halberds spans the transition from 

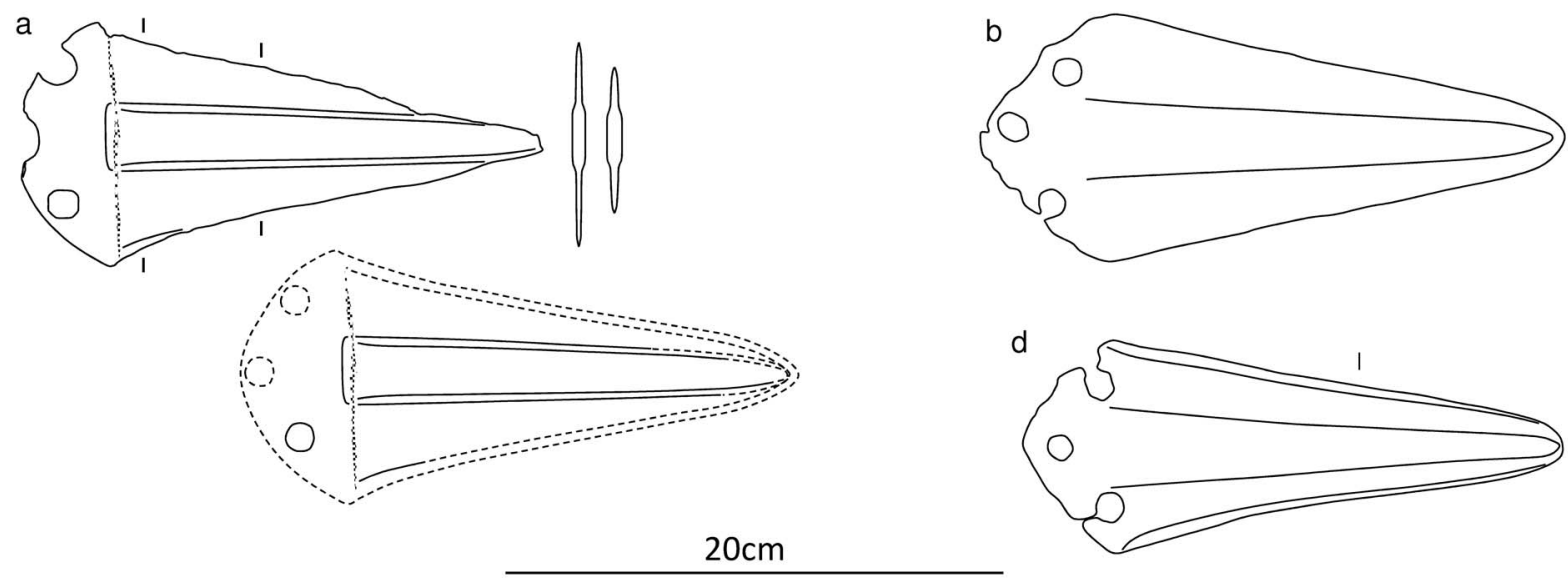

C
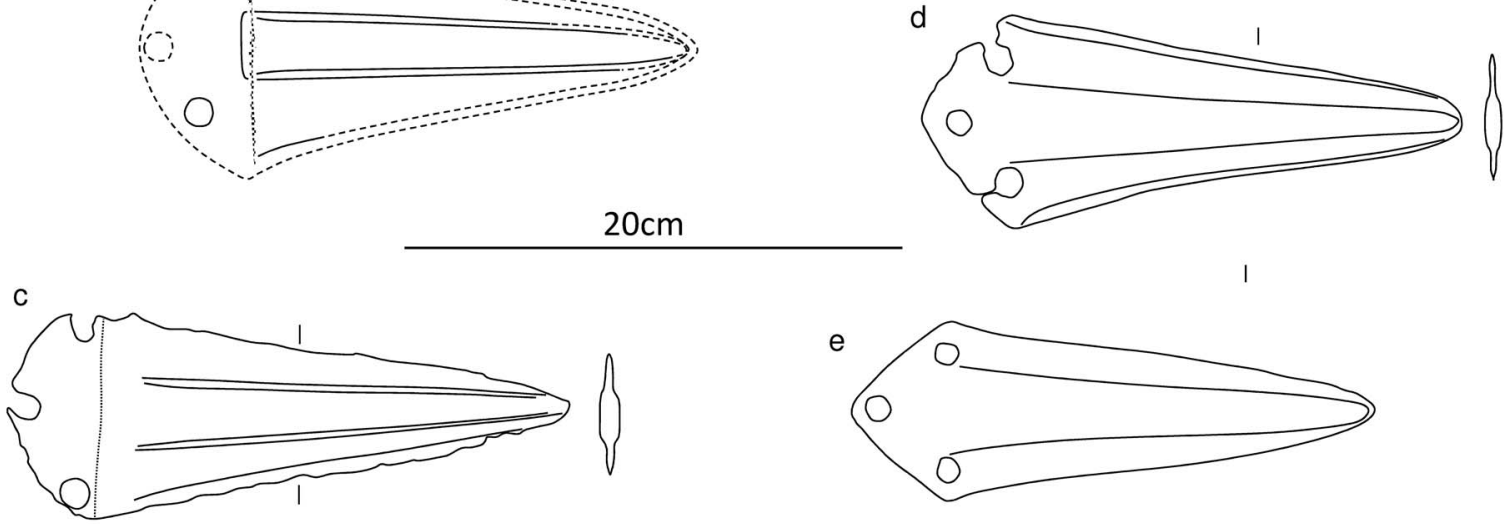

I
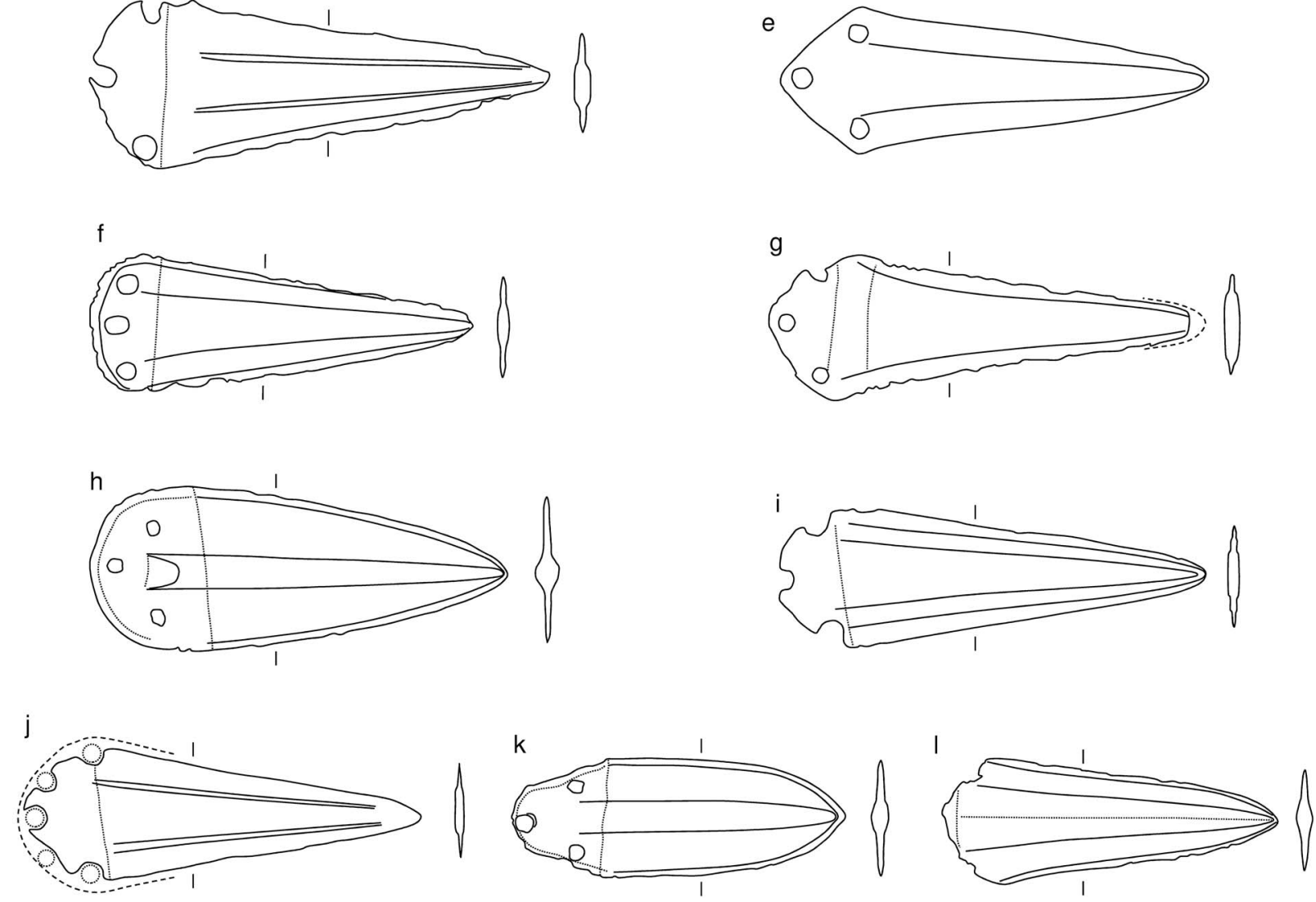

Fig. 25.

Squat halberds from Britain and the near-continent: a) Falkland, Fife (with reconstructed outline); b) Glaney Wood, Powys; c) Beaune area, eastern France; d) Mainz, Rheinland-Pfalz; e) Saint-Denis-en-Val, Loiret; f) River Loire, Rouans, Loire-Atlantique; g) Euffigneix, Haute-Marne; h) Paimboeuf, Loire-Atlantique; i) Wageningen, Gelderland; j) 'Somme Valley', northern France; k) Eysines, Gironde; l) River Loire, Nantes; scale 25\%; drawings: Stuart Needham, based on a) personal observation, b) O Ríordáin 1937, c, f-h, j-l) Gallay 1981, d) Gebers 1978, e) Despriée 1983, 


\section{S. Needham. EMERGENCE AND CONTEXTUALISATION OF HALBERDS IN WALES \& NW EUROPE}

copper to bronze metallurgy, probably fairly shortlived in these islands, their alloy state may help establish a sequence. Many insular halberds have been analysed (e.g. Coghlan et al. 1963; Junghans et al. 1968; Coles 1968-9, 97; Northover 1999) and it is therefore known which particular types were typically made of copper and which of bronze. The assumption that this represents a general sequence is supported by the few examples of associated finds. Two radiocarbon determinations now provide a third crucial branch of dating evidence. The Trecastell result cited above is entirely consistent with a Chalcolithic date and the probability distribution centres somewhere in the middle of the period. Meanwhile, the date recently obtained on small haft fragments (probably oak) attached to a halberd from Lough Ree, Ireland
(Cat. No. 131), is a little later: 2294-2134 cal вС (Bell 2014) and this is consistent with the blade having been made in bronze. Other analysed examples of its type (defined as Type Corlurgan - Appendix S1) are made in copper and it is therefore pertinent that this is one of the earliest determinations yet for a bronze artefact in these islands even allowing for some age-offset due to wood growth stage.

Metal-headed halberds had a long ancestry before appearing in Britain and Ireland (Fig. 26). Christian Horn (2014) has reviewed the pan-European evidence and argues that the earliest halberds occur in parts of the Carpathian Basin and parts of Italy. In these regions some examples occur in grave contexts dating to the mid- to late 4th millennium $\mathrm{BC}$, far too early to have had a direct bearing on the insular series that

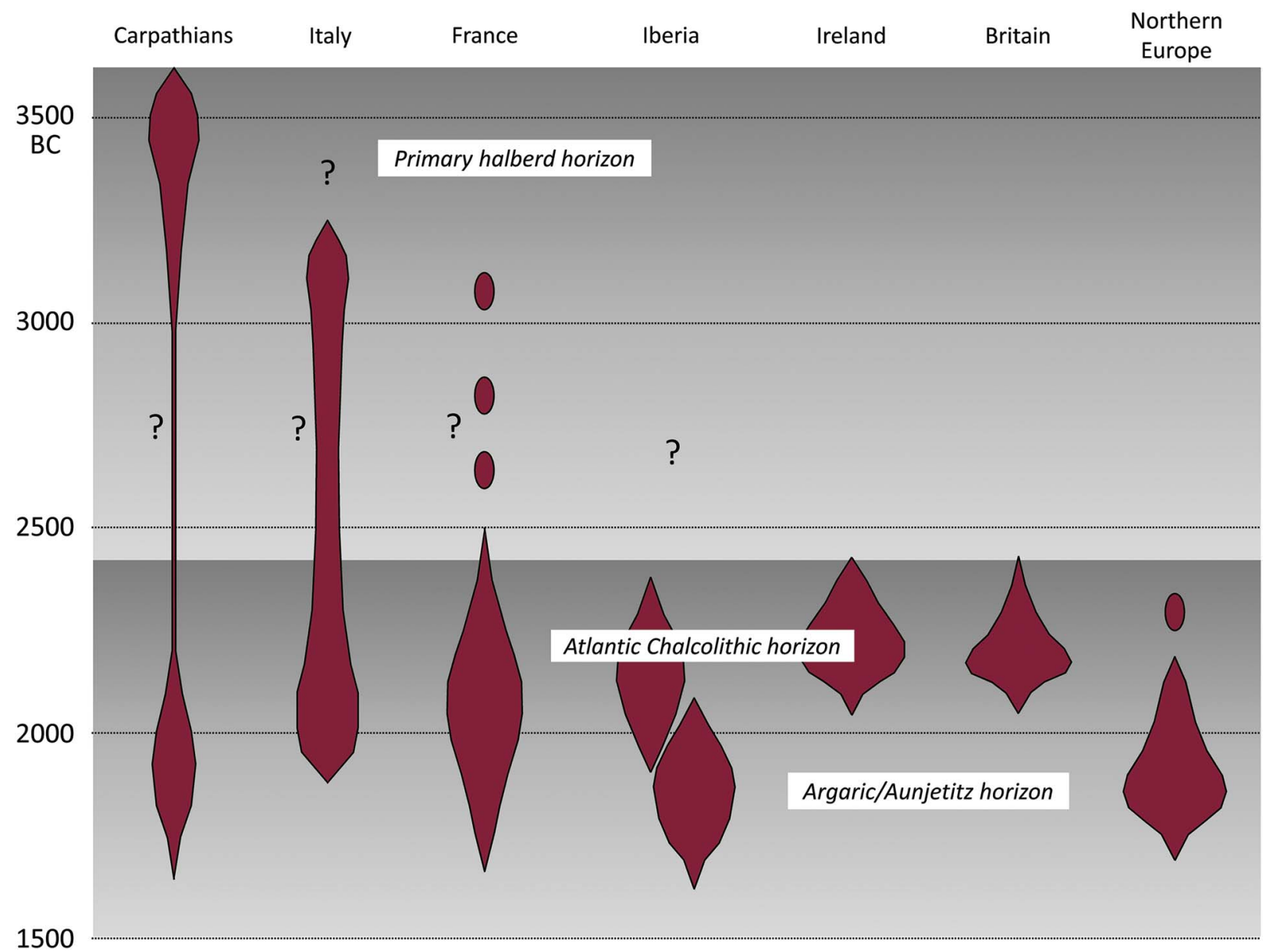

Fig. 26.

Summary chronology for halberds in Europe 
emerged centuries later. The north Italian clusters of halberds seem most likely to be the source of the halberd idea as it spread further west, including to southern Iberia (Horn 2014, fig. 104).

There may be question-marks hanging over the identification of some of the 4th millennium implements as halberds. A start date for the Italian series as early as the third quarter of the 4th millennium is based solely on the blade from Rinaldone grave 3 (Horn 2014, 84-5) - a symmetrical blade with symmetrically disposed rivets and surviving haft traces, the grain of which is co-aligned with the blade (Bianco Peroni 1994, no. 30). Both the straight hilt-line and broad blade can be matched amongst Bianco Peroni's Type Remedello daggers (1994, amongst nos 1-16; Fig. 27). [A more convincing halberd blade from Calvatone (ibid., no. 84) retains similarly aligned wood traces, perhaps indicating an 'elbow' or jointed hafting such as is occasionally represented amongst the Italian rock art (e.g. at Paspardo and Valtellina;
Horn 2014, fig. 46B-D)]. If Rinaldone 3 is dismissed, halberds would be first attested in late 4th millennium contexts such as those from Montalto di Castro, Poggio Aquilone, Poggio della Sorche, and Casanuova di San Biagio della Valle (Horn 2014, 85-7). Three of these weapons are very similar to one another and placed in Horn's Variant 14b. After this early horizon there is actually a long lull in datable halberds during the earlier 3rd millennium BC (Fig. 26). In part this could be due to changed contexts of deposition rather than a real lull; in Italy in particular there are types that could potentially fill the vacuum such as Type Calvatone (Bianco Peroni 1994, 15-6). What is noteworthy is that, whether placed in graves or not, all demonstrably and potentially early halberd types are represented by very few examples and yet presumably cover several centuries of use.

Sparse representation over time is an issue that will be returned to. Another difficulty for the interpretation of halberd dissemination is that while the widespread
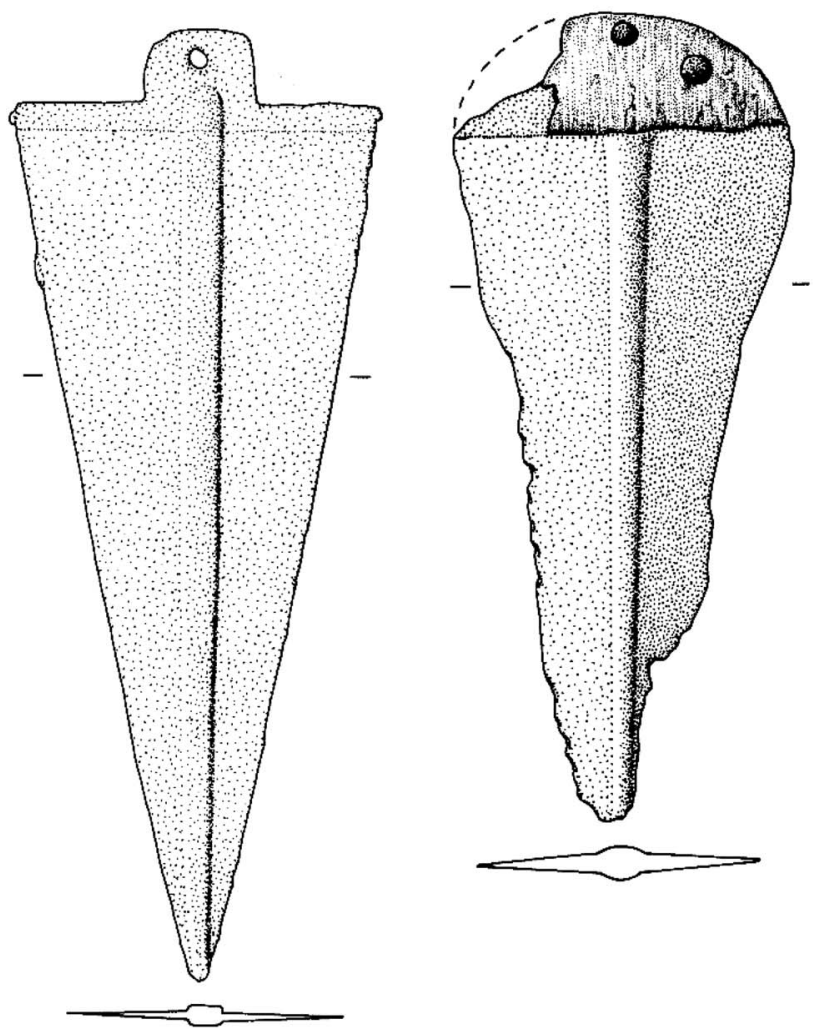

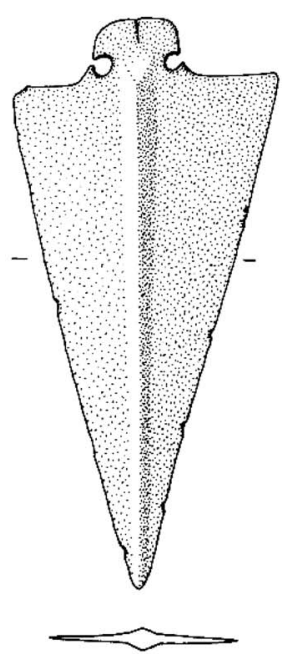

$10 \mathrm{~cm}$

Fig. 27.

The blade from Rinaldone grave 3 and comparable mid-ribbed dagger blades of similar proportions; left to right: Mirabella Eclano; Rinaldone grave 3; Remedello Sotto; Grotta del Castello diVecchiano; scale 40\%; images: Bianco Peroni 1994 


\section{S. Needham. EMERGENCE AND CONTEXTUALISATION OF HALbERDS IN WALES \& NW EUROPE}

recurrence of many specific halberd features suggests considerable inter-regional exchange of ideas, few actual objects were exchanged. Every halberd zone in western and northern Europe has its own particular halberd assemblage, sometimes dominated by one or two tightly defined types, sometimes more eclectic in their features. In fact, even the existence of clear imports in a given region does not guarantee a correct understanding of the initial transfer of the metal-halberd idea; reliance on individual feature comparisons alone is even more hazardous. For unravelling the sequence of halberd uptake on a pan-regional scale the shortage of refined chronological evidence already noted may be further exacerbated by conceptual issues.

We are clearly only seeing fragments of complex long-term interactions resulting in myriad feature combinations. Not all of the 'similarities' that resulted need be significant in terms of direct contact - these things were just in the 'ether' of a wide-scale halberd flux. A second crucial point is that representation may be particularly poor early on, before certain regions took up the halberd idea with vigour and before improved metal supplies allowed increased production and the greater likelihood of archaeological fall-out in quantities that can give rise to recognisable patterning in the data. It may be helpful to model our approach with these two problems in mind.

Figure 28 shows some hypothetical halberd currencies in a series of zones in relation to one another. The upper diagram represents what is probably the normally (if implicitly) accepted model. An initial form is 'planted' in each respective region at different times. In each case it is assumed that the source of that transplant should be identifiable through typological connections, ideally the presence of actual imports from a source area. Given the strong regionalisation in gross assemblages outlined above, it would be necessary to posit (quite plausibly) that the planted form was rapidly transmuted to reflect local tastes and preoccupations. Further transmissions of ideas and style features are likely to continue to flow in various directions and these would have the potential to influence otherwise internally driven evolutionary trajectories. Without a highresolution chronology it can be difficult to distinguish between initial and subsequent injections.

The lower diagram uses exactly the same set of regional trajectories and identical on-going interactions in order to illustrate a slightly different mechanism for regional inception. Here it is recognised that we may not find specific initialising imports in any given region.
Since it now seems likely that the halberd idea was abroad for a long period of time before its vigorous and episodic uptake in some regions, it would not necessarily be represented initially by any rigidly defined types but instead by a basic concept of how a halberd should be distinguished from any other object class, especially daggers, battle-axes, and axes. In such a model, early halberds may be thinly spread, not necessarily all of the same material (Ó Ríordáin 1937; Brandherm 2004) and, furthermore, difficult to recognise collectively as a 'type'. The more archaeologically visible regional phenomena, namely the consistent presence of metalheaded halberds in recognisable styles, represent the stage at which particular societies and their metalworkers incorporated halberds in the core of their ideological fabric. In this model, inception in a region is not so much the result of transplantation, more that of a 'spark' within the undercurrent of the halberd idea; that spark represents the point at which the potential of the weapon type to serve necessary social goals was realised. Those social goals may largely have related to establishing cultural identities. This would not be a decision to be made lightly since in many of the regions concerned the particular metalworking and hafting skills would need to be attracted in from outside.

While it is possible that, in some parts of Europe, halberds of lithic materials played a part in the infusion of the halberd idea within a given cultural group, translation into metal forms only coming later (Ó Ríordáin 1937; Brandherm 2004), it is unlikely to have been a wholly internal development. Every society that used antlers as 'picks' had a potential halberd prototype, as was recognised by Coffey (1908-9, 109), but the production and mounting of metal-headed halberds could not be achieved with commonly held skills. Most metalworkers of the copper-working period in Atlantic Europe only produced flat-cast forms in univalve moulds, whereas halberds required skilful bivalve casting, probably in clay/sand moulds. At some stage neat furrowed mouldings were formed, probably cast into the blade surface and subsequently finished by grinding and polishing. Hafting would also have been quite an art, involving getting a close fit between thin hafting-plates and the wooden haft, creating co-aligned rivet holes through the sandwich, being able to judge sizes for the rivet blanks, and then having the know-how to clench them. A clenched rivet needed to be tight, but not so tight as to split the wood, to be compressed without over-stressing the metal, and to end up leaving 

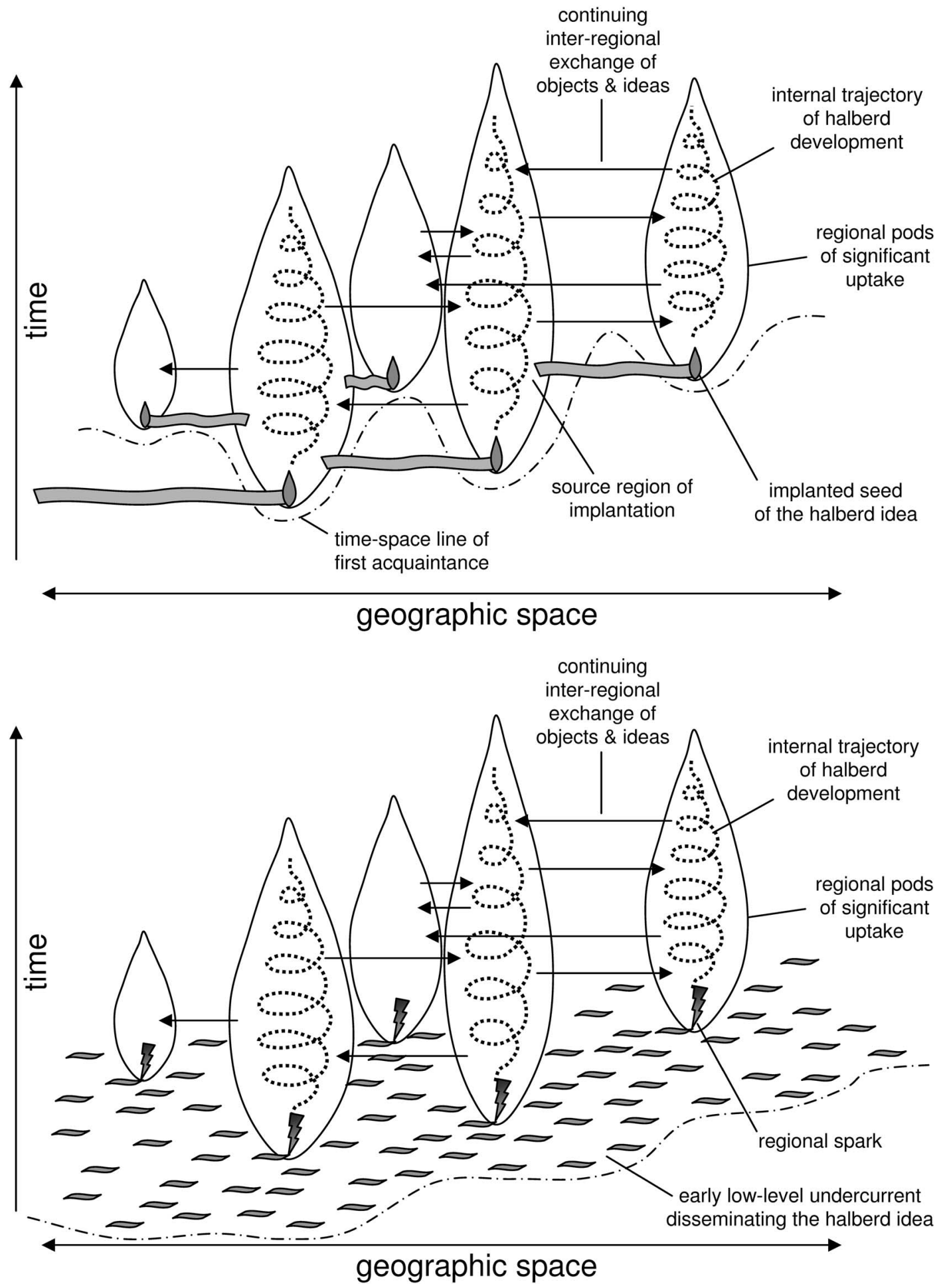

Fig. 28 .

Models for the uptake of the halberd idea 


\section{S. Needham. EMERGENCE AND CONTEXTUALISATION OF HALbERDS IN WALES \& NW EUROPE}

respectable heads for visual effect. Once this combination of skills had come together, they could be transmitted as a knowledge package from one halberd producing group to another; independent invention a second time over seems much less likely.

\section{PART 3: HALBERDS IN NORTH-WEST EUROPE, WALES, \& THE MARCHES}

\section{THE DEVELOPMENT OF HALBERDS IN NORTH-WEST EUROPE}

Several past researchers have attempted to understand halberd evolution at a pan-European scale, their conclusions being extremely disparate. The more modest ambition here is to identify evolutionary processes in north-west Europe. It is suggested that the best candidates for an 'undercurrent' of early halberds lie amongst the somewhat eclectic group of rather small copper blades already mentioned (Figs $24 \& 25$ ). Out of that undercurrent, regional groups with different feature preferences sparked into being according to new social objectives.

An early uptake can be postulated most readily for Ireland, simply because of the high recovery of halberds there (reasons for which are suggested in Needham et al. forthcoming). Of the 182 recorded examples (Appendix S3), the overwhelming majority of halberds from Ireland can be identified as distinctive insular products, but two possible external 'prototypes' need to be dismissed first. Harbison included in his corpus a halberd in the British Museum which is obviously of Italian Type Gambara (Cat. No. 169; Horn's Type 2; Harbison 1969, no. 312). The earliest mention of this implement was in a posthumous volume by Kemble $(1863,163)$, where it is stated to be from Ireland. However, the object has evidently never been registered and no early label survives so it is possible that Kemble, or British Museum curator Augustus Franks (one of the editors), simply made an assumption because of the frequency of halberds from Ireland. A suspicion that this object was in fact a souvenir from Grand Tour days might be reinforced by the existence of a second Type Gambara halberd in the British Museum's collections, likewise unregistered and unprovenanced (Neil Wilkin, pers. comm.).

The second case of possible external introductions involves Horn's Type 1, comprising finds from Italy and two from Ireland (Horn 2014, Taf. 1a-f). Both the piece from Ballybogy, Co. Antrim (Ashmolean Museum), and an unprovenanced Irish example (whereabouts unknown) clearly had significant damage to their hafting-plates (Cat. Nos 88 \& 99; Harbison 1969b, nos $143 \& 279$ ), the latter probably with one or more second-phase rivets. It is unnecessary to regard these as anything other than damaged/ reworked insular types.

If relatively small blades were the norm amongst the early 'undercurrent' of halberd circulation, then this would allow the two relatively squat Irish types, Clonard and Roscrea, to represent first insular 'uptake'. Neither type is found in the associations of late Chalcolithic date; moreover, the radiocarbon date for Trecastell favours a date before rather than after $2250 \mathrm{cal}$ BC for Type Roscrea. The currently unique squat halberd in the Whitespots hoard is also relevant here, and while the associated copper flat axe and simple tanged dagger (Case 1966, 162-3 fig 13.8-10) cannot be tightly dated, there is nothing to suggest it has to be late in the period.

Three-rivet halberds, albeit the rivets being set in a classic Mediterranean format of a shallow arc, go back to the early Rinaldone culture in northern Italy (Horn 2014, 85-90). As already mentioned, these date to the late 4th millennium $\mathrm{BC}$ and tracing a link over the intervening centuries is not easy. However, a halberd from Fontaine-les-Puits, south-eastern France, is recognised by Horn to be a copy of the early (Variant $14 \mathrm{~b})$ halberds of northern Italy $(2014,112)$ and a second French find attributed to Variant 14b, from the River Loire at Rouans (Horn 2014, no. 10.31; Gallay 1981, no. 506), has thicker rivets but is otherwise comparable. Fontaine-les-Puits and Rouans (neither has been analysed) may represent the earliest trans-alpine acquaintance with metal-headed halberds.

Other three-rivet halberds from France could easily be developments from such initial stimuli. In particular, the halberd from the Beaune area (Gallay 1981, no. 509) with its deeper-arched hafting-plate is nevertheless similar in proportions and midrib to a few of the broader Mediterranean weapons, most notably those from Poggio delle Sorche and Pomarance, both Tuscany (Horn 2014, nos $7.24 \&$ 7.25); Beaune is similar to the halberd from Falkland, Fife, and that in turn is similar to some attributed to Type Roscrea. It is noteworthy too that the Trecastell weapon itself has an unusually shallow rivet triangle for Type Roscrea. If this set of typological threads is acceptable, then they may represent the gradual spread of a three-rivet halberd model which nevertheless was being subtly transformed across space and time (Fig. 29). 


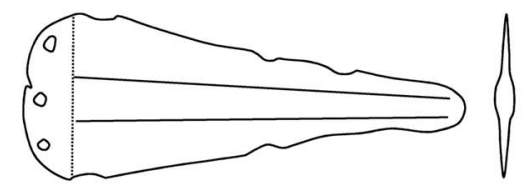

\section{pre-3000 BC}
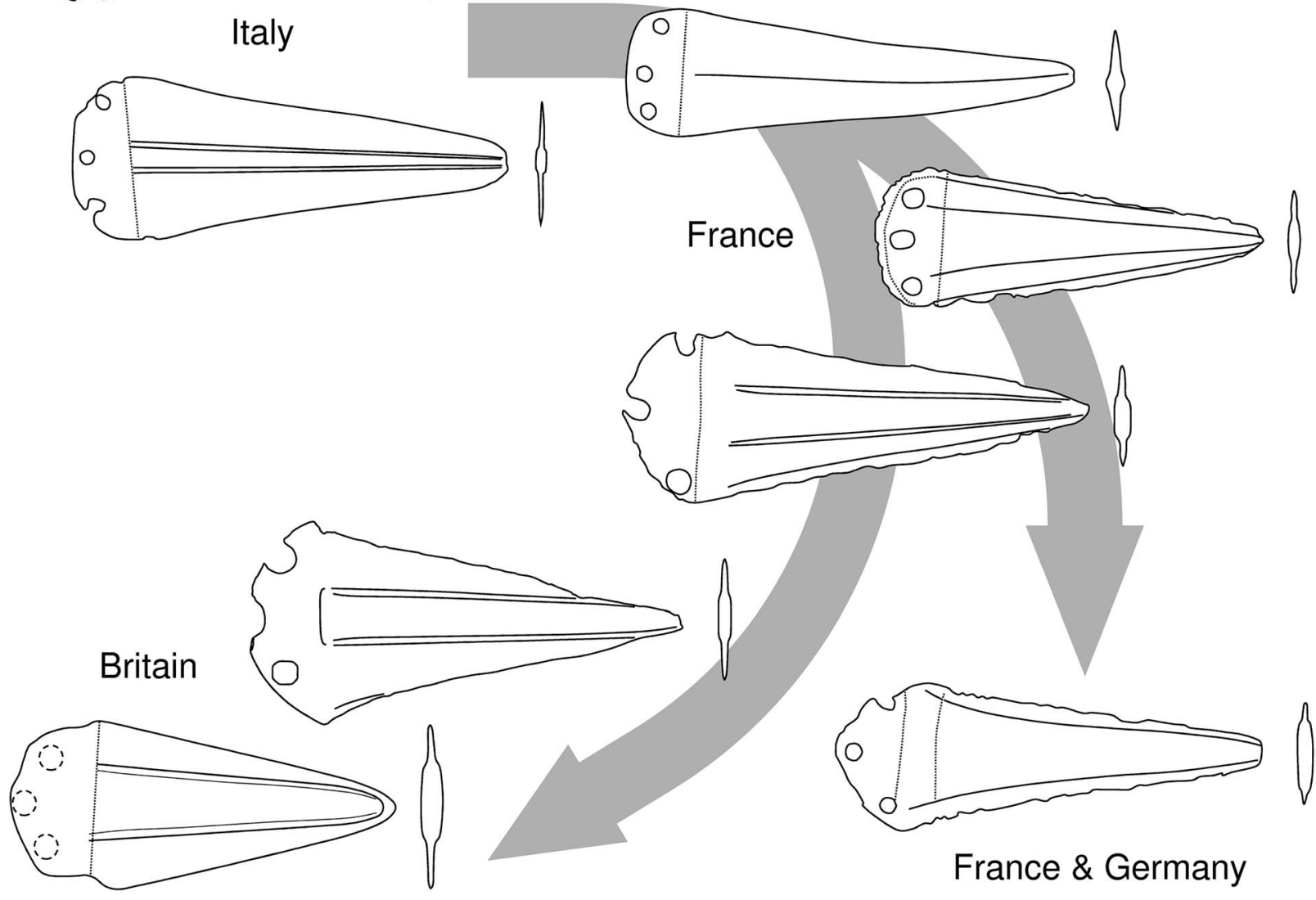

France \& Germany
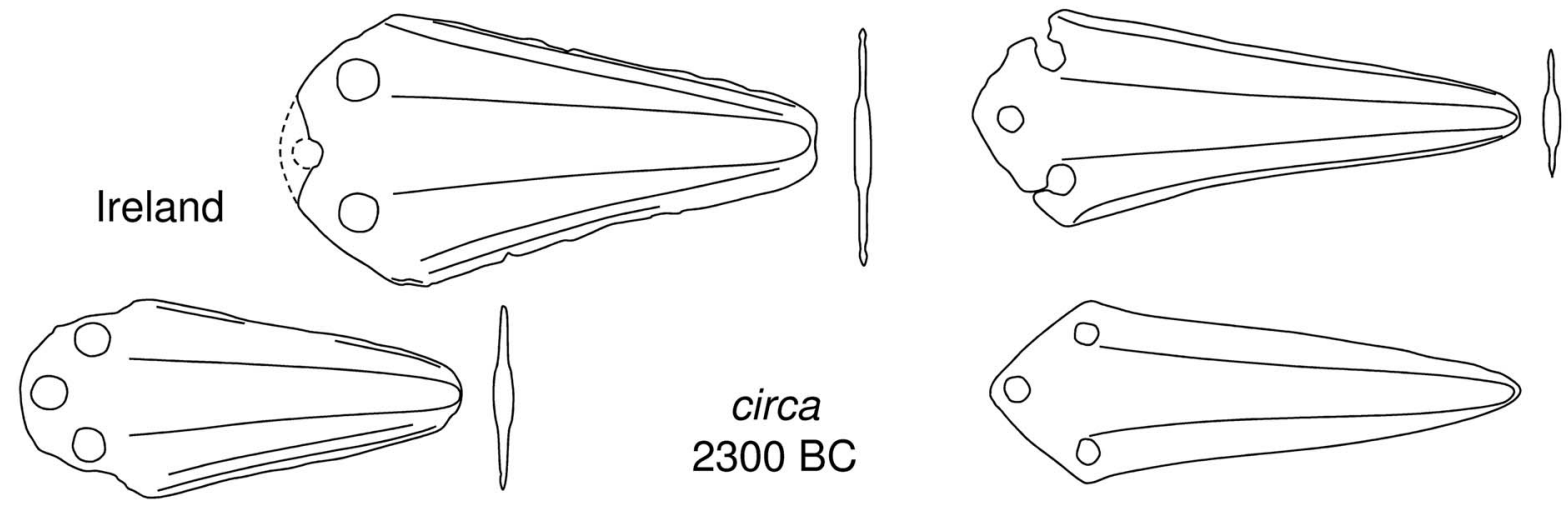

Fig. 29.

A possible thin typological thread connecting early halberds across western Europe. Note, this need not be the only thread

The four-rivet formation of Type Clonard could suggest a different background, unless it was an early insular modification. The French four-rivet halberds of
Type Etigny (Fig. 23a-b; Appendix S1 - see under Type Pistill Dewy) could be related, but at present there is no contextual evidence to establish whether 


\section{S. Needham. EMERGENCE AND CONTEXTUALISATION OF HALbERDS IN WALES \& NW EUROPE}

these started early enough to be antecedents. Outside France, a halberd resembling Type Etigny comes from Foiano della Chiana, Tuscany (Bianco Peroni 1994, no. 132), the region of early halberds in Rinaldone contexts. Another comes from a hoard probably from Vélez Blanco, Almería (Brandherm 2003, no. 1385); similar shouldered halberds in Iberia otherwise have only three rivets. Horn places one Type Etigny weapon, from Ris-Orangis (but no others), in his Type 16, which includes three distinctive five-rivet halberds from the Carpathian basin (Horn 2014, $58-9$, Tfn $49 \& 50)$. One of the latter is from the Velehrad-Rákoš hoard, Czech Republic, which is attributed to the Bodrogkeresztur culture, c. 3750$3400 \mathrm{BC}$, and it is difficult on present evidence to imagine temporal overlap between this earliest halberd type and Type Etigny. The next earliest contexts for halberds in the Carpathian Basin are of classical Aunjetitz date, after 2000 BC (Horn 2014, 74-5).

A crucial point in considering the subsequent evolution of Irish halberd types is therefore the likelihood that there were two or more typological strands from the very beginning, in contrast to the unilinear trajectory envisaged by Ó Ríordáin (1937). Both types of squat Irish halberd can be recognised to belong to much larger families, or series, of halberds with very comparable hafting formats but widely ranging blade lengths and proportions. In the case of Type Clonard, a Clonard series contains both medium-length - Type Ballygawley - and long - Type Derrinsallagh weapons (Fig. 22a-c). Meanwhile, Type Roscrea belongs to the Hillswood series, again with mediumlength - Type Lough Gur - and long - Type Hill of Allen - cousins (Fig. 22d-f; Appendix S1). While in principle these could represent variable size ranges to suit varied social status or wealth levels, there are reasons for suspecting they are not all contemporary. Moreover, the distributions on the plots of principal dimensions (Fig. 30) appear to show discontinuities; there is no sense that these are simply different sizes within a single uniform type. The medium-long and long types within the Hillswood series were probably in coeval use, since both are present in two hoards, those of Hillswood, Co. Galway, and Cotton Moss, Co. Down (Appendix S4; Hemans 1847-50; Ó Ríordáin 1937, 199). The Castell Coch hoard (Needham et al. 1985, A1) places a halberd of Type Lough Gur late in the Chalcolithic, suggesting that both this type and Type Hill of Allen belong to a late Chalcolithic horizon (see Fig. 31). Many examples of both types have been shown to be made of unalloyed copper, whereas none are yet known in bronze.

A third major copper-based group is that of the Corlurgan series which retains the basic format of three-rivets within an arched hafting-plate already seen in the Hillswood series. However, there are significant changes in both the styling of the haft end and a marked increase in the angling of the blade relative to the haft itself (Appendix S1). Although in this case there may be more of a dimensional continuum within the series, over half of the examples have unusually slender blade proportions that stand out against the wider halberd spectrum in Ireland and beyond (Fig. 22). These slender weapons have thus been defined as Type Corlurgan and the smaller, slightly squatter ones as Type Cloonymorris (Fig. 22g-h). The latter type overlaps the lower end of the Lough Gur distribution for principal dimensions (Fig. 30) and, given its new characteristics, it can be regarded as a departure from the classic Irish hafting-plate formation perhaps by metalworkers who split away from the mainstream Hillswood tradition. One example of Type Corlurgan is known to have been made of bronze (Lough Ree - see above), while in addition the probable Frankford association, Co. Offaly (Day 1892; Coffey 1901, pl. xxxiii), has a type of riveted knife that must be late Chalcolithic or transitional to bronze-working.

The fourth and final major Irish halberd series is termed the Breaghwy series here (Appendix S1; Fig. 22i-j). The main contained type, Type Breaghwy, is already well known (Harbison 1969, 46); as well as being consistently made of bronze, it represents something of a typological break from previous styles. However, there are four halberd forms made in copper that do not conform to any of the copper types described above and yet have some features in common with Type Breaghwy. These are interpreted as proto-Breaghwy halberds, forming part of the Breaghwy series. Another late style made in bronze is the extraordinary Type Corrib represented by only three examples and this, along with Type Breaghwy, can probably be regarded as the last flourish of the weapon type in Ireland. The proposed evolution of halberds in Ireland is summarised in Figure 31.

Of a current corpus of 64 halberds from Britain (Appendix S2), detailed morphological study has identified only a minority that have particular foreign affinities and do not belong to definable insular groups. As few as five halberds are of distinctively Irish types or have strong Irish affinities: Trecastell, Castell 


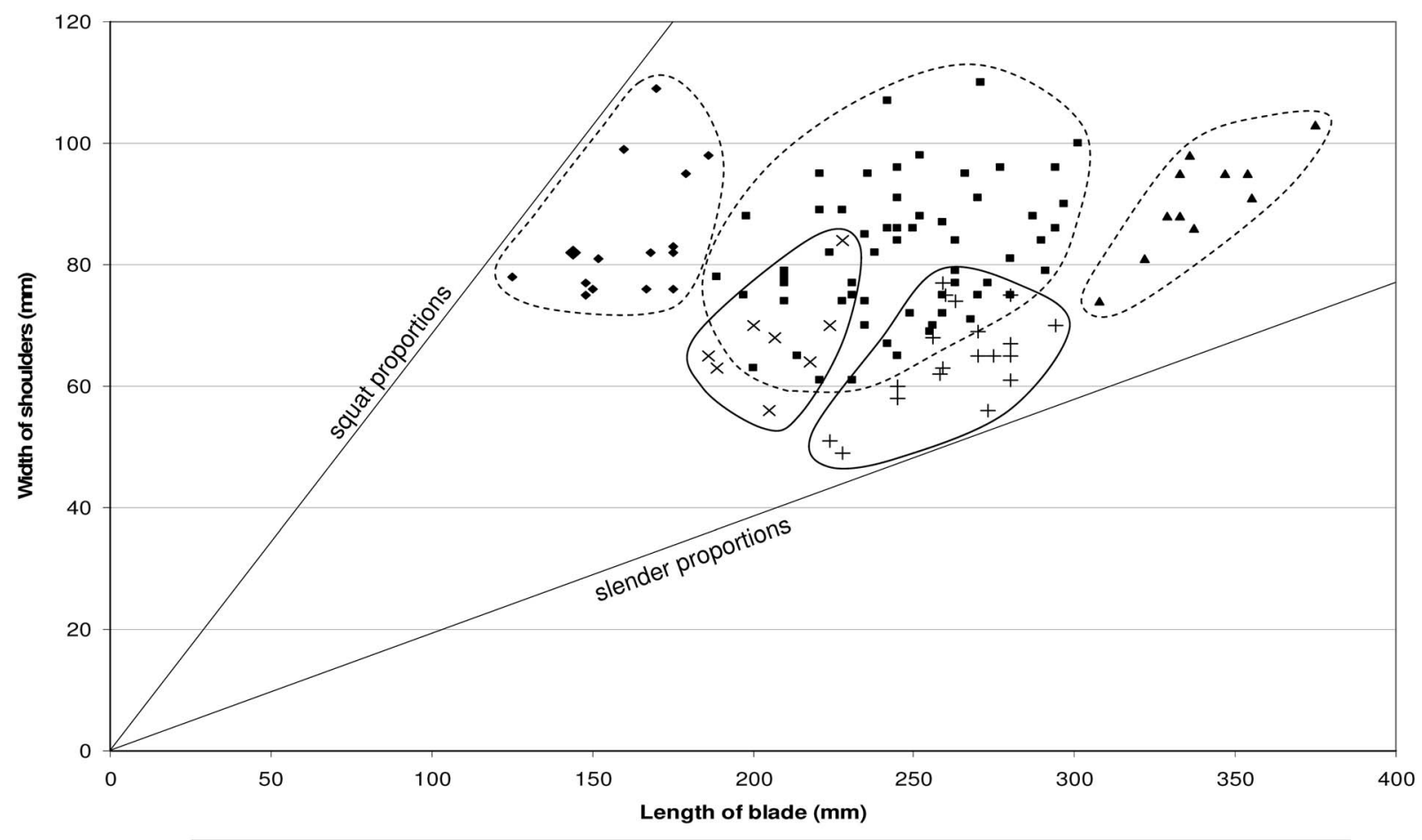

- Type Roscrea - Type Lough Gur ^ Type Hill of Allen $\bullet$ Trecastell halberd $\times$ Type Cloonymorris + Type Corlurgan

Fig. 30.

The distribution of principal dimensions of Irish halberds of the Hillswood and Corlurgan series (further plots are to be found in Appendix S1)

Coch 2 and Dolfrwynog in Wales, and Tom-na-Brataich and Whiteleys in western Scotland (Appendix S2, Cat. Nos 1-4, 9; most of these are probably imports from Ireland, although Dolfrwynog and Whiteleys deviate from their presumed Irish models, Types Lough Gur and Ballygawley respectively. Four more halberds of Irish type in Scottish Museums are actually all without provenance and may in fact be Irish finds (Cat. Nos 5-8). While the Trecastell halberd seems to show earlier Irish influence than the Lough Gur import in the Castell Coch hoard, even here we should be wary of assuming that this represents Britain's first acquaintance with the metal-headed halberd given the influential influx of people and concepts coming up from the south during the third quarter of the 3rd millennium BC. Certainly Type Roscrea seems to have had limited impact on British halberd styles.

Similarly, no more than seven halberds have fairly close parallels on the Continent; again some may be actual imports (Appendices S1 \& S2). Some are datable to a late horizon and would thus relate to the on-going exchange of ideas and objects amongst halberd makers and halberd users rather than to a phase of introduction. The Continental parallels for the weapons from Glaney Wood, and Maryport, Cumbria (before its butt was reworked), could be relatively early in their respective regions, but it is not yet clear whether they emerged early enough to be contemporary with the British Chalcolithic (Appendix S1).

Of the remaining 52 halberds, 43 have been placed in seven defined British types (Fig. 23c-i; Appendices S1 \& S2). The principal dimensions of British halberds (excluding those of Irish type) show a much more constrained distribution than those of Irish halberds (Fig. 32). Another aspect of differentiation is that a large minority (39\%) of British halberds were made of copper not matching the dominant copper type in use in Chalcolithic Britain, A-metal (Northover 1999; Needham 2002). Some, but not all, of the halberds of more Continental style are made of metal of presumed Continental origin, notably BB-metal and Arseniconly metal. The impurity classifications of analysed 
S. Needham. EMERGENCE AND CONTEXTUALISATION OF HALbERDS IN WALES \& NW EUROPE

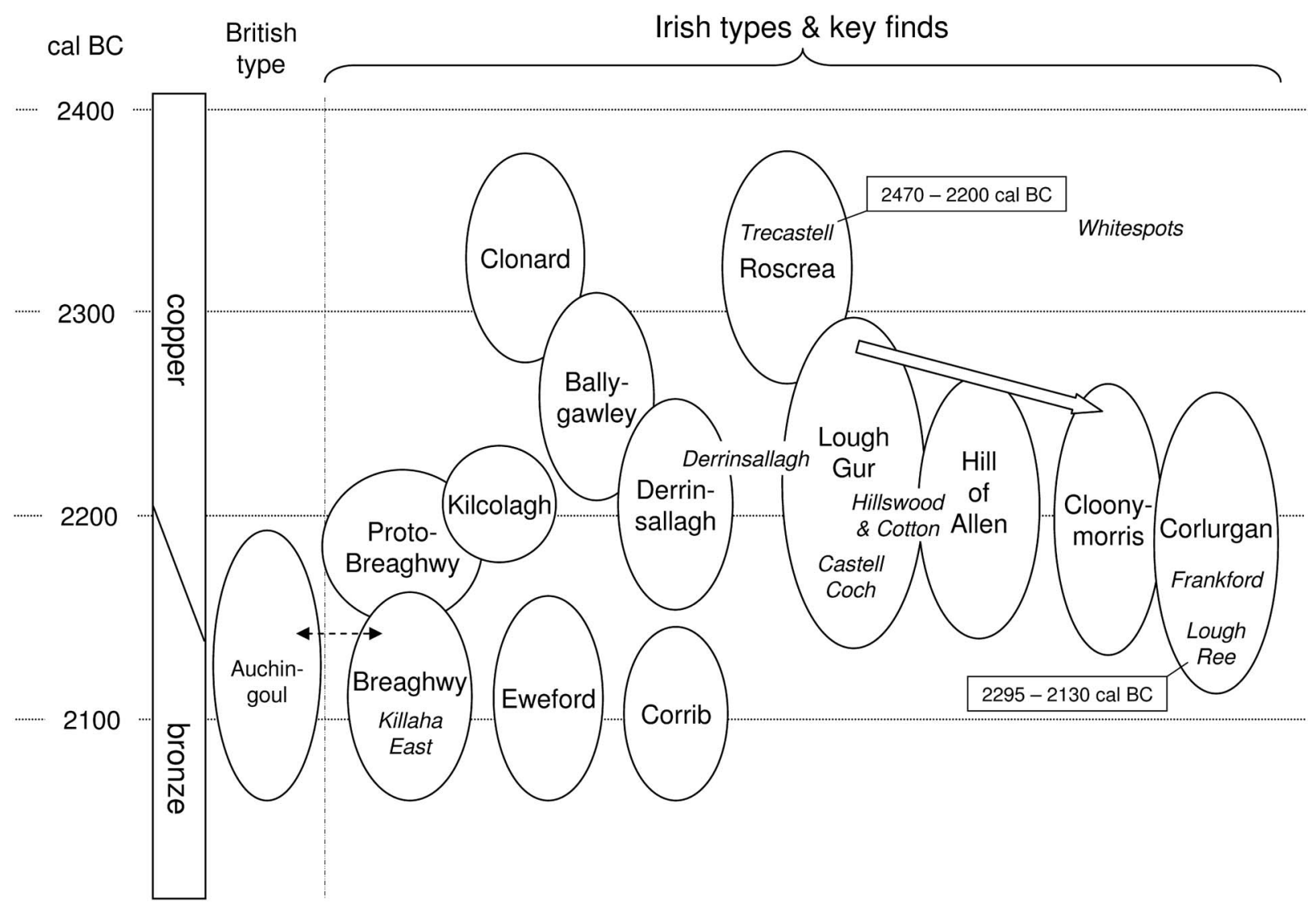

Fig. 31.

Suggested evolution of Irish halberd types; chronologies are not intended to be precise

halberds are given in Appendix S2, but are not discussed further here.

Since squat halberds in Britain are exceedingly few and moreover varied in form, halberd 'uptake' was probably associated with larger blades. The most frequent British halberd style, Type Sluie, is characterised by four rivets disposed in a moderate arc inside an arched butt-line (Fig. 23e), but this form has no obvious immediate external antecedent. A single Continental find, from La-Grande-Paroisse, Seineet-Marne (Gallay 1981, no. 525), possibly of this type is more likely to be an export from Britain than an antecedent. The minor British types defined are more complicated. All arguably have one or more features that relate them to an external type, but this can be exceedingly generic. The sinuous butt-line of Type Lambeth (Fig. 23f) recalls that on Iberian Type Carrapatas and Baútas halberds (Brandherm 2003, 372-7) as well as a new find from the banks of the River Loire at Avoine, Indre-et-Loire (Cordier 2009), but insofar as the dating evidence goes, it is likely they are not particularly early in terms of the insular series.

Probably the most compelling external connection is between British Type Pistill Dewy and French Type Etigny (Fig. 23a-c). While not identical in all respects, these two groups with their trapezoidal setting of rivets within a broadly trapezoidal hafting-plate are more similar to one another than either is to Irish Clonard series weapons. Neither group is numerous: four or five of Type Pistill Dewy; six of Type Etigny. Whether Type Pistill Dewy/Etigny played a significant role in the uptake of halberds in Britain is again thwarted by poor chronological evidence in both regions; however, if early enough, the type would provide a potential route for the derivation of the four-riveted Type Sluie.

More certainty can be given to the later phases of development because of the switch to bronze. While 


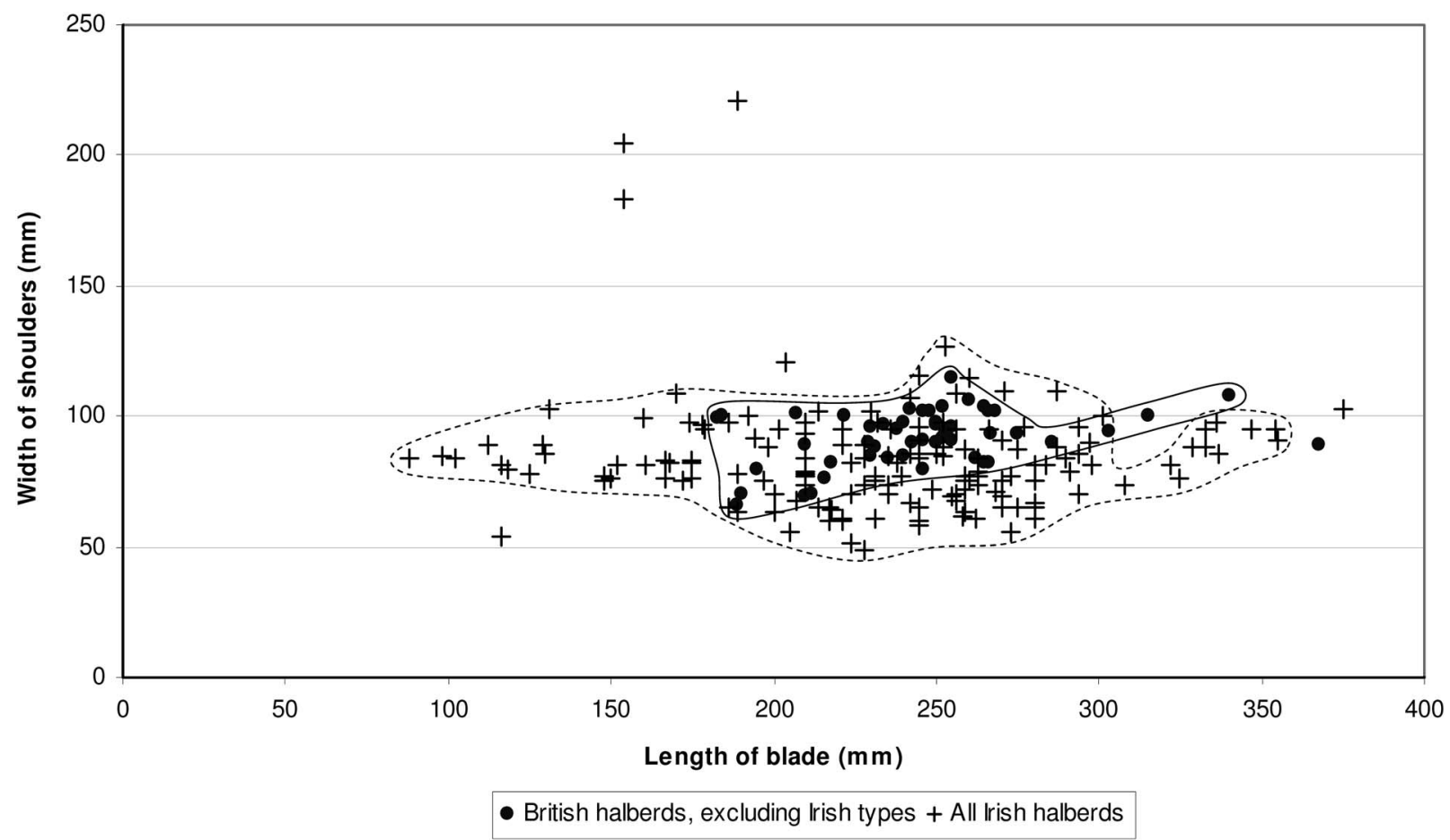

Fig. 32.

Comparison between principal dimensions of British and Irish halberds

nine of ten analysed Type Sluie halberds are of copper, those of Type Auchingoul, are mostly made of bronze; the exceptions are the one finished and three unfinished halberds in the Auchingoul hoard itself. This type has much in common with Type Sluie in terms of proportions, but rivets are now thinner and variable in number, and butt-lines tend to be shallower. A second bronze type - Type Eweford (Fig. 23i) - is represented by only two halberds (Cat. Nos 58-9), with a third from 'Ireland' (Cat. No. 163). This type too has a shallow butt-line and correspondingly shallow line of slender rivets, linking it both to Type Auchingoul and Irish Type Breaghwy and forming a cross-Irish Sea connectivity at the transition to bronze metallurgy. How this correspondence materialised is complicated by the fact that plausible prototypes can be found in both islands - Type Sluie halberds in Britain and protoBreaghwy halberds in Ireland. The correspondence is though too strong to be entirely coincidental and suggests evolutionary convergence as the respective insular types - Breaghwy and Auchingoul - crystallised. This implies significant contact and perhaps mutual respect between the halberd producing groups in Ireland and northern Britain at a time of strong interactions across the North Channel (eg, Needham 2004).

Bearing in mind all the uncertainties, a tentative model for the evolution of British halberds is presented in Figure 33. Early introductions and local derivations thereof are few in number and make a rather eclectic group. When more standardised types emerged, perhaps not until the middle of the Chalcolithic (c. $2300 \mathrm{BC}$ ), they were of reasonable length and often had four rivets - Types Pistill Dewy and Sluie although some minor types had three - Types Pontrhydygroes, Crossraguel, and Lambeth (Figs 23d, f, $\& \mathrm{~h})$. Amongst the more individualistic halberds not discussed here, three examples have five rivets.

\section{HALBERDS AND CONTEMPORARY METALWORK IN WALES \& THE MARCHES}

(Stuart Needham, Adam Gwilt, Mark Lodwick, \& Peter Reavill)

The Trecastell halberd adds to one of the foremost regions for halberd deposition in Britain; there are 
S. Needham. EMERGENCE AND CONTEXTUALISATION OF HALbERDS IN WALES \& NW EUROPE

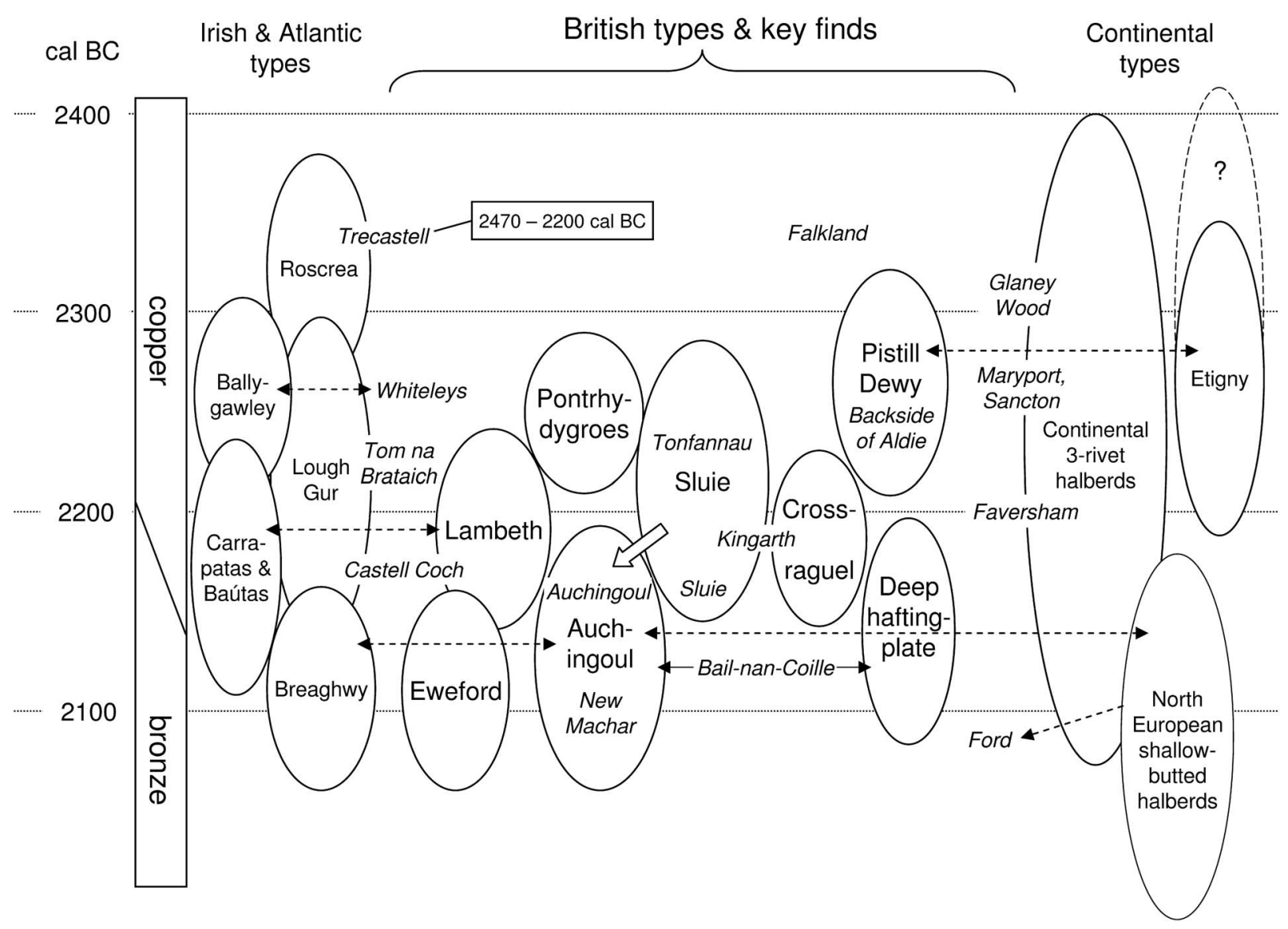

Fig. 33.

Suggested evolution of British halberd types; chronologies are not intended to be precise

now 13 weapons from 11 findspots in Wales and the Marches (Fig. 34). In addition, there is a stone univalve mould from New Mills, Powys, which bears three matrices (Green 1985); although not previously recognised as such, two of the matrices can only really have been for casting blanks for halberds (Fig. 35; Needham forthcoming); the third is probably unfinished. This univalve mould for making halberds is unique and poses some interpretational problems (ibid.); moreover, it is best dated to the beginning of the Early Bronze Age (Brithdir stage) whereas the halberds of the region should all be of Chalcolithic date. The New Mills mould and any products from it fit into the pattern seen elsewhere in Britain and Ireland, with a quick contraction in the use and deposition of halberds after the transition to bronzeworking.
Despite being relatively clustered, this Welsh halberd assemblage is rather eclectic (Table 4) and may have diverse origins. Three are imports or close derivatives of styles coming from two opposite directions. Trecastell and Castell Coch no 2 are of Irish styles, while Glaney Wood has close matches on the Continent (Cat. Nos 1-2, 10). The Dolfrwynog halberd (Cat. No. 3) may be of Irish style - matching Type Lough Gur fairly closely - but its unusually narrow midrib could suggest production outside the core area a conclusion supported by the fact that it is made of 'BB-metal' (Needham 2002) which is rare to nonexistent in Irish early metalwork. There are even grounds for wondering whether the Trecastell halberd might have been manufactured outside of Ireland (above). Only the two classified as Type Pontrhydygroes, characterised by strongly outsplayed midribs 
and three rivets set in a rather shallow triangle (Cat. Nos 25-6; Fig. 23d), stand out as being regionally specific. Nevertheless, one of the two halberds

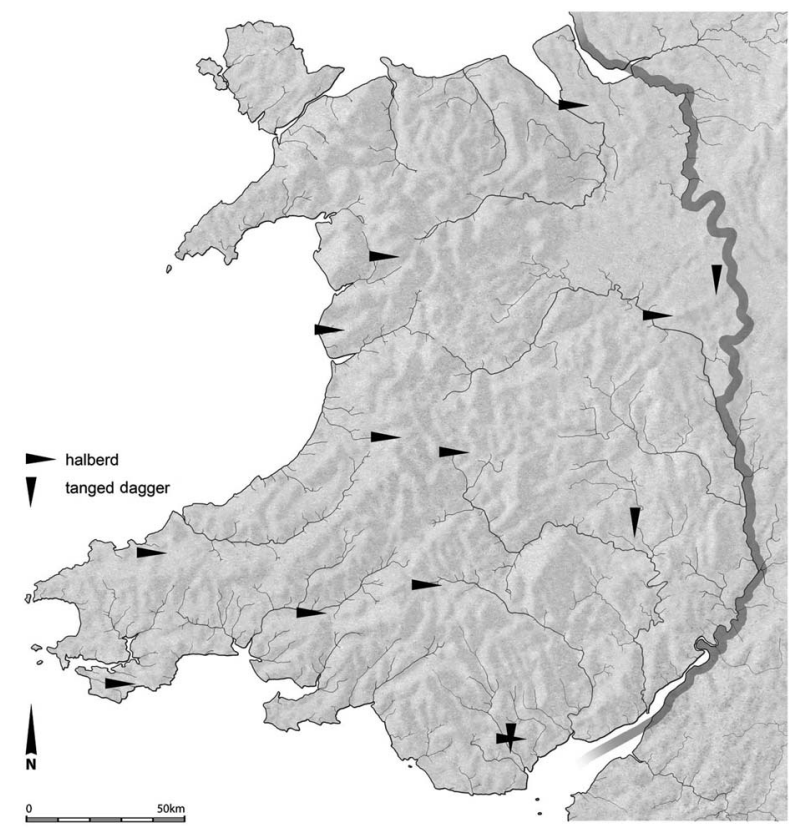

Fig. 34.

Map of recovery for copper halberds and daggers in Wales and the Marches; drawing: Tony Daly, AC-NMW from Tonfannau Quarry, no. 2 (Cat. No. 42), although best conforming to Type Sluie, is alone in that type in only having three rivets and this may reflect local preferences given the predominance of three-rivet over four-rivet formations (nine halberds compared to four or five including the putative first phase of Castell Coch 1; Table 4). If Tonfannau Quarry 2 was produced locally, so too might have been others of Type Sluie even though most of the parallels come from northern Britain. Likewise, the two Pistill Dewy halberds from the region are just as likely to have been locally manufactured as imported; elsewhere just two or three examples from Scotland are known. Type Lambeth is equally equivocal; besides the Shotton halberd (Cat. No. 23; Fig. 23f), the only other is from the Lower Thames Valley (River Thames at Lambeth; Cat. No. 22), a region perhaps unlikely to have produced halberds given that this is the only secure find; another halberd is only vaguely attributed to the River Thames (Cat. No. 14). Moreover, the reworked phase of halberd no 1 from Castell Coch has a hafting-plate that may have been shaped to mimic Type Lambeth with a sinuous butt-line and three rivets. Reconstruction of its original form gives a weapon not quite matched amongst either Type Sluie or Auchingoul halberds (Fig. 36, cf Fig. 23g \& i); this too could be a relatively local product.

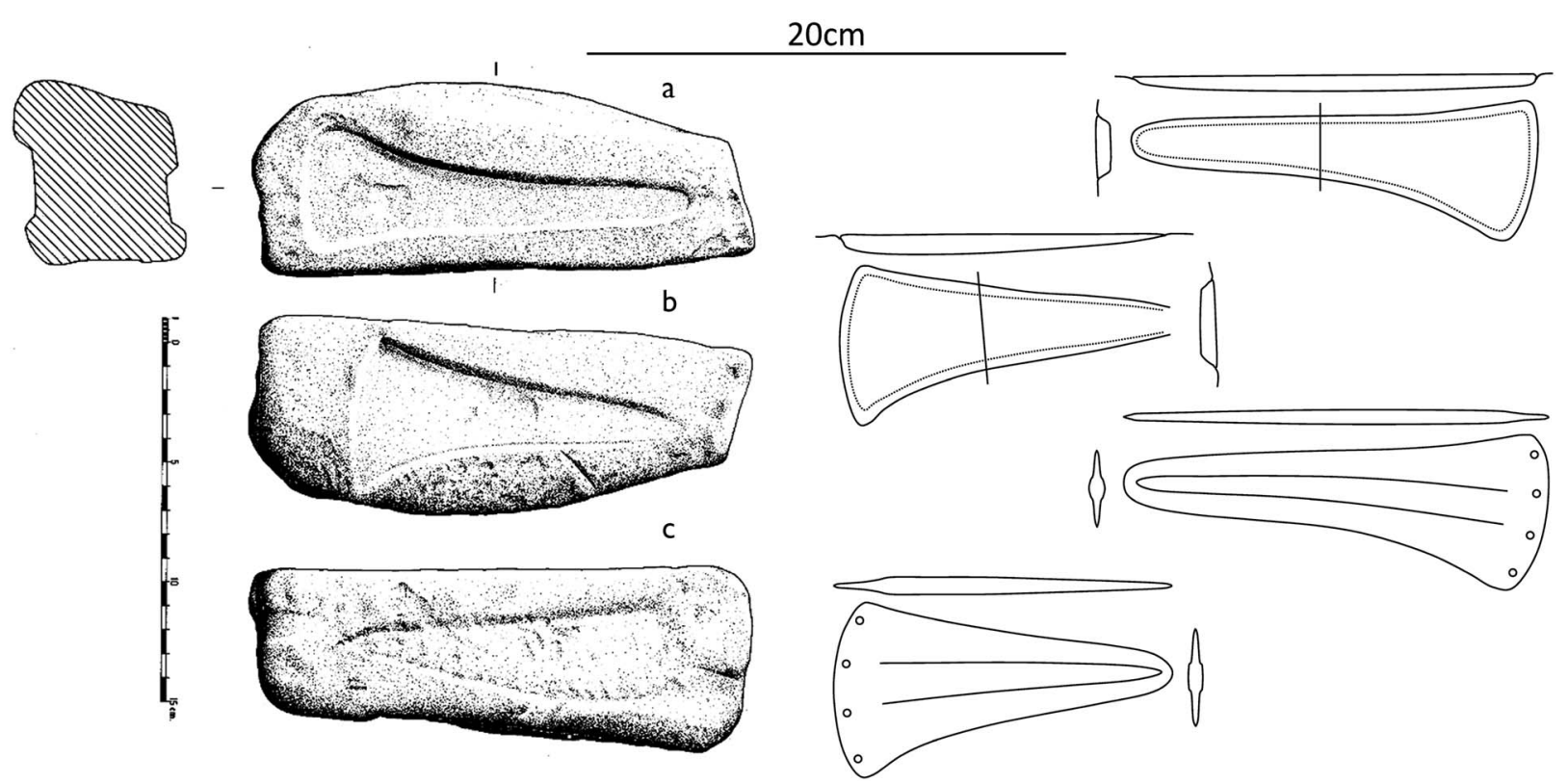

Fig. 35.

Stone univalve mould block from New Mills, Powys, with reconstructions of the blanks cast in the two completed matrices and possible halberd forms produced after post-cast working; scale 25\%; drawings: mould from Green 1985; rest, Stuart Needham 
S. Needham. EMERGENCE AND CONTEXTUALISATION OF HALBERDS IN WALES \& NW EUROPE

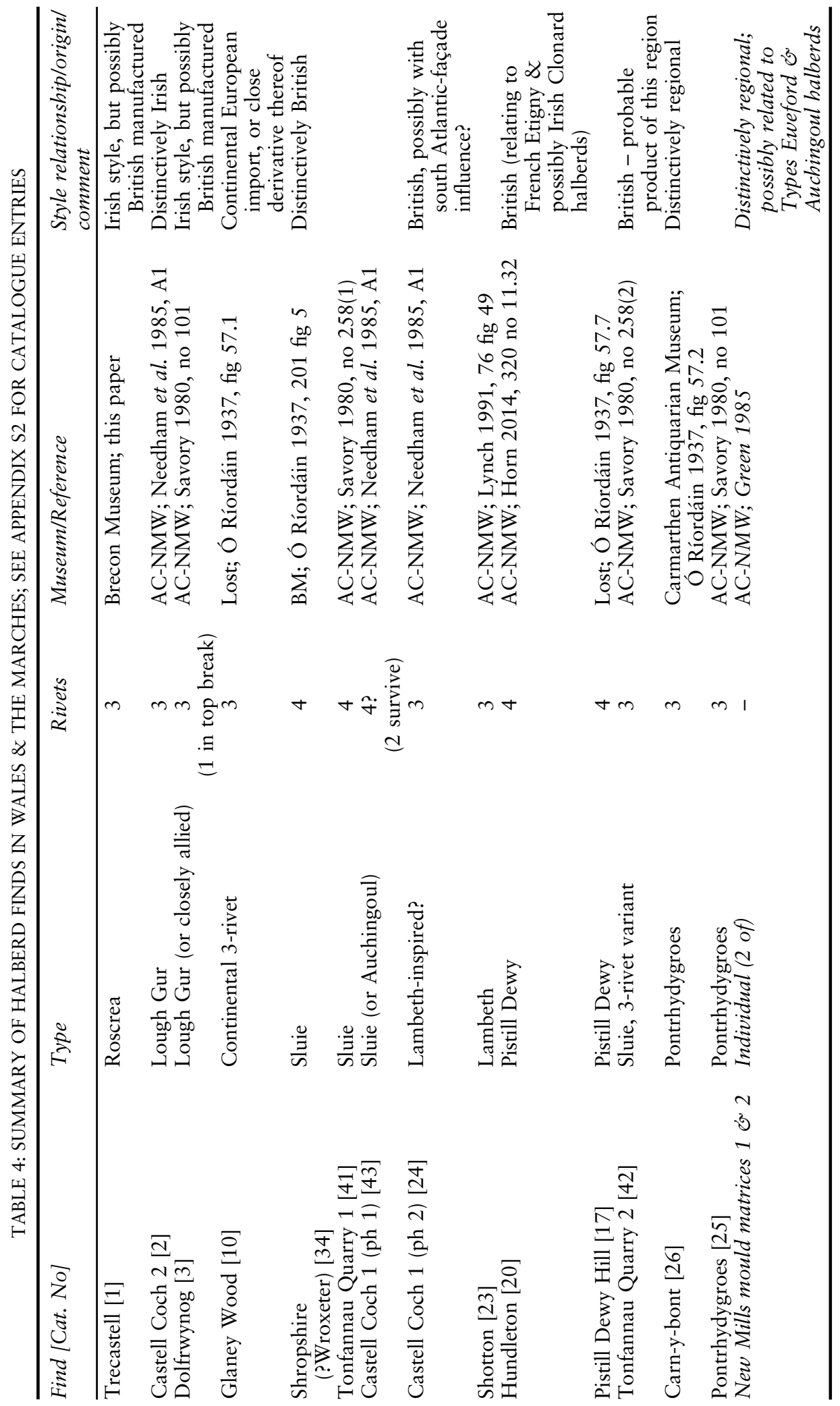




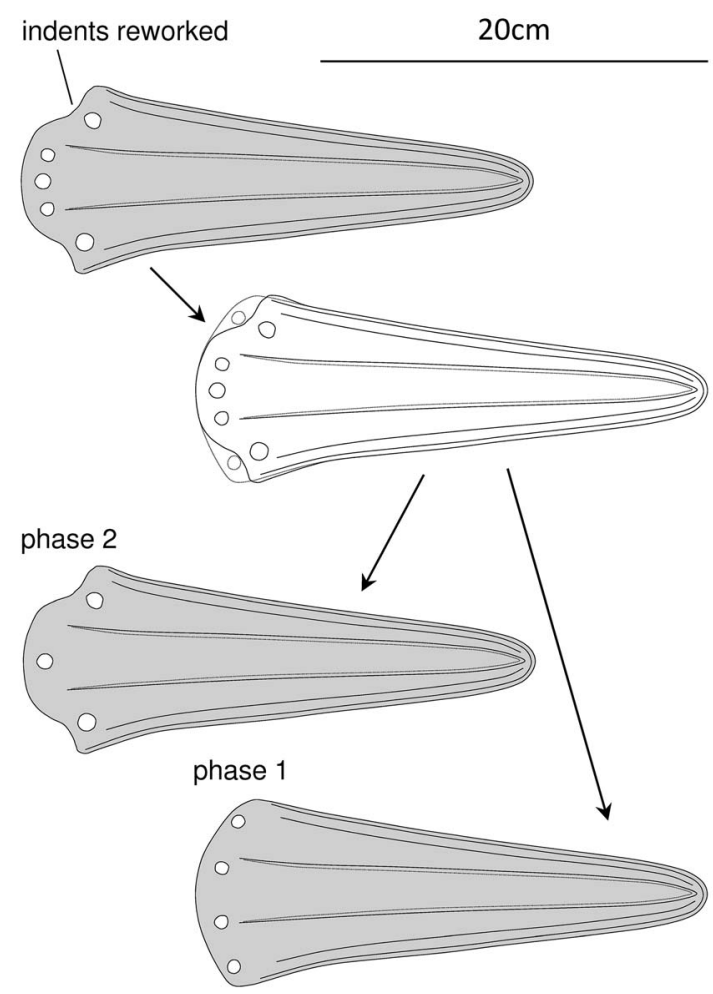

Fig. 36.

Halberd no. 1 from the Castell Coch hoard with a possible reconstruction of its original form; scale $20 \%$; drawing: Stuart Needham

It is clear therefore that regional eclecticism cannot be attributed simply to a pattern of importation from a variety of external halberd production zones. Wales and the Marches are not alone in having an eclectic halberd assemblage (eg, Ó Ríordáin 1937), and this may instead be a case of more transient styles resulting from a high-flux environment for idea exchange in this sphere of production and demand. This may help make sense of the fact that early imports such as Trecastell and, possibly, Glaney Wood, although presumably important in terms of establishing the halberd idea in the region, did not set an enduring template for subsequent halberds.

Despite their diversity, the halberds of Wales and the Marches attest to a commonly held value which was evidently limited in its temporal span and geographic extent. The halberd finds could be taken to imply coherence in certain depositional customs and, therefore perhaps, in broader social and ritual

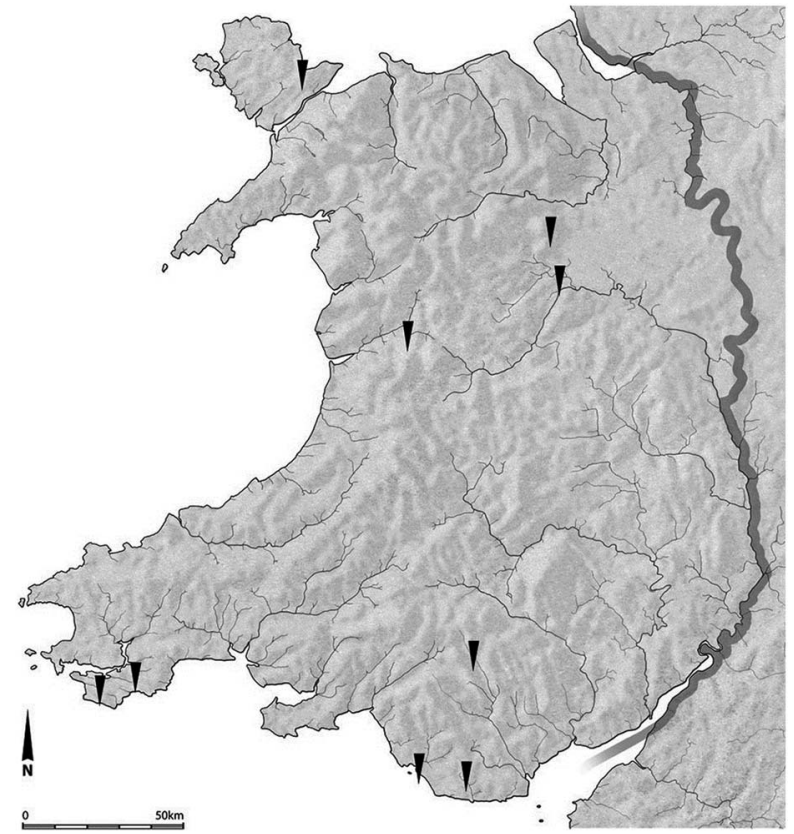

Fig. 37.

Map of recovery for Period 2 daggers (earliest bronze flat daggers); drawing: Tony Daly, AC-NMW

attitudes as far east as the River Dee, mid-Shropshire, and the Vale of Glamorgan (Fig. 34). In the Chalcolithic, the deposition of halberds and the furnishing of graves with copper daggers or knives seem to be largely exclusive of one another on a broad geographical stage (Needham, in prep.). The Wales/Marches region fits this pattern; the only dagger grave known is from its eastern boundary at Wellington Quarry, Herefordshire (Harrison et al. 1999), while two further copper dagger finds also occur along this eastern edge (Fig. 34). This high degree of mutual exclusivity breaks down at the beginning of Period 2 when bronze metallurgy was superseding copper. Suddenly, dagger graves, now with bronze daggers, occur much more widely. In the study-region nine daggers, mostly recorded from burials, occur dotted around the Cambrian massif; they stretch from Anglesey to the Vale of Glamorgan and from east to west (Fig. 37). The demise of the halberd seems to coincide with and was probably a direct consequence of the progressive acceptance of daggers as the premier status symbol for senior male leaders.

Although it is apparent that halberds in the Welsh Chalcolithic help define a particular identity and thus perhaps a territory, it is not easy to define closely a 


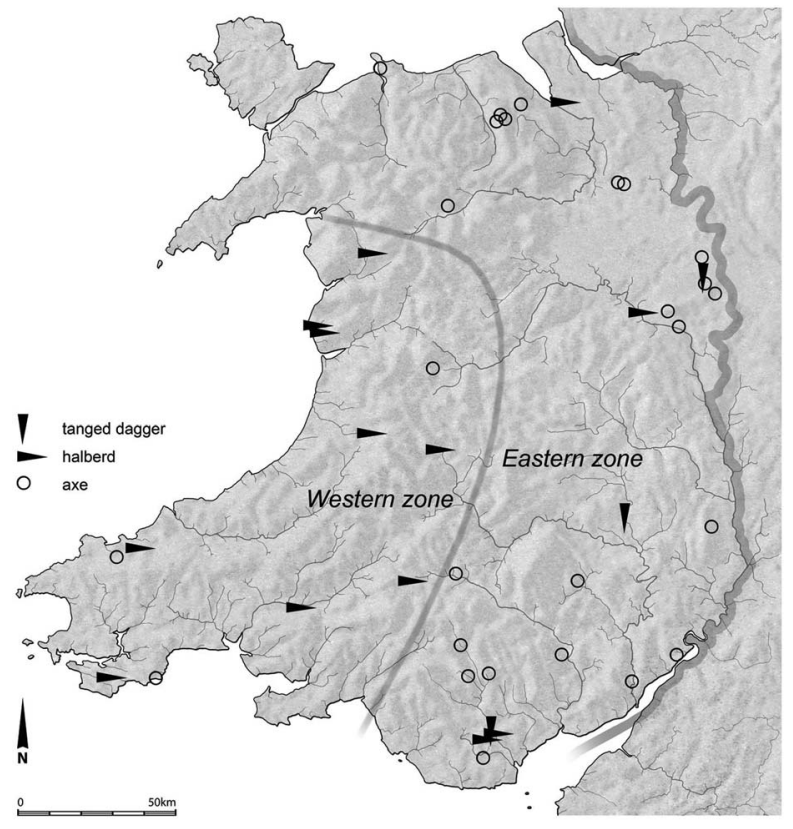

Fig. 38.

Map of recovery for Period 1 (Chalcolithic; Moel Arthur assemblage) metalwork in Wales \& the Marches: halberds, axes, and daggers. The division between a western and eastern zone is to facilitate analysis (see discussion); drawing: Tony Daly, AC-NMW

boundary because the number of finds is still not large. Other contemporary material may help. Copper axes are surprisingly sparse in the west of the region, but occur in fair numbers in a broad swathe to the east. A 'western zone', as defined by the line in Figure 38, has yielded nine halberds and only three axes, whereas the 'eastern zone' has yielded 23 axes, three daggers, and only four halberds. In proportional terms halberds represent $75 \%$ of finds in the west and only $13.3 \%$ of those in the east. There were clearly very different preferences in terms of metalwork types deposited in the east to those in the west. This simple boundary facilitates analysis but need not be historically accurate. Indeed, a more convoluted boundary could well intensify the regional contrast - there are no copper finds in a large area of the central Marches with the exception of the Shropshire halberd (its provenance to 'Wroxeter' is questionable; Chitty 1928), nor west of the Taff valley in the south where lies the Castell Coch hoard; meanwhile Shotton, at the head of the Dee estuary, is effectively a coastal location. Neither should the possibility of blurring from boundary shifts during the course of the Chalcolithic be overlooked.

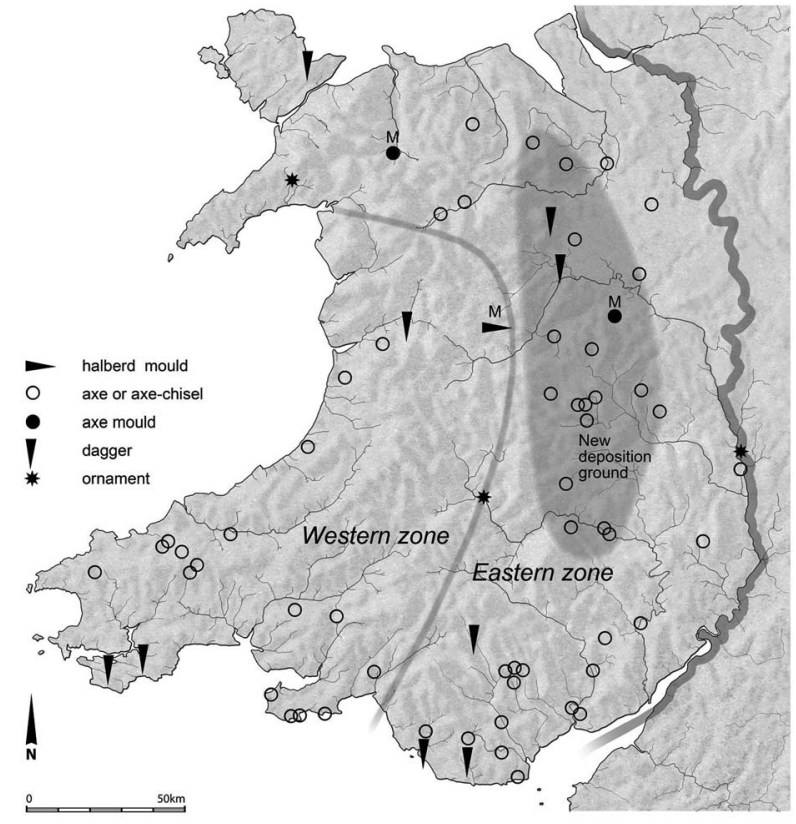

Fig. 39.

Map of recovery for Period 2 metalwork (Brithdir \& Mile Cross assemblages) in Wales \& the Marches: halberd mould, axes, axe-chisels, daggers, and ornaments. No Period 1 finds are yet known from the area highlighted by tone; drawing: Tony Daly, AC-NMW

This marked dichotomy in deposition preference changes at the beginning of Period 2 (c. 2200/2150 BC). With the rapid demise of halberds and the more general deposition of daggers a more uniform deposition regime came into being, although some regions are surprisingly sparse in finds of any kind (Fig. 39). There is, however, another striking change from the previous period: the depositional 'colonisation' of a large area of the central Marches - hill country on the east flank of the Cambrian massif. The toned zone indicated in Figure 39 has yielded as many as 20 finds of Period 2 metalwork in an area that was blank for the preceding period. As always with material that stems predominantly from deliberate deposition, we are caught in an interpretative dilemma; are we observing a phenomenon connected solely with the terminal stage of the use-cycle - i.e. deposition - or could it also reflect changed circumstances in the cycle itself - perhaps even going right back to production? Evidence relating to production is very thin; only one mould find is known, that from the Walleybourne Brook, Shropshire (Thomas 1972), but the character of its products may be instructive. The matrices in this mould would probably have cast Class 


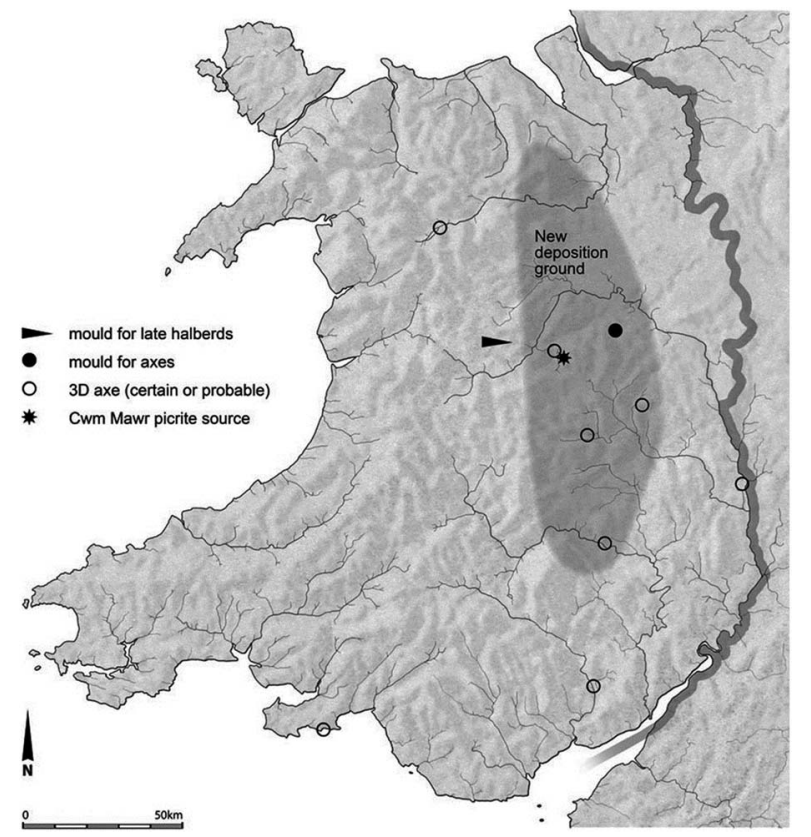

Fig. 40.

Map of recovery for Class 3D axes and the Walleybourne Brook mould in relation to the Period 2 new deposition ground; the source of Group XII rock (picrite) used for

battle-axes and axe-hammers is also shown; drawing: Tony Daly, AC-NMW

3D axes, eight certain or probable examples of which are known from the Marches (Needham et al. forthcoming, appx 1), with just two occurring further west (Fig. 40) and this at least forms a potential bridge between a primary output of local production and the preferred choice of ritual deposition.

The new phenomenon in this region must imply a dramatically enhanced supply of metal for ultimate consumption; this could have been in the form of ready-made objects and it does not necessarily follow that internal production was on a greater scale than elsewhere. Permanent deposition of disposable wealth over any extended period, such as the two-century duration of Period 2, depends crucially on successful replenishment and this could well mean that during this phase the western central Marches had established particular socio-political networks that assured a goodly share of circulating metal.

Although manifest through metalwork deposits, the success of the western central Marches may also have been connected to another material altogether. With the adoption in Britain of stone battle-axes and axe-hammers at the beginning of Period 2, we see the new (or sometimes revived) exploitation of selected rock sources. One favoured rock was picrite from 'Cwm Mawr', near Hyssington, Powys (Shotton et al. 1951; Jones \& Burrow 2011), a site that lies in the heart of the 'new deposition ground' (Fig. 40). As a culturally valuable resource, picrite products could have contributed to the development of a new economic and cultural vibrancy. Unsurprisingly perhaps, there is also a concentration of those products themselves in the heart of the 'new deposition ground' (Clough \& Cummins 1988, 275 map 11).

The appearance of the 'new deposition ground' is the more striking because of the lacuna in the previous phase, begging questions as to what that lacuna represents. We cannot at present know whether this zone leaned towards western or eastern attitudes in the Chalcolithic, but those attitudes rubbed up against one another somewhere around this region and the subsequent 'deposition colonisation' could be interpreted as the outcome of a successful 'campaign' waged against the halberd-using societies of the higher mountain spine and perhaps its eastern flanks. In this context it is worth noting that the only evidence for continuing, post-Chalcolithic interest in halberds is the New Mills mould, located in the heart of Wales, just a little west of the new deposition ground (Fig. 39).

Ideological and physical confrontation, or perhaps accommodation, might also be suspected elsewhere. Towards the end of the Chalcolithic a halberd hoard was deposited in the Taff gorge at Castell Coch. Axe finds to north and south could again suggest a cultural meeting zone in this area of the Taff and the mountains to the north. It is, however, the contextual evidence from Trecastell still further north that provides the better platform for interpretation. One of the two large internal pits, potentially graves, certainly preceded halberd deposition and dating evidence for the other pit and the ring-ditch is consistent (Griffiths in Cotswold Archaeology 2014). The most obvious interpretation then is that this was initially an early Beaker-style burial site, but that it represented a pioneering foray that did not become well established during the course of the Chalcolithic. Although early styles of Beaker are extremely rare in Wales and the Marches (Lynch 2000, 115), four examples are spread across the south-east corner of our study zone, from Herefordshire through the Brecon Beacons to the Vale of Glamorgan. The ring-ditch at Trecastell could lie near the north-west limit of this pioneering-period 


\section{S. Needham. EMERGENCE AND CONTEXTUALISATION OF HALBERDS IN WALES \& NW EUROPE}

Beaker enclave. The subsequent act of deposition of a halberd at the centre of the ring-ditch, could well represent a 'trumping' or emasculation of the site's former cultural significance by a society who held a radically different world view. The strategic importance of the interfluve between the Usk and Towi valleys could well be relevant. These are speculative connections and ideas, but they deserve to be examined further as new evidence is amassed.

\section{CONCLUSIONS}

The survival of the haft-grip on the Trecastell halberd is of tremendous importance, especially since there is now doubt about the fidelity of the Carn haft copy. It provides the first clear evidence for how hafts were fitted to halberd heads in Britain and Ireland. It also shows that the shaping of the wood and the securing of the haft could contribute to the style of the fully mounted object.

Despite its poor condition, identification of the metal head to type is relatively secure. The halberd belongs to a specifically Irish type of squat proportions which has been defined as Type Roscrea. An early dating within the overall halberd sequence is highly likely and it is possible that this was one of the earliest of the weapon class to be in use in Wales and indeed Britain. Nevertheless, neither this nor other potentially early imports set a style-template for the development of halberds in the region. Instead, a more complex mix of styles emerged during the course of the mid- to late Chalcolithic involving stylistic inputs from across the Irish Sea (Types Clonard and Lough Gur), from northern France (Type Etigny) and even perhaps more distantly, from the southern end of the Atlantic façade (Type Baútas).

It is salutary that recognition of the importance of squat halberds is a partial return to Ó Ríordáin's classification of nearly 80 years ago. He had recognised not only the Clonard type (as later named by Harbison (1969)), but also the Roscrea type (as named here). Types Clonard and Roscrea account for three of Ó Ríordáin's (types 1-3), but his remaining three are far less satisfactory. One possible reason for this shift from successful morphological groupings to unsatisfactory ones is that, sub-consciously or otherwise, Ó Ríordáin was seeking a unilinear evolution to explain virtually all Irish and, by implication, British halberds. New evaluation instead suggests a multi-linear evolution (Figs 31 \& 33).

Improved chronological structures have the potential to give us new insights into the relative independence, at the stylistic level, of major regional halberd groups such as the Argaric, Aunjetitz, Italian, and Irish series - and we can now add the definitive recognition of a British style group. They also give prospects for identifying some general but instructive trends in spatial and temporal patterning. In Italy, for example, over the course of over a millennium the preferred hafting-plate format changed from a rather shallow form (Remedello/Rinaldone halberds onwards) to a significantly deeper one (Type Cotronei). This is exactly the opposite of the trend in north-western Europe. Iberia may not be so clear cut, but again the shallow and well-expanded hafting-plates of Argaric types are largely later than the Atlantic halberd styles with their deeper hafting-plate formats.

Noteworthy trends can be seen in the spatial dimension too. Amongst the 'Atlantic' style continuum that can be pieced together all the way from Iberia to Scandinavia, the preferred number of rivets varies. The great majority in Iberia have just three rivets, perhaps reflecting origins in the slightly earlier, but shallowerbutted 'Mediterranean' types. Although three rivets are still in the majority in France, we begin to see a significant minority of four-rivet halberds and this proportion increases substantially in Britain, where four-rivet forms are at their zenith. Nevertheless, these run in parallel with three-rivet and occasional fiverivet halberds, and the same is true in Ireland where the balance tips back again towards the dominant choice of three rivets.

A key conceptual issue raised earlier in this paper concerns the way in which we might envisage the halberd idea to have spread and suggests we should differentiate between low-level halberd circulation ('undercurrent') and the vigorous, but non-synchronous 'uptake' of the halberd as a cultural emblem in certain zones. Other issues of wider relevance are how we treat the classification of halberds and how we interpret typological relationships between them. For a long time halberds seemed to have a short currency relative to, say, axes, dagger-like weapons or spearheads, and this has probably sub-consciously drawn researchers to seek significant connections throughout the object class, wherever it occurred. At times the links made were based on rather limited morphological evidence thereby potentially giving a false sense of reinforcement to the belief in a restricted halberd horizon. Now that it has become clear that halberds, taken in aggregate across Europe, have a currency of one and a half millennia or more, perceptions need to be adjusted. Drawing a 
parallel with socketed axes, for example, the presence of horizontal mouth mouldings would hardly in isolation be seen to justify specific links between one regional group and another. This does not mean we should not attempt to distil genuine style connections amongst halberds, but we now need to proceed from everimproving chronologies towards the assessment of connections, rather than vice versa. Only where there are recurring sets of features or remarkable individual features unlikely to recur independently might it still be reasonable to deduce some level of contact and contemporaneity directly from raw typological comparison. Moreover, for different reasons both low-level circulation as part of the undercurrent and intensive feature exchange between regions of uptake will predictably give rise to many individual halberds which need not be recognisable as belonging to a conventionally defined type.

Acknowledgements: The analysis and reporting on the Trecastell halberd was commissioned by Cotswold Archaeology as part of a programme of work undertaken for Rhead Group on behalf of National Grid. The site was excavated by Cotswold Archaeology. We are very grateful to all those bodies for permission to make use of parts of the original report, including photographic images commissioned for the same purpose. Particular assistance has been received from Karen Walker, Linda Bonnor, and Jon Hart at Cotswold Archaeology.

Those illustrations not by the principal author are the work of Tony Daly, Amgueddfa Cymru-National Museum Wales, and Daniel Bashford, Cotswold Archaeology. Likewise, photographs not by the author are owed to Robin Maggs, Amgueddfa Cymru-National Museum Wales. Rob Banbury is also thanked for advice in relation to publishable illustrations.

The extensive review of insular halberds required to contextualise the Trecastell find could not have been possible without the unfailing assistance of curators in charge of the main relevant collections: Mary Cahill, National Museum of Ireland, Dublin; Trevor Cowie, National Museums Scotland, Edinburgh; Neil Wilkin, British Museum; Adam Gwilt, Amgueddfa Cymru-National Museum Wales, Cardiff; Alison Roberts, Ashmolean Museum, Oxford; and, in earlier times, the late Lawrence Flanagan, Ulster Museum, Belfast. Gratitude is also extended to Joanne Turner at Dumfries Museum, Caroline McDonald at the Museum of London and Gavin Evans at Carmarthen County Museum. As will be clear from the named contributors, other aspects of this project were only possible as a joint effort with staff at Amgueddfa Cymru-National Museum Wales and the Portable Antiquities Scheme; Stuart Needham is particularly grateful to Adam Gwilt for his inputs.

Christian Horn is thanked for sight of an unpublished draft which helped shape the undercurrent idea presented here, though the detailed formulation is the writer's. Thanks for various information go to David Bell, Dirk Brandherm,
Peter Bray, Henri Gandois, Seren Griffiths, Rowena Gale, Peter Northover, Brendan O'Connor, \& Greer Ramsey. The referees' comments naturally improved the paper.

The Trecastell halberd is to be accessed into the collections of Brecknock Museum \& Art Gallery, (Brecon).

\section{ONLINE SUPPLEMENTARY MATERIAL}

Appendix S1: The classification of halberds from Britain and Ireland

Appendix S2: Summary list of halberds from Britain with key details and dimensions

Appendix S3: Summary list of halberds from Ireland with key details and dimensions

Appendix S4: Summary of associations for Irish and British halberds

Appendix S5: Halberds used for the type-series in Figures $22 \& 23$

Appendix S6: Bibliography relating to the Appendices

To view supplementary material for this article, please visit http://dx.doi.org/10.1017/ppr.2015.8

\section{BIBLIOGRAPHY}

Abélanet, J. 1986. Signes sans Paroles: Cent Siècles d'Art Rupestre en Europe Occidentale. Poitiers: Hachette

Bell, D. 2014. A radiocarbon date for an Irish Bronze Age halberd. PAST 76, 15-6

Bianco Peroni, V. 1994. I Pugnali nell'Italia Continentale. Prähistorische Bronzefunde VI, 10. Stuttgart: Franz Steiner

Brandherm, D. 2003. Die Dolche und Stabdolche der Steinkupfer- und der älteren Bronzezeit auf der Iberischen Halbinsel. Prähistorische Bronzefunde VI, 12. Stuttgart: Franz Steiner

Brandherm, D. 2004. Porteurs de hallebardes? Überlegungen zur Herkunft, Entwicklung und Funktion der bronzezeitlichen Stabklingen. Varia Neolithica 3, 279-334

Butler, J.J. 1963. Bronze Age connections across the North Sea: a study in prehistoric trade and industrial relations between the British Isles, the Netherlands, north Germany and Scandinavia, c. 1700-700 вс. Palaeohistoria 9

Case, H.J. 1966. Were Beaker people the first metallurgists in Ireland? Palaeohistoria 12, 141-77

Chernorkian, R. 1988. Les Armes Métalliques dans l'Art Protohistoriques de l'Occident Mediterranean. Paris: CNRS

Chitty, L.F. 1928. Bronze halberd said to have been found in Shropshire. Archaeologia Cambrensis 83, 209-11

Clough, T.H. McK \& Cummins, W.A. (eds). 1988. Stone Axe Studies: the petrology of prehistoric stone implements from the British Isles, Volume 2. London: Council for British Archaeology, Research Report 67 


\section{S. Needham. EMERGENCE AND CONTEXTUALISATION OF HALbERDS IN WALES \& NW EUROPE}

Coffey, G. 1901. Irish copper celts. Journal of the Anthropological Institute 31, 265-79

Coffey, G. 1908-9. Irish copper halberds. Proceedings of the Royal Irish Academy 27C, 94-114

Coghlan, H.H., Butler, J.R. \& Parker, G. 1963. Ores and Metals: a report of the Ancient Mining and Metallurgy Committee. London: Royal Anthropological Institute

Coles, J.M. 1968-9. Scottish Early Bronze Age metalwork. Proceedings of the Society of Antiquaries of Scotland 101, $1-110$

Cordier, G. 2009. Une nouvelle hallebarde du Bronze ancien sur la Loire (Avoine, Indre-et-Loire). Bulletin Préhistoire $d u$ Sud-Ouest 17, 243-5

Cotswold Archaeology (CA). 2014. South Wales Pipeline Project Site 38.17, Land North of Llwyn-Meurig, Trecastle, Powys: Archaeological Excavation. CA: Unpublished typescript report 13315

Day, R. 1892. On copper implements found in the King's County. Journal of the Cork Historical \& Archaeological Society 1, 94-5

Despriée, J. 1983. Circonscription du Centre. Gallia Préhistoire 26, 249-81

Gallay, G. 1981. Die Kupfer- und Altbronzezeitlichen Dolche und Stabdolche in Frankreich. Prähistorische Bronzefunde VI, 5. Munich: Beck'sche

Gebers, W. 1978. Endneolithikum und Frühbronzezeit im Mittelrheingebiet: Katalog. Saarbrücker Beiträge zur Altertumskunde 28

Gedl, M. 1980. Die Dolche und Stabdolche in Polen, Prähistorische Bronzefunde VI, 4. Munich: Beck'sche

Green, H.S. 1985. A Bronze Age stone mould from New Mills, Newtown, Powys. Bulletin of the Board of Celtic Studies 32, 273-4

Harbison, P. 1969. The Daggers and Halberds of the Early Bronze Age in Ireland, Prähistorische Bronzefunde VI, 1. Munich: Beck'sche

Harrison, R.J., Jackson, R. \& Napthan, M. 1999. A rich Bell Beaker burial from Wellington Quarry, Marden, Herefordshire. Oxford Journal of Archaeology 18, $1-16$

Hemans 1847-50. Untitled communication. Proceedings of the Royal Irish Academy 4, 565-6

Horn, C. 2014. Studien zu den Europäischen Stabdolche. Berlin: Instut für Prähistorische Archäologie der Freien Universität; Universitätsforschungen zur Prähistorischen Archäologie, Band 246

Jones, N.W. \& Burrow, S. 2011. A potential axe factory near Hyssington, Powys: survey and excavation 2007-08. In V. Davis \& M. Edmonds (eds) Stone Axe Studies III, 295-307. Oxford: Oxbow Books

Junghans, S., Sangmeister, E. \& Schröder, M. 1968. Kupfer und Bronze in der frühen Metallzeit Europas. Berlin: Studien zu den Anfangen der Metallurgie 2

Kemble, J.M. 1863. Horae Ferales; or Studies in the Archaeology of the Northern Nations. London: Lovell Reeve

Lelong, O. \& MacGregor, G. 2007. The Lands of Ancient Lothian: interpreting the archaeology of the A1. Edinburgh: Society of Antiquaries of Scotland
Lenerz-de Wilde, M. 1991. Überlegungen zur Funktion der frühbronzezeitlichen Stabdolche. Germania 69, 25-48

Lynch, F. 1991. Prehistoric Anglesey: the archaeology of the island to the Roman Conquest, 2 edn. Llangefni: Anglesey Antiquarian Society

Lynch, F. 2000. The later Neolithic and the earlier Bronze Age. In F. Lynch, S. Aldhouse-Green \& J.L. Davies, Prehistoric Wales, 79-138. Stroud: Sutton

Needham, S. 2002. Analytical implications for Beaker metallurgy in north-west Europe. In M. Bartelheim, E. Pernicka \& R. Krause (eds), Die Anfänge der Metallurgie in der Alten Welt, 99-133. Freiberg: Forschungen zur Archäometrie und Altertumswissenschaft 1

Needham, S. 2004. Migdale-Marnoch: sunburst of Scottish metallurgy. In I.A. Shepherd \& G.J. Barclay (eds), Scotland in Ancient Europe: The Neolithic and Early Bronze Age of Scotland in their European context, 217-45. Edinburgh: Society of Antiquaries of Scotland

Needham, S. 2012. Case and place for the British Chalcolithic. In M.J. Allen, J. Gardiner \& A. Sheridan (eds), Is There a British Chalcolithic: people, place and polity in the later third millennium, 1-26. Oxford: Prehistoric Society Research Papers 4

Needham, S. forthcoming. The halberd and its haft remains; Trecastell, and the halberds of Britain, Ireland and the near continent. http:/www.cofiadurcahcymru.org.uk/

Needham, S., Gwilt, A., Lodwick, M., Northover, P. \& Reavill, P. forthcoming. Halberds and early metalwork in Wales and the Marches. http://www.cofiadurcahcymru. org.uk/

Needham, S. \& Cowie, T. 2012. The halberd pillar at Ri Cruin cairn, Kilmartin, Argyll. In A. Cochrane \& A.M. Jones (eds), Visualising the Neolithic: abstraction, figuration, performance, representation, 89-110. Oxford: Neolithic Studies Group Seminar Papers 13

Needham, S.P., Lawson, A.J. \& Green, H.S. 1985. Early Bronze Age Hoards. London: British Bronze Age Metalwork, Associated Finds Series A1-6

Northover, J.P. 1999. The earliest metalworking in southern Britain. In A. Hauptmann, E. Pernicka, T. Rehren \& Ü. Yalçïn (eds), The Beginnings of Metallurgy: proceedings of the international conference, Bochum, 1995, 211-25. Bochum: Der Anschnitt, Beiheft 9

O'Brien, W. 2004. Ross Island: mining, metal and society in early Ireland. Galway: National University of Ireland, Bronze Age Studies 6

O'Flaherty, R. 1998. The Early Bronze Age halberd: a history of research and a brief guide to the sources. Journal of the Royal Society of Antiquaries of Ireland 128, 74-94

O'Flaherty, R. 2002. A Consideration of the Early Bronze Age Halberd in Ireland. Unpublished doctoral thesis, University College, Dublin

O'Flaherty, R. 2007. A weapon of choice - experiments with a replica Irish Early Bronze Age halberd. Antiquity 81, 423-34

Ó Ríordáin, S. 1937. The halberd in prehistoric Europe: a study in prehistoric origins, evolution, distribution, and chronology. Archaeologia 86, 195-321 
Raftery, J. 1942. A bronze halberd from Carn, Co. Mayo. Journal of the Galway Archaeological of Historical Society 20, 54-6

Savory, H.N. 1980. Guide Catalogue of the Bronze Age Collections. Cardiff: National Museum of Wales

Schubart, H. 1973. Las alarbardas tipo Montejícar. In J. Maluquer de Motes (ed.), Estudios Dedicados al Profesor, Dr. Luis Pericot, 247-69. Barcelona: Universidad de Barcelona, Instituto de Arqueología y Prehistoria, Publicaciones Eventuales 23

Schuhmacher, T.X. 2002. Some remarks on the origin and chronology of halberds in Europe. Oxford Journal of Archaeology 21, 263-88

Shotton, F.W., Chitty, L.F. \& Seaby, W.A. 1951. A new centre of stone axe dispersal on the Welsh border. Proceedings of the Prehistoric Society 17, 159-67
Thomas, N. 1972. An Early Bronze Age stone axe-mould from the Walleybourne below Longden Common, Shropshire. In F. Lynch \& C. Burgess (eds), Prehistoric Man in Wales and the West: essays in honour of Lily Chitty, 161-6. Bath: Adams \& Dart

Timoney, M. 1970. A halberd from Clounloum Bog, Co. Clare. North Munster Antiquarian Journal 13, 3-5

Vandkilde, H. 1996. From Stone to Bronze: the metalwork of the Late Neolithic and earliest Bronze Age in Denmark. Aarhus: Jutland Archaeological Society

Wüstemann, H. 1995. Die Dolche und Stabdolche in Ostdeutschland, Prähistorische Bronzefunde VI, 8. Stuttgart: Franz Steiner

\section{RÉSUMÉ}

Hallebarde emmanchée excavée à Trecastell, Powys: d'un courant sous-jacent à un captage: émergence et contextualisation des hallebardes au Pays de Galles et dans l'Europe du nord-ouest, de Stuart Needham

En 2007 des excavations à Trecastell, Powys, sud du Pays de Galles, ont révélé une hallebarde de cuivre entière avec son manche, ce qui a des implications majeures pour la manière dont on emmanchait les hallebardes, mais la découverte nous a aussi incités à reconsidérer les hallebardes insulaires dans leur contexte du nord-ouest de l'Europe. Notre compréhension des relations entre les différents types de hallebardes et les différents groupes régionaux continue à être entravée par la pénurie de témoignages de datations de qualité, mais la création de meilleures classifications des armes britanniques et irlandaises et de nouvelles dates au C14 de deux exemplaires, dont l'un est Trecastell, ont permis de faire avancer un nouveau programme de développement.

Nous considèrons, d'une manière plus générale, l'émergence des hallebardes à tête de métal. Tandis que l'on reconnait que des outils ressemblant à des hallebardes pré-existaient en d'autres matériaux dans certaines parties de l'Europe, nous argumentons que l'apparition des hallebardes à tête de métal dépendait de la transmission d'un ensemble particulier de compétences en métallurgie et autres techniques associées. Un nouveau modèle pour le vigoureux captage des hallebardes sur une base régionale aide à expliquer la distribution inégale et l'anachronisme des points chauds de hallebardes.

L'hallebarde de Trecastell vient s'ajouter à une des importantes concentrations d'armes de ce type en GrandeBretagne et incite à une révision plus générale de la plus ancienne métallurgie du Pays de Galles et des Marches. Quant au chalcolithique, les hallebardes ont un rôle à jouer dans l'identification d'un contraste majeur dans le comportement de dépôt; ce contraste se dissout à l'âge du bronze ancien quand est établi un 'nouveau lieu de dépôt'. Le premier est attribué à l'existence d'un groupe régional, s'étendant sur une grande partie de la région, pour lequel l'hallebarde constituait une icône culturelle, tandis que le dernier pourrait avoir un rapport avec la disparition de cette valeur consacrée de la hallebarde.

\section{ZUSSAMENFASSUNG}

Ein geschäfteter Stabdolch aus Trecastell, Powys: Von Unterströmungen zu Übernabmen - das Auftreten und die Kontextualisierung von Stabdolchen in Wales und Nordwesteuropa, von Stuart Needham

Ausgrabungen in Trecastell, Powys, Südwales, förderten im Jahr 2007 einen kupfernen Stabdolch zusammen mit seiner Schäftung zutage. Diese Entdeckung ist von entscheidender Bedeutung für die Erkenntnisse zu den Schäftungsweisen, vor allem aber hat sie eine Neubewertung der Stabdolche der Inseln in ihrem nordwesteuropäischen Kontext ausgelöst. Das Verständnis für die Beziehungen zwischen verschiedenen Stabdolchtypen und unterschiedlichen regionalen Gruppen wird weiterhin behindert durch den Mangel an guten Datierungen, doch erlauben es zum 


\section{S. Needham. emergence And COnTEXTUAlisation of HalberdS IN WALES \& NW EUROPE}

einen die Verbesserung der Klassifikation britischer und irischer Waffen und zum anderen neue Radiokarbondaten von zwei Fundstücken, davon das eine aus Trecastell, ein neues Entwicklungsschema zu erarbeiten.

In diesem Beitrag wird die Entstehung von Stabdolchen mit metallenem Kopf breit diskutiert. Während akzeptiert wird, dass stabdolchartige Gerätschaften aus anderen Materialien in einigen Teilen Europas bereits zuvor existierten, wird hier argumentiert, dass das Erscheinen von Stabdolchen mit Metallkopf von der Weitervermittlung eines bestimmten Sets an metallurgischem und damit verwandtem Wissen abhing. Ein neues Modell für die intensive Übernahme auf regionaler Basis ermöglicht die Kleinteiligkeit und den Anachronismus von Stabdolch-„Hotspots“ zu erklären.

Der Stabdolch von Trecastell ist einer der bedeutsamen Konzentrationen dieses Waffentyps in Großbritannien zuzurechnen und ist Anlass für eine grundlegende Neubewertung der frühesten Metallbearbeitung in Wales und den Welsh Marches. Für das Chalkolithikum sind die Stabdolche ein zentrales Element um generelle Unterschiede in Deponierungspraktiken zu identifizieren; diese Unterschiede lösen sich am Beginn der Frühbronzezeit auf mit der Etablierung eines „neuen Deponierungsgrunds“. Die ältere Praxis wird der Existenz einer Regionalgruppe in weiten Teilen der Region zugeschrieben, für die der Stabdolch als kultureller Marker diente, während die jüngere Praxis mit dem Niedergang dieses dem Stabdolch eingeschriebenen Wertes in Verbindung stehen kann.

\section{RESUMEN}

La alabarda enmangada excavada en Trecastell, Powys: desde el trasfondo al entendimiento -la emergencia y contextualización de alabardas en Gales y el noroeste de Europa, por Stuart Needham

Las excavaciones desarrolladas en Trecastell, Powys, en el sur de Gales, en 2007 proporcionaron una alabarda de cobre completa con su enmangue. Este descubrimiento tuvo importantes implicaciones acerca del enmangue de las alabardas, pero motivó igualmente un reexamen de las alabardas insulares en el contexto del noroeste de Europa. El esclarecimiento de la relación entre los distintos tipos de alabardas y los diferentes grupos regionales está limitado por la escasez de buenas evidencias cronológicas, pero la creación de mejores clasificaciones de armas para los casos británicos e irlandés y las nuevas dataciones radiocarbónicas obtenidas en dos ejemplos, uno de ellos Trecastell, han permitido un avance considerable en este aspecto.

La aparición de alabardas de cabeza metálica es considerada de un modo más general. Pese a que en algunas partes de Europa se reconoce la pre-existencia de artefactos similares realizados en otros materiales, la aparición de alabardas metálicas requiere la transmisión de un conjunto de conocimientos sobre metalurgia y otras tareas relacionadas. Una comprensión de las alabardas en su contexto regional ofrece una nueva explicación al fragmentario y anacrónico problema de las alabardas.

La alabarda de Trecastell se suma a una de las concentraciones más significativas de este tipo de armas en Gran Bretaña y promueve una visión general de la primera metalurgia en Gales y Marches. Durante el Calcolítico, las alabardas sirven como principal elemento de contraste entre distintos comportamientos de deposición; este contraste se diluye a inicios del Bronce Antiguo, cuando se establece un nuevo esquema. El primero se atribuye a la existencia de un grupo a lo largo de la región, para quien la alabarda sirve de icono cultural, mientras que el segundo podría relacionarse con la pérdida del valor sacralizado de las alabardas. 